$* * * * * * * * * * * * * * * * * * * * * * * * * * * * * * * * * * * * * * * * * * * * * * * * * * * * * * * * * * * * * * * * * * * * * * * * * * * * * * * * * *$

This manuscript has been submitted for publication in TECTONOPHYSICS. Please note that it has yet to be formally accepted for publication. Subsequent versions of this manuscript may have slightly different content. If accepted, the final version of this manuscript will be available via the 'Peer-reviewed Publication DOI' link on the righthand side of this webpage.

$* * * * * * * * * * * * * * * * * * * * * * * * * * * * * * * * * * * * * * * * * * * * * * * * * * * * * * * * * * * * * * * * * * * * * * * * * * *$ 


\title{
Protracted thermal evolution of the Neoproterozoic Araçuaí hot orogen (SE Brazil): consequences for rheology, strain distribution, and deformation analysis
}

\author{
Alain Vauchez ${ }^{1 *}$, Maria Helena B.M. Hollanda ${ }^{2}$, Patrick Monié ${ }^{1}$, Mathieu Mondou ${ }^{1,2}$, \\ Marcos Egydio-Silva ${ }^{2}$ \\ (1) Géosciences Montpellier, Université de Montpellier \& CNRS, Place E. Bataillon, 34095 Montpellier Cedex \\ 05, France

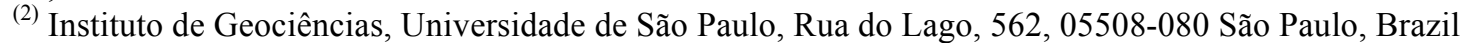

\begin{abstract}
:
The Araçuaí-Ribeira belt formed during the amalgamation of West Gondwana in the late Neoproterozoic. Its evolution encompasses a main tectono-metamorphic peak at $600-580$ Ma and a minor one, associated with the final collision with the Western Congo at 540-530 Ma. This belt holds characteristics of a hot-orogen: high thermal gradient $\left(>30{ }^{\circ} \mathrm{C} / \mathrm{km}\right)$, pervasive partial melting of the middle crust, emplacement of huge volume of magmas resulting from partial melting of the lower crust and underlying mantle, and slow cooling after the peak of temperature. We report 21 new amphibole, biotite and muscovite ${ }^{40} \mathrm{Ar} /{ }^{39} \mathrm{Ar}$ ages, which complement data already published by our group. Altogether, these data support slow cooling (3-4 $\left.{ }^{\circ} \mathrm{C} / \mathrm{Myr}\right)$ during several tens of million years after the peak temperature $\left(\sim 800^{\circ} \mathrm{C}\right.$ at $\left.\sim 600 \mathrm{Ma}\right)$, followed by faster cooling $\left(>10^{\circ} \mathrm{C} / \mathrm{Myr}\right)$ after the final amalgamation of Western Gondwana. We estimate that $\sim 30$ Myr were needed to heat the middle crust to the peak of temperature and that anatectic and plutonic bodies remained in the magmatic state over at least $40 \mathrm{Myr}$. This protracted thermal evolution likely had major effects on the rheology of the middle crust and on the tectonic evolution of this orogen. For instance, correlation of $\mathrm{U}-\mathrm{Pb}$ zircon crystallization ages and ${ }^{40} \mathrm{Ar} /{ }^{39} \mathrm{Ar}$ biotite cooling ages in the anatectic core of the orogen denotes a diachronic thermal evolution likely related to a 3D deformation characterized by successive upwelling of anatectic components, along a channel crosscutting pre-existent fabric (channel-flow type). This study also highlights that classical structural analysis techniques relying on changes in pressure or temperature conditions to identify the succession of deformation phases, cannot be used to decipher the tectonic evolution of hot, slowly cooling orogenic belts, where temperature varies weakly over tens of millipn years, allowing diachronic episodes of deformation to occur under almost similar pressure and temperature conditions.
\end{abstract}

* Corresponding author - email address: alain.vauchez@umontpellier.fr 
37 Keywords: Hot orogen, ${ }^{40} \mathrm{Ar} /{ }^{39} \mathrm{Ar}$ ages, slow cooling, crust rheology, gravity-induced 3D deformation.

1) Slow cooling of the Neoproterozoic Araçuaí hot orogen

2) Middle crust partially molten during 40-45 Ma

3) Rheology of the crust and strain distribution

4) Thermo-tectonic evolution

\section{Introduction:}

Many orogens are characterized by an abnormally high geotherm $\left(\geq 30^{\circ} \mathrm{C} / \mathrm{km}\right)$ down to the middle/lower crust (e.g., Peucat et al., 1999; Möller et al., 2000; Collins, 2002; Morisset et al., 2009; Högdahl et al., 2012; Turlin et al., 2018). A common characteristic of these "largehot" orogens (Beaumont et al., 2010) is to have cooled very slowly; estimated cooling rates are usually $\ll 10{ }^{\circ} \mathrm{C} / \mathrm{Myr}$. Thus, after temperature rose up to the metamorphic peak, it remained high over millions of years. The effects of this peculiar thermal evolution on the mechanical behavior of the lithosphere and on petrologic and geochemical systems are still not fully evaluated (e.g., Jamieson et al., 2011). Such an evolution contrasts with those of "small-cold", "alpine-type" orogens (Beaumont et al., 2010), in which temperature variations during and following orogeny are much faster. Cooling rates are in most cases high (several tens of ${ }^{\circ} \mathrm{C} / \mathrm{Myr}$ ) and, sometimes, even higher, in particular when fast exhumation follows orogen building (e.g., Zeck et al., 1992; Janots et al., 2009). Rapid temperature variations result in marked changes in the rheology of rocks over short periods of time and successive stages of the orogenic evolution are usually recorded as superimposed deformations occurring at different pressure and temperature conditions. In contrast, in a hot-orogen, temperature decreases very slowly; diachronic deformation episodes may occur under similar temperature conditions and, hence, result in similar rock microstructures and mineralogical assemblages. Consequently, it might be difficult to recognize contemporaneous deformations with contrasted kinematics from diachronous deformations separated by 10-15 Myr, for instance.

The processes that result in the formation of "hot orogens" are still poorly understood. Radiogenic heating of a highly thickened continental crust is regarded as the most efficient one (England and Thompson, 1986; Huerta et al., 1998; Vanderhaeghe et al., 2003; Clark et al., 2011; Clark et al., 2015). However, mechanical heating due to shearing or intrusion of multiple batches of mantle-derived magmas may also contribute to generate abnormally high temperatures in the middle to lower crust (Michaut and Jaupart, 2007; Nabelek et al., 2010). 
At larger scales, it was suggested that slab-retreat might trigger upwelling of asthenospheric mantle, which may contribute to heating of the overlying plate (e.g., Turlin et al., 2018 and references therein).

Three processes may combine to lower the cooling rates in a collision zone:

- High temperature in the middle crust decreases its thermal conductivity and hence its capacity to evacuate heat. A "heat reservoir" may thus form in the middle/lower crust, allowing for maintenance of an abnormal thermal gradient over long periods of time (Michaut and Jaupart, 2007; Whittington et al., 2009; Nabelek et al., 2010).

- High temperature in the middle to lower crust may trigger widespread partial melting and emplacement of large volumes of magma in the middle crust. Upon cooling, crystallization of these magmas releases latent heat of crystallization that compensates, at least partially, conductive cooling (Michaut and Jaupart, 2011).

- The viscosity of a hot and partially molten middle crust is too low to sustain high topography. When the weight due to orogenic topography exceeds the strength of the hot middle crust, it triggers a gravity-driven flow in the low-viscosity middle to lower crust, which reduces the topography and forms plateaus (e.g., Jamieson et al., 2011 and references therein). This process partly compensates orogenic thickening of the crust through frontal or/and lateral extrusion, limits erosion rates, and, consequently, hinders tectonic exhumation and associated cooling.

In Southeast Brazil, the Araçuaí belt (Figure 1) displays evidence of high temperature contractional deformation distributed almost homogeneously all over its internal domain on which focus this study, which is $\sim 200 \mathrm{~km}$ large and $>500 \mathrm{~km}$ long. Pressure-temperature estimates consistently point to synkinematic conditions between $\sim 750{ }^{\circ} \mathrm{C} / 500-600 \mathrm{MPa}$ and $\geq 800{ }^{\circ} \mathrm{C} / 600-700 \mathrm{MPa}$ (Petitgirard et al., 2009; Cavalcante et al., 2014; Moraes et al., 2015; Richter et al., 2016), supporting a temperature gradient of $30-35{ }^{\circ} \mathrm{C} / \mathrm{km}$ down to $25 \mathrm{~km}$ depth at least. Cavalcante et al. (2018) have also substantiated that anatexis was active in the core of the belt during 30 Myr. However, cooling rates were poorly constrained. Only two amphibole and three biotite ${ }^{40} \mathrm{Ar} /{ }^{39} \mathrm{Ar}$ ages from four samples, suggesting low cooling rate, have been previously published (Petitgirard et al., 2009). Here, we report 21 new ${ }^{40} \mathrm{Ar} /{ }^{39} \mathrm{Ar}$ ages in amphibole, muscovite and biotite from 16 samples representative of the different tectonic units of the Araçuaí "hot orogen". These new data, combined with previously published $\mathrm{U}-\mathrm{Pb}$ zircon ages, thermo-barometric data, and structural data from field measurements and Anisotropy of Magnetic Susceptibility (AMS) mapping (Vauchez et al., 2007; Petitgirard et al., 2009; Mondou et al., 2012; Cavalcante et al., 2013, 2014, 2018) 
103 constrain a protracted tectono-thermal evolution for this orogenic belt and confirm that

104 temperatures in the middle crust remained high over tens of Myr. Based on these results, we

105

106

107 discuss the implications of such an evolution for the strain repartition through space and time in this orogenic segment and the difficulties in applying classical tectonic analysis to hot orogens.

\section{Structure of the Araçuai belt and previous thermo-chronological data}

The Araçuaí belt (Figure 1) is a segment of a large orogenic system formed between the São Francisco, Salvador, and Congo cratons during the convergence between the South America and Africa proto-continents, which resulted in the formation of Western Gondwana (Hasui et al., 1975; Almeida, 1977; Trompette et al., 1992; Pedrosa-Soares et al., 2007). The bulk orogenic system comprises the Araçuaí-Ribeira and Cabo Frio-West Congo belts (Monié et al., 2012; Egydio-Silva et al., 2018). The convergence lasted at least one hundred millions years and diachronic orogenic climaxes have been substantiated for the Araçuaí-Ribeira orogen (600-570 Ma; e.g., Nalini et al., 2000b; Mondou et al., 2012; Gonçalves et al., 2014; Cavalcante et al., 2018) and for the West Congo belt (540-530 Ma; e.g., Monié et al. 2012). The latter event involved thrusting of the "Cabo Frio Tectonic Domain" upon the eastern Ribeira belt in the Rio de Janeiro province (Schmitt et al., 2004).

On the South American side, the Araçuaí-Ribeira belt molds the eastern to southeastern boundary of the São Francisco craton (Vauchez et al., 1994; Egydio-Silva et al., 2018; Figure 1). The Ribeira belt forms the southern segment of the orogen. It is characterized by a transpressional tectonic regime, which combined orogen-parallel transcurrent motion with orogen-normal thrusting (Vauchez et al., 1994; Egydio-Silva et al., 2002). Seismic anisotropy measurements (Heintz et al., 2003; Assumpção et al., 2006) suggest that orogen-parallel shearing involved the whole lithosphere (Vauchez et al., 2012). Northward, the connection with the Araçuaí belt is characterized by a curvature of the orogenic fabric from NE-SW to N$\mathrm{S}$ (Figure 1) and a progressive transition in strain regime to dominant westward thrusting of allochtonous units onto the São-Francisco craton in the Araçuaí belt (Vauchez et al., 1994; Oliveira et al., 2000; Egydio-Silva et al., 2005; Vauchez et al., 2007; Egydio-Silva et al., 2018). These longitudinal variations in orogenic fabric and kinematics are likely related to the termination of the São Francisco craton (Vauchez et al. 1994). Finally, the northern termination of the Araçuaí belt is characterized by dominant northward thrusting of the orogenic units onto the Salvador craton (e.g., Uhlein et al., 1998). 
The central Araçuaí belt (Figure 2), where all samples used in this study were collected 136 (location of selected samples in Supplementary Material \#1), is composed by four allochthonous domains docked against the São Francisco craton (Oliveira et al., 2000; Vauchez et al., 2007). These domains are from West to East:

- The para-autochthonous metasedimentary cover of the craton. Several U-Pb and ${ }^{207} \mathrm{~Pb} /{ }^{206} \mathrm{~Pb}$ ages in zircons $>2 \mathrm{Ga}$ obtained in this domain (e.g., Noce et al., 2000; Silva et al., 2002) support that these rocks belong to the craton. Approaching the contact with the allochthonous units, these rocks display a tectonic fabric parallel to the mylonitic fabric of the westernmost allochtonous unit, suggesting that they have been both strongly deformed under high temperature conditions during the Neoproterozoic orogeny. The foliation gently dips eastward and the lineation trends dominantly EW (Figure 2), metapelites contain acicular sillimanite, garnet, and K-feldspar and coarse-grained quartzites contain crystals of sillimanite frequently included in overgrown quartz grains. Shear criteria, although infrequent, consistently point to a top-to-west sense of shear.

- The Western Mylonitic Unit (WMU, Figure 2) is thrust westward onto the paraautochthonous cover of the craton. This unit comprises mylonites derived from metasediments, which display a foliation that gently dips eastward and bears an EW-trending lineation formed under HT-LP conditions (Petitgirard et al., 2009). The similarity of lithologies and deformation conditions with those of the para-autochthonous cratonic formations hinders a precise definition of the basal contact of the WMU. The main differences between the two units are the presence in the WMU of numerous top-to-west shear criteria (Figure 3a-d), the absence of quartzites, the alternation of metapelites with amphibolites, and the presence of large volumes (up to $40 \%$ locally) of anatectic leucogranites in decimetric veins parallel to the mylonitic foliation (Figure 3b-d). There is no evidence of strain localization at the base of the unit; strain is rather homogeneously distributed across the WMU. Indeed, the microstructure of the HT mylonites is similar across the whole unit, varying only as a function of mineralogy. Petitgirard et al. (2009) have determined metamorphic conditions for the WMU mylonites based on garnet-biotite exchange thermobarometers: core-core analyses (or biotite included in garnet) consistently yield $760-780^{\circ} \mathrm{C}\left( \pm 30^{\circ} \mathrm{C}\right)$ and rim-rim analyses, $730-760^{\circ} \mathrm{C}\left( \pm 30^{\circ} \mathrm{C}\right)$ and pressure in the range 500-600 MPa. A few ages have been published for this unit. Using the Pb-evaporation technique Noce et al. (2000) have dated two magmatic bodies (Brasilândia and Guarataia plutons) from this unit (Oliveira et al., 2000), which yielded ${ }^{207} \mathrm{~Pb} /{ }^{206} \mathrm{~Pb}$ zircon ages of $595 \pm 3$ 
and 574 \pm 2 Ma respectively, later on confirmed by Tadeschi et al. (2016). Petitgirard et al. (2009) have dated two synkinematic leucocratic granites intercalated in the mylonites: one yielded $\mathrm{U}-\mathrm{Pb}$ ages of $577 \pm 9 \mathrm{Ma}$ for zircon and $572 \pm 3 \mathrm{Ma}$ for monazite and the other yielded a zircon $\mathrm{U}-\mathrm{Pb}$ age of $578 \pm 3 \mathrm{Ma}$ (Figure 4; Table 1). These authors have reported ${ }^{40} \mathrm{Ar} /{ }^{39} \mathrm{Ar}$ ages of ca. 501 and ca. $495 \mathrm{Ma}$ for amphiboles and ca. 474 and ca. $468 \mathrm{Ma}$ for biotites from the WMU and the associated Ibituruna syenite, respectively; these preliminary data are integrated in our database (Table 1, Figure 7) and further commented (see Supplementary Material \#2 for amphibole AR-414 from the Ibituruna syenite).

- The Central Plutonic Unit (CPU; Figure 2) comprises huge volumes of synkinematic garnet-bearing granodiorites and tonalites emplaced in metasediments (e.g., Mondou et al., 2012; Narduzzi et al., 2017). These plutonic bodies (the "São Vitor" and "Galileia" batholiths) display a consistent magmatic fabric (Figure 5) that evolves eastwards from a gently eastward-dipping foliation bearing a dominantly EW-trending lineation to a steeply-dipping to subvertical foliation bearing a lineation that switches from subvertical to subhorizontal over intervals of a few tens of meters. In the easternmost part of the CPU, Mondou et al. (2012) have substantiated the presence of a corridor in which the magmatic foliation is subhorizontal and bears a strong orogen-parallel, NS-trending magmatic lineation. In several places, the granodiorites and tonalites contain elongated dioritic to gabbroic lenses (Vauchez et al., 2007; Gonçalves et al., 2014; Narduzzi et al., 2017) implying in a contribution of mantle-derived magmas to the formation of the batholiths (Figure 5c).

Metamorphic conditions in the metasedimentary country rocks of the CPU are still poorly constrained due to poor outcropping conditions, but they tend to decrease eastwards as supported by the occurrence of staurolite and, locally, of muscovite in garnet-sillimanite bearing metapelites of the easternmost part of the CPU. These minerals, indicative of temperatures $\leq 650^{\circ} \mathrm{C}$ (Nalini et al., 2015), are only present in the easternmost CPU.

Several ages have been obtained for CPU granitoids close to the contact with the WMU (Figure 4). Zircons from a tonalite sill yielded a U-Pb age of $580 \pm 8$ Ma (Petitgirard et al., 2009). Two leucocratic veins interlayered with mylonitic metasediments yielded zircon U-Pb ages of $587 \pm 5$ and $579 \pm 8 \mathrm{Ma}$ (Mondou et al., 2012). Zircons from a sample of tonalite collected $\sim 80 \mathrm{~km}$ south of the previous locations and ascribed to the CPU western boundary yielded an age of $597 \pm 4$ Ma (Gonçalves et al., 2014). 
The São Vitor tonalite was first dated at $576 \pm 5$ and $569 \pm 9$ Ma (Noce et al., 2000; ${ }^{207} \mathrm{~Pb} /{ }^{206} \mathrm{~Pb}$ ages on zircons) then, Mondou et al. (2012) obtained one U-Pb and two ${ }^{207} \mathrm{~Pb} /{ }^{206} \mathrm{~Pb}$ ages on zircons of $583 \pm 4,583 \pm 4,582 \pm 6$, and $585 \pm 4$ Ma, respectively.

The Galileia tonalitic/granodioritic batholith was dated at $594 \pm 6$ Ma (Nalini et al., $2000 \mathrm{~b} ;{ }^{206} \mathrm{~Pb} /{ }^{238} \mathrm{U}$ on zircons). Subsequently, Mondou et al. (2012) have dated samples from domains of this batholith presenting contrasted fabrics. U-Pb zircon ages from these domains with different kinematics are fairly consistent between 579 and $583 \mathrm{Ma}$.

The muscovite-bearing Palmital peraluminous granite was dated at $582 \pm 2 \mathrm{Ma}$ (Nalini et al., 2000a) and the cordierite-garnet-biotite-bearing Wolf leucogranite at $582 \pm 5 \mathrm{Ma}$ (Noce et al., 2000) and $585 \pm 4 \mathrm{Ma}(\mathrm{U}-\mathrm{Pb}$ on zircons; Mondou et al., 2012). These two granites (Figures 2,4) likely result from melting of aluminous metapelites contemporaneous to the melting of the lower crust and underlying mantle that formed the tonalitic/granodioritic magmas.

- Intermediate, discontinuous kinzigitic unit (Figures 2 and 6). The steeply dipping, medium temperature, staurolite-bearing metasediments that crop out in the easternmost part of the CPU are separated from the gently dipping Eastern Anatectic Unit (EAU; see below) by a discontinuous unit of partially molten kinzigites with a steeply-dipping foliation (Oliveira et al., 2000; Mondou et al., 2012). In contrast with metasediments of the easternmost CPU, these kinzigites contain biotite, garnet, cordierite, sillimanite, but no staurolite or muscovite. The tectonic contact between these kinzigites and the CPU is therefore characterized by a metamorphic gap, despite the similar subvertical fabric recorded by the two units. This suggests that the intermediate kinzigitic unit, initially equilibrated at deeper levels, has been thrust upon the CPU and that, subsequently, the tectonic contact and associated fabric have been verticalized.

- The Eastern Anatectic Unit (EAU, also known as "Carlos Chagas leucogranite"; Figures 2 and 6) is more than $300 \mathrm{~km}$ long and 50 to $100 \mathrm{~km}$ wide. It comprises peraluminous metatexites, diatexites, and leucogranites containing quartz, K-feldspar, garnet, biotite, sillimanite, \pm rutile, \pm cordierite (e.g., Cavalcante et al., 2013). Some garnet-bearing leucogranites are almost free of biotite (Figure 6c). Rather than a batholith, the EAU represents the anatectic core of the Araçuaí belt, which was intruded by several late orogenic charnockitic plutons ( $520 \mathrm{Ma})$. This unit is characterized by a widespread, penetrative magmatic fabric marked by a magmatic foliation that dominantly dips gently to moderately in 
various directions due to open folds that affected an initial low-angle foliation (Cavalcante et 232 al., 2013). Detailed mapping of magnetic foliations and lineations across the EAU revealed a complex flow field, characterized by a western domain where gently dipping foliations bear 234 lineations that progressively rotate from SW in the south to NW in the north (Figure 2) and by an eastern domain where subvertical NS-trending foliations bear sub-horizontal, orogenparallel lineations (Cavalcante et al., 2013). The eastern boundary of the anatectic unit is defined by a progressive transition to migmatitic kinzigites (Figure 6d) in which are intercalated layers of orthopyroxene-bearing granulites.

Cavalcante et al. $(2014,2018)$ using the Ti-in-quartz (TitaniQ), the Zr-in-rutile geothermometers in anatexites and Fe-Mg exchange geothermobarometers in neighbouring kinzigites obtained temperatures of $780-800{ }^{\circ} \mathrm{C}$ and pressures in the range of $650-700 \mathrm{MPa}$; these P-T conditions are interpreted as those under which crystallization of anatexites began during cooling. These thermobarometric estimates are in good agreement with those obtained for the migmatitic kinzigites by Munhá et al. (2005) using $\mathrm{Fe}-\mathrm{Mg}$ exchange geothermobarometers and, more recently, by Richter et al. (2016) from phase equilibrium modeling. Such P-T conditions are consistent with the presence of cordierite (Harley et al., 2002; Pattison et al., 2003; Harley, 2004) in the studied rocks and also of rutile that, according to Le Breton and Thompson (1988), crystallizes at $\mathrm{T} \geq 760{ }^{\circ} \mathrm{C}$. Evidence of destabilization of restitic biotites in several samples further supports temperatures $>800{ }^{\circ} \mathrm{C}$ (Le Breton and Thompson, 1988; Vielzeuf and Holloway, 1988; Pattison et al., 2003). As highlighted by Cavalcante et al. (2014), such high temperatures probably allowed for melt fractions $>30 \%$, which may have drastically reduced the viscosity of the anatectic middle crust (Rosenberg and Handy, 2005; Vanderhaeghe, 2009). Moreover, the contrast in peak equilibrium temperatures supports a major tectonic contact between the central (CPU) and eastern (EAU) units.

Vauchez et al. (2007) reported a SHRIMP U-Pb zircon age of $575 \pm 3$ Ma for a diatexite from the EAU. Additional U-Pb SHRIMP zircon ages from anatectic granite, diatexites, and metatexites substantiate a broad variability in U-Pb zircon ages across the EAU (Cavalcante et al., 2018). Several diatexites and anatectic granites yielded ages in the range 597-593 Ma, whereas the remaining anatectic samples were dated between 589 and 572 Ma. Ages are on average slightly older in the northwest and younger in the southeast, but the trend is not clearcut (Figure 5). Richter et al. (2016) reported a similar age range (595-570 Ma) for samples from the easternmost "Nova Venecia" kinzigitic unit of the Araçuaí belt. These data indicate 
that anatexis was already underway in the middle crust $(\sim 25 \mathrm{~km})$ of the Araçuaí belt by $\sim 600 \mathrm{Ma}$ and that it remained active until at least $570 \mathrm{Ma}$ (Cavalcante et al., 2018).

\section{3. ${ }^{40} \mathrm{Ar} /{ }^{39} \mathrm{Ar}$ ages}

Ten samples were collected across the CPU: two synkinematic tonalites from the contact between this domain and the WMU, five synkinematic granodiorites/tonalites from the São Vitor and Galiléia complexes showing a well developed magmatic fabric, one synkinematic leucogranite (Wolf granite), one muscovite-bearing peraluminous granite from the Palmital plutonic body, and one orthogneiss from the country rock (Figure 7). The U-Pb zircon ages of six of the selected plutonic rocks are close to $580 \mathrm{Ma}$ (Mondou et al., 2012). Biotite was separated and analyzed for the 10 samples; amphibole was analyzed in four tonalites, and muscovite in the peraluminous Palmital granite (see Table 1).

Six samples from the EAU were selected among the 12 recently dated by Cavalcante et al. (2018): four anatectic granites, one diatexite and one metatexite (Figure 4, Table 1). Their $\mathrm{U}-\mathrm{Pb}$ zircon ages range between 597 and $572 \mathrm{Ma}$. All selected samples display a welldeveloped magmatic foliation and are free of solid-state deformation (Cavalcante et al., 2013). Only biotite was dated since amphibole was not found in anatexites.

The location of the samples for which ${ }^{40} \mathrm{Ar} /{ }^{39} \mathrm{Ar}$ ages were obtained in this study is shown on Figure 7, which also integrates ${ }^{40} \mathrm{Ar} /{ }^{39} \mathrm{Ar}$ ages obtained previously (Table 1, 2 amphibole and 3 biotite ages from Petitgirard et al., 2009). Samples from the CPU were analyzed at Geosciences Montpellier (University of Montpellier, France) and those from the EAU at the Geochronological Research Center of the University of São Paulo (Brazil). ${ }^{40} \mathrm{Ar} /{ }^{39} \mathrm{Ar}$ diagrams are shown on Figures 9 and 10 . Full analytical data are available in the Supplementary Material \#3 and \#4.

In the $\mathrm{CPU},{ }^{40} \mathrm{Ar} /{ }^{39} \mathrm{Ar}$ cooling ages on amphibole, muscovite, and biotite show a larger dispersion than the $\mathrm{U}-\mathrm{Pb}$ ages on zircon; they range from about 550 to $470 \mathrm{Ma}$ (Figure 7). This dispersion reflects both the difference of closure temperatures between amphibole and micas and the variability from sample to sample. Amphiboles from tonalite/granodiorite samples provide nearly undisturbed age spectra with plateau ages ranging from $549.2 \pm 5.6$ Ma to $500 \pm 5 \mathrm{Ma}$ (Figure 8). Biotites from the São Vitor and Galileia tonalites/granodiorites yielded ${ }^{40} \mathrm{Ar} /{ }^{39} \mathrm{Ar}$ ages between $489.5 \pm 5.4 \mathrm{Ma}$ and $474.5 \pm 4.4 \mathrm{Ma}$; those of the Wolf leucogranite $491.9 \pm 5.8 \mathrm{Ma}$ and those from the Palmital granite and one orthogneiss sample overlap at $484.1 \pm 4.7 \mathrm{Ma}$. Muscovite from the Palmital granite yield plateau age of $487.6 \pm$ 4.5 Ma for more than $90 \%$ of the released ${ }^{39} \mathrm{Ar}$ (Figure 8). Two samples of tonalite collected 
close to the contact between the WMU and the CPU yield older cooling ages for amphibole $(549.2 \pm 5.6$ and $541.6 \pm 7.7 \mathrm{Ma})$ and biotite $(532.2 \pm 5.4$ and $507.5 \pm 5.3 \mathrm{Ma})$. Although these ages are reliable from the analytical point of view, their geological significance remains unclear since for neighboring samples collected on both sides of this contact amphibole and biotite yield younger cooling ages in the range 510-470 Ma.

In the EAU, biotite ages span from $485.8 \pm 4.4 \mathrm{Ma}$ to $458.5 \pm 4.2 \mathrm{Ma}$ with the oldest age obtained for the northernmost sample and the youngest one for the southernmost sample (Figure 9; Supplementary Material \#4). This distribution is correlated with the variation in U$\mathrm{Pb}$ zircon ages across this domain.

\section{Discussion}

\subsection{Origin and duration of the heating episode}

Considering the current crustal thickness of $440 \mathrm{~km}$ (Assumpção et al., 2013) and the paleopressures of 0.6-0.7 GPa recorded by rocks currently exposed in the central Araçuaí orogen (Petitgirard et al., 2009; Cavalcante et al., 2014; Richter et al., 2016), the orogenic crustal thickness was likely $>60 \mathrm{~km}$. Temperatures of 740 to $\geq 800{ }^{\circ} \mathrm{C}$ were recorded at $20-25$ km depth (Petitgirard et al., 2009; Cavalcante et al., 2014; Richter et al., 2016) suggesting an average thermal gradient $>30^{\circ} \mathrm{C} / \mathrm{km}$ within the upper and middle crust (likely lower in the lower crust). Throughout the orogen, the magmatic bodies are either embedded in metapelitic rocks or formed by local anatexis of metapelitic rocks. This supports that the orogenic middle crust of the Araçuaí belt, down to $25 \mathrm{~km}$ depth at least, was mostly composed by metapelites with some amphibolite and quartzite intercalated layers. Although the content in heatproducing elements of these metapelites is not known, such a middle crust likely had a rather high radiogenic heat production, which probably contributed significantly to heating (Clark et al., 2011; Clark et al., 2015). In response to heating, it underwent prograde metamorphic reactions that produced free water favoring extensive partial melting (Weinberg and Hasalová, 2015).

The presence of diorite/gabbros mingled within the granodioritic/tonalitic bodies of the CPU (Figure 5c) indicates that partial melting also affected the underlying mantle (Mondou et al., 2012; Gonçalves et al., 2014). Heating in the lithospheric mantle may be due to enrichment in heat-producing elements resulting from metasomatic reactions (Neves et al., 2008) during pre-orogenic rifting of the lithosphere along the eastern border of the São Francisco craton (Cunningham et al., 1996; Uhlein et al., 2007). 
Available $\mathrm{U}-\mathrm{Pb}$ ages on zircons are remarkably consistent across the various geological units that shape the central part of the Araçuaí orogen. Similar ages have been reported in the northern (Siga Jr et al., 1987) and southern portions of the belt, including its connection with the Ribeira transpressional belt (Silva et al., 2005; Bento dos Santos et al., 2010). Ages obtained in the EAU (Cavalcante et al., 2018) and in the kinzigites that bound it eastwards (Richter et al., 2016; Melo et al., 2017) support that by 600 Ma the middle/lower crust (0.6$0.7 \mathrm{GPa}$ ) of the Araçuaí orogen had reached temperatures $\sim 800{ }^{\circ} \mathrm{C}$ and was already partially molten, producing garnet-rich aluminous magmas. Following this metamorphic peak, huge volumes of synkinematic granodioritic/tonalitic magmas were emplaced in the CPU. They systematically display a magmatic fabric that, although variable through the whole CPU, is always consistent with the fabric of the country rock, and their ages are in the range 585-575 Ma independently of the orientation of their magmatic fabric (Mondou et al., 2012). In this plutonic complex, only a few ages older than 600 Ma have been obtained (Silva et al., 2005).

The data support that contractional tectonics and crustal thickening started significantly earlier than $600 \mathrm{Ma}$. A rough estimate may be obtained based on data from the EAU considering heating rates in the range of $5-20{ }^{\circ} \mathrm{C} / \mathrm{Myr}$ (Harris et al., 2000 and references therein) or $8-15{ }^{\circ} \mathrm{C} / \mathrm{Myr}$, as recently deduced from allanite and monazite dating in the central Alps by Janots et al. (2009). Assuming an initial temperature of $\sim 400{ }^{\circ} \mathrm{C}$ at $20-25 \mathrm{~km}$ depth (McKenzie et al., 2005), heating up to $800{ }^{\circ} \mathrm{C}$ would have required between 27 and $50 \mathrm{Myr}$. This would imply that deformation producing thickening and prograde metamorphism in the Araçuaí belt started before $630 \mathrm{Myr}$ ago. Such a delay between the initiation of the orogeny and the occurrence of widespread partial melting is in agreement with estimates from models for the southern India developed by Clark et al. (2015). It is also consistent with the time intervals (20-60 Myr) between the initiation of collision and melting of the middle/lower crust under peak metamorphism conditions, estimated for the southern Tibet and the High

354 Himalayas or the Canadian Cordillera (e.g., Vanderhaeghe and Teyssier, 2001b and references therein; Zhang et al., 2004; Guo and Wilson, 2012).

The granodioritic/tonalitic bodies of the CPU yield consistent ages in the range 590-570 Ma. These plutonic units display a magmatic fabric parallel to the solid-state fabric of their country rocks, of the mylonites in the WMU, and of the intermediate kinzigitic unit between the CPU and EAU. This supports synkinematic emplacement of huge volumes of granodioritic and tonalitic magmas in the middle crust (Vauchez et al., 2007; Mondou et al., 2012) during the temperature climax, the magmas likely resulting from partial melting of the 
lower crust, with minor contribution from mantle melting, as evidenced from mixing with dioritic and gabbroic magmas (Gonçalves et al., 2014).

Younger ages obtained on several late- and post-collisional granitic bodies (Silva et al., 2002, 2005; Mondou et al., 2012) highlight that magmatic pulses occurred over a very long period of time until, at least, $500 \mathrm{Ma}$. Among the late magmatic bodies, the "Ibituruna" Syenite in the CPU (U-Pb zircon age of $530 \mathrm{Ma}$; Petitgirard et al., 2009) and the "Padre Paraíso" charnockitic suite in the EAU (U-Pb zircon ages of 520 Ma; Noce et al., 2000; Mondou et al., 2012) still have a poorly understood origin. Their compositions imply nevertheless that rather high temperature conditions subsisted in the lower crust and underlying mantle up to these late stages of the evolution of the Araçuaí belt. It is worth noticing that the Ibituruna syenite ( $\sim 530 \mathrm{Ma})$ has a magmatic fabric (foliation and lineation) parallel to the solid-state fabric in the surrounding HT mylonites (Petitgirard et al., 2009), whereas the charnockites crosscut the tectonic fabric of the Araçuaí belt (e.g., Oliveira et al., 2000; Mondou et al., 2012). Interestingly, these late magmatic events in the Araçuaí belt are coeval with the main tectono-metamorphic event in the West Congo belt in Angola (Monié et al., 2012) and in the "Cabo Frio Tectonic Domain" (Schmitt et al., 2004). They might, therefore, record limited reactivation of the Araçuaí belt in response to the formation of the "Congo-Cabo Frio" belt during the final collision between the African and South American proto-continents at 540-530 Ma.

\subsection{Cooling rates}

In this section, we will only consider $\mathrm{U}-\mathrm{Pb}$ and ${ }^{40} \mathrm{Ar} /{ }^{39} \mathrm{Ar}$ ages obtained by our group (Table 1; Vauchez et al., 2007: Petitgirard et al, 2009; Mondou et al., 2012; Cavalcante et al., 2018; this work), for which the location of samples, the definition of the rock type and, in case of magmatic rocks, the synkinematic or post-kinematic emplacement and absence of solid-state reworking are well known. This choice does not alter the results, since there is a good agreement between the ages obtained in different studies for rocks from the Araçuaí belt.

Since our goal was to estimate the cooling temperature at the regional scale, to define the minimum starting temperature of the cooling path we have used the equilibrium temperatures estimated for the metamorphic country rocks $\left(\sim 750{ }^{\circ} \mathrm{C}\right.$; Petitgirard et al., 2009) and the U-Pb zircon ages of synkinematic magmas in the WMU (577-578 Ma; Petitgirard et al., 2009). For the anatexites of the EAU, we have considered U-Pb zircon ages obtained across the domain (597-570 Ma; Cavalcante et al., 2018) and the maximum temperatures 
Zr-in-Rutile thermometers (790 ${ }^{\circ} \mathrm{C}$, Cavalcante et al., 2018). These temperatures are not necessarily representative of the metamorphic peak conditions, since the magmas were already crystallizing and thus cooling, but they rather provide a robust value for the starting temperatures of the cooling path. Finally, for the youngest anatexites of the EAU (570-578 $\mathrm{Ma})$, we have considered that their Ti-in-Zircon temperatures $\left(720-740{ }^{\circ} \mathrm{C}\right.$; Cavalcante et al., 2018) represent the minimum value of the equilibrium temperature at this time.

Figure 10 summarizes all ages obtained by our group for the Araçuaí belt. Zircon U-Pb ages from synkinematic leucogranites in mylonites from the WMU, granodiorites/tonalites from the $\mathrm{CPU}$, and anatexites from the EAU spread from $\sim 600 \mathrm{Ma}$ to $\sim 570 \mathrm{Ma}$ with a clear concentration around $580 \mathrm{Ma}(19 / 29$ ages between 575-585 Ma, 8/29 between 585 and $600 \mathrm{Ma})$, supporting that the metamorphic peak, partial melting, and tonalitic/granodioritic magmatism occurred during this period of time. To estimate a mean cooling rate, we use the median value of $584 \mathrm{Ma}(\sigma=7)$ calculated based on 27 zircon ages (excluding the late Ibituruna syenite AR-414 and the orthogneiss AR-722). Temperature and pressure estimates support that, by $\sim 600-580 \mathrm{Ma}$, metamorphic temperature at 20-25 km depth was in the range of $750{ }^{\circ} \mathrm{C}$ (WPU, Petitgirard et al., 2009) to $\geq 800{ }^{\circ} \mathrm{C}$ (EAU; Cavalcante et al., 2014). These values crudely define the minimum starting temperature of the cooling path (Figure 10).

Almost all dated minerals are of magmatic origin, except the recrystallized biotite extracted from orthogneiss AR-722, which has an U-Pb zircon age of $2103 \pm 11 \mathrm{Ma}$ (Mondou et al., 2012), but yielded similar ${ }^{40} \mathrm{Ar} /{ }^{39} \mathrm{Ar}$ age as the magmatic biotites. ${ }^{40} \mathrm{Ar} /{ }^{39} \mathrm{Ar}$ ages on amphibole and micas record, therefore, cooling through the respective closure temperatures. A first estimate of the cooling rate was obtained considering closure temperatures of $550 \pm$ $30{ }^{\circ} \mathrm{C}$ for amphibole (Dahl, 1996), $400 \pm 20^{\circ} \mathrm{C}$ for muscovite (Harrison et al., 2009), and 325 $\pm 20^{\circ} \mathrm{C}$ for biotite (Harrison et al., 1985). However, for very low cooling rates, the isotopic re-equilibration may continue at temperatures lower than the theoretical closure temperature (Dodson, 1973). We have thus recalculated the closure temperatures for amphibole, muscovite and biotite taking into account the estimated cooling rate $\left(5^{\circ} \mathrm{C} / \mathrm{Myr}\right.$ for amphibole and $15{ }^{\circ} \mathrm{C} / \mathrm{Myr}$ for biotite and muscovite) and the grain size (Brandon et al., 1998; McDougall and Harrison, 1999; Braun et al., 2006; Reiners and Brandon, 2006). Depending on grain size, estimated closure temperatures range from 485 to $526{ }^{\circ} \mathrm{C}$ for amphibole, 288 to $338{ }^{\circ} \mathrm{C}$ for biotite and $416 \pm 4{ }^{\circ} \mathrm{C}$ for the single analyzed muscovite (Table 1 ).

Cooling rates inferred for various scenarios are shown on Figure 10:

- The first one (curve 1) is calculated using: 1) average ages computed considering all samples (except the syenite AR-414 and the orthogneiss AR-722 as stated 
above), i.e., $584 \mathrm{Ma}$ for U-Pb zircon age, $510 \mathrm{Ma}$ and $487 \mathrm{Ma}$ for ${ }^{40} \mathrm{Ar} /{ }^{39} \mathrm{Ar}$ amphibole and biotite ages respectively, 2) the average closure temperatures of amphibole $\left(508{ }^{\circ} \mathrm{C}\right)$ and biotite $\left(316{ }^{\circ} \mathrm{C}\right)$. This results in cooling rates of $3.9{ }^{\circ} \mathrm{C} / \mathrm{Myr}$ with an initial temperature $\left(\mathrm{T}_{\mathrm{i}}\right)$ of $800{ }^{\circ} \mathrm{C}$ (curve 1) between 584 and $510 \mathrm{Ma}\left(3.3{ }^{\circ} \mathrm{C} / \mathrm{Myr}\right.$ with $\left.\mathrm{T}_{\mathrm{i}}=750{ }^{\circ} \mathrm{C}\right)$ and of $8.4^{\circ} \mathrm{C} / \mathrm{Myr}$ between 510 and $487 \mathrm{Ma}$.

- For the second scenario (curve 2), we excluded the two samples that yielded significantly older amphibole and biotite ${ }^{40} \mathrm{Ar} /{ }^{39} \mathrm{Ar}$ ages, and used average closure temperatures of $504{ }^{\circ} \mathrm{C}$ for amphibole and of $319^{\circ} \mathrm{C}$ for biotite. The obtained cooling rates are of $3.5{ }^{\circ} \mathrm{C} / \mathrm{Myr}$ between 584 and $499 \mathrm{Ma}$ with $\mathrm{T}_{\mathrm{i}}=800{ }^{\circ} \mathrm{C}$ $\left(2.9^{\circ} \mathrm{C} / \mathrm{Myr}\right.$ with $\left.\mathrm{T}_{\mathrm{i}}=750{ }^{\circ} \mathrm{C}\right)$ and of $9.7^{\circ} \mathrm{C} / \mathrm{Myr}$ between 499 and $480 \mathrm{Ma}$.

- Even considering only the oldest ages obtained for amphibole (average: $546 \mathrm{Ma}$ ) and biotite (average: $520 \mathrm{Ma}$ ), cooling rates still remain low (curve 3): $7.6{ }^{\circ} \mathrm{C} / \mathrm{Myr}$ between 583 and $546 \mathrm{Ma}$ with $\mathrm{T}_{\mathrm{i}}=800{ }^{\circ} \mathrm{C}\left(6.3{ }^{\circ} \mathrm{C} / \mathrm{Myr}\right.$ with $\left.\mathrm{T}_{\mathrm{i}}=750{ }^{\circ} \mathrm{C}\right)$. Cooling rates below the closure temperature of amphibole range between $16.1^{\circ} \mathrm{C} / \mathrm{Myr}$ (with AR-590 biotite age of $532 \mathrm{Ma}$ ) and $5.8^{\circ} \mathrm{C} / \mathrm{Myr}$ (with AR-1057 biotite age of 508 $\mathrm{Ma}$ ) and $8.7^{\circ} \mathrm{C} / \mathrm{Myr}$ for the average age of biotites (520 Ma).

Local cooling rates for the EAU can be estimated using biotite ${ }^{40} \mathrm{Ar} /{ }^{39} \mathrm{Ar}$ ages of the six samples for which Cavalcante et al. (2018) obtained U-Pb zircon ages between 597 and 572 Ma (Table 1; Figures 5, 9). Biotite from these samples yield ${ }^{40} \mathrm{Ar} /{ }^{39} \mathrm{Ar}$ ages from 486 to 459 $\mathrm{Ma}$ and closure temperatures from 307 to $338{ }^{\circ} \mathrm{C}$. Considering the oldest anatectic leucogranites of the EAU (AR-1133; curve 4 on Figure 10), which has U-Pb zircon age of $597 \pm 3 \mathrm{Ma}$ and ${ }^{40} \mathrm{Ar} /{ }^{39} \mathrm{Ar}$ biotite age of $486 \pm 4$, the TitaniQ temperature for this unit of $\sim 800{ }^{\circ} \mathrm{C}$ (Cavalcante et al., 2014) as initial temperature, and $307{ }^{\circ} \mathrm{C}$ as the closure temperature of biotite, we obtain an average cooling rate of $\sim 4.4^{\circ} \mathrm{C} / \mathrm{Myr}$ during the $\geq 110 \mathrm{Myr}$ that followed the crystallization of zircons. Sample AR-1349, for which an equilibrium temperature of $780-790{ }^{\circ} \mathrm{C}$ was estimated using Zr-in-rutile data (Cavalcante et al., 2018), yields $\mathrm{U}-\mathrm{Pb}$ zircon age of $583 \mathrm{Ma}$ and ${ }^{40} \mathrm{Ar} /{ }^{39} \mathrm{Ar}$ biotite age of $476 \mathrm{Ma}$ (closure $\mathrm{T}: 323{ }^{\circ} \mathrm{C}$ ), pointing to an average cooling rate of $\sim 4.3{ }^{\circ} \mathrm{C} / \mathrm{Myr}$. For the youngest anatectic sample (AR1370), the ${ }^{40} \mathrm{Ar} /{ }^{39} \mathrm{Ar}$ biotite age is $469 \mathrm{Ma}$ with a closure temperature of $\sim 316^{\circ} \mathrm{C}$, the $\mathrm{U}-\mathrm{Pb}$ zircon age is $572 \mathrm{Ma}$, and a minimum ambient temperature of $\sim 720{ }^{\circ} \mathrm{C}$ may be assumed from Ti-in-zircon data (Cavalcante et al., 2018). This points to cooling by $\sim 404{ }^{\circ} \mathrm{C}$ in $103 \mathrm{Myr}$ and, 460 therefore, to an average cooling rate of $3.9^{\circ} \mathrm{C} / \mathrm{Myr}$. These cooling rates estimated for the 461 EAU rely on ${ }^{40} \mathrm{Ar} /{ }^{39} \mathrm{Ar}$ biotite ages and closure temperatures only. They lack intermediate 
constraints and therefore consider a linear cooling between the crystallization of zircons and the closure of the K/Ar system in biotite. Taking into account the difference in cooling rates above and below the closure temperature of amphibole obtained for rocks from the WMU and the CPU, a cooling rate significantly lower than $4{ }^{\circ} \mathrm{C} / \mathrm{Myr}$ may also be expected for the EAU during the first tens of million years after the peak of metamorphism.

In summary, $\mathrm{U}-\mathrm{Pb},{ }^{40} \mathrm{Ar} /{ }^{39} \mathrm{Ar}$ ages and the metamorphic temperature estimates from the three allochthonous units consistently suggest low cooling rates $\left(\sim 3\right.$ to $8{ }^{\circ} \mathrm{C} / \mathrm{Myr}$; likely 3 $5{ }^{\circ} \mathrm{C} / \mathrm{Myr}$ ) during at least the first $40 \mathrm{Myr}$ after initiation of cooling (based on the oldest ${ }^{40} \mathrm{Ar} /{ }^{39} \mathrm{Ar}$ ages of amphiboles, Am3 on Figure 10), more probably 70-80 Myr (based on the average amphibole ${ }^{40} \mathrm{Ar} /{ }^{39} \mathrm{Ar}$ age, Am1 on Figure 10), or even $>100 \mathrm{Myr}$ in the EAU. These data also imply that cooling was faster (at least $11-15^{\circ} \mathrm{C} / \mathrm{Myr}$ ) after the closure of the amphibole K/Ar system, and possibly even faster ( $>20^{\circ} \mathrm{C} / \mathrm{Myr}$ ) approaching the closure temperature of muscovite, although this last inference needs further investigation since it relies on the single muscovite age of our database. Moreover, as discussed above, the estimated cooling rates consider linear trends between the different time markers (crystallization of zircon and the closure of ${ }^{40} \mathrm{Ar} /{ }^{39} \mathrm{Ar}$ system in amphibole and biotite). Yet, cooling was probably lower right after the metamorphic peak, especially during progressive solidification of magmatic rocks, due to the release of the latent heat of crystallization (Michaut and Jaupart, 2011), and has progressively increased through time. However, although no evidence has been found yet, episodes of reheating cannot be ruled out.

The present estimates of cooling rates in the Araçuaí belt are in rather good agreement with those proposed by Bento dos Santos et al. $(2010 ; 2014)$ for anatexites, granulites, and charnockites from the northern Ribeira belt. These authors propose a two-step thermal evolution with initial cooling rates of $1-5{ }^{\circ} \mathrm{C} / \mathrm{Myr}$ during 50-90 Myr, followed by faster cooling by $8-30{ }^{\circ} \mathrm{C} / \mathrm{Myr}$ and possibly up to $100{ }^{\circ} \mathrm{C} / \mathrm{Myr}$, based on diffusion of $\mathrm{Fe}^{2+}$ and $\mathrm{Mg}$ between garnet and biotite inclusions. Although the approaches are different, estimates obtained in both areas consistently point to a very slow cooling during several tens of million years after the major high temperature deformation that shaped the Araçuaí and the northern Ribeira belts.

${ }^{40} \mathrm{Ar} /{ }^{39} \mathrm{Ar}$ ages of $498-493 \mathrm{Ma}$ for amphibole and of 487 to $466 \mathrm{Ma}$ for biotite obtained in the West Congo belt in Angola (Monié et al., 2012) are similar to those obtained in the Araçuaí belt, suggesting that, although the age of the orogenic/metamorphic peak is different in these two belts (Araçuaí : 600-580 Ma; West Congo 540-530 Ma), they shared a common cooling history after the final amalgamation of Western Gondwana. 

rheology and strain repartition

Under "hot orogen" conditions (high temperatures and low cooling rates in the middle and lower crust), we may expect specific rheological behaviors. When the temperature gradient reaches equilibrium, it is almost homogeneous over large distances both laterally and vertically (e.g., Whittington et al., 2009). Rheological contrasts between different crustal rock types are minimized, and strain localization efficiency, which is inversely proportional to stress and thus to temperature, becomes much lower. Strain tends to be distributed over large volume of rocks (Vanderhaeghe and Teyssier, 2001b; Vauchez et al., 2007). Consequently, transitions between orogenic domains should be much smoother than under lower temperature conditions (Vanderhaeghe and Teyssier, 2001a). This is particularly true when the middle to lower crust undergoes widespread partial melting, because this process may lead to a decrease in viscosity by several orders of magnitude (e.g., Rosenberg and Handy, 2005; Rosenberg et al., 2007; Cavalcante et al., 2014). The presence of even a small proportion of melt in a rock significantly modifies its viscosity. For instance, Rosenberg and Handy (2005) pointed out through reinterpretation of experimental data on partially molten systems that the strength of a rock undergoes a drastic drop during the first $\sim 7 \%$ of partial melting. They also argued that, symmetrically, the strength of magmas deforming during crystallization remains low until they reach a proportion of solid-phase of $\sim 90 \%$ and then increases rapidly up to the solidus. When cooling is slow, as it is the case in the Araçuaí orogen, high melt fractions subsist for long times and, by consequence, partially crystallized magmatic bodies or partially molten anatexites may accommodate most of the strain, either gravity-induced or due to far-field forces, during most of the duration of the continental collision.

The three main allochthonous units of the Araçuaí orogen are characterized by the presence of large volumes of synkinematic magmas intermingled with metasedimentary rocks: leucogranites interlayered with mylonites in the western unit, granodiorites/tonalites in the central unit, and anatexites in the eastern unit. Such large volumes of magmas in the middle crust certainly had a major impact on the rheology of the orogenic lithosphere. Using the cooling rates discussed in the previous section, we may roughly estimate the time lapse between emplacement and solidification of the magmas. For instance, the oldest anatectic granite of the EAU, emplaced at $\sim 597 \mathrm{Ma}$ in the middle crust at a minimum temperature of $800{ }^{\circ} \mathrm{C}$ yields a mean cooling rate of $\sim 4{ }^{\circ} \mathrm{C} / \mathrm{Myr}$, suggesting that the solidus temperature $\left(\sim 630{ }^{\circ} \mathrm{C}\right)$ was attained at least $40-45 \mathrm{Myr}$ after its emplacement, i.e., at about 550-555 Ma. 
530 leucogranites of the WMU and the tonalite and granodiorites of the CPU emplaced at $\sim 580$

531 Ma in mylonites or metasediments equilibrated at $\sim 750{ }^{\circ} \mathrm{C}$, which yield cooling rates of 3-

$5324{ }^{\circ} \mathrm{C}$. The consistent estimates for the different units of the Araçuaí belt support that the large 533 volumes of magmas emplaced or formed in the three allochthonous units allowed for 534 magmatic flow and hence maintained low strengths in the middle crust for 40 Myr after 535 initiation of cooling. Considering the suggestion by Ackerson et al. (2018) that granitic and 536 granodioritic magmas may contain a significant volume of interstitial magma down to 537 temperatures as low as $\sim 500{ }^{\circ} \mathrm{C}$, the above value may be still an underestimate. Indeed, in the 538 Grenville Province in North America, cooling rates in the range 2.3-4.4 ${ }^{\circ} \mathrm{C} / \mathrm{Myr}$ and maintenance of supra-solidus conditions over $\geq 70$ Myr have been substantiated (Turlin et al., 2018). The presence today, as deduced from seismic profiles (Nelson et al., 1996), of a partially molten middle crust beneath Tibet, which results from partial melting initiated 20-25 542 Myr ago (Zhang et al., 2004; Guo and Wilson, 2012), illustrates that a long-lived partially 543 molten crust may have been present in orogens of a variety of ages.

Viscosity increase upon cooling may generate a strength inversion between the magmatic bodies and their country rocks. Nabelek and Liu (2004) suggested, for instance, inversion of shear strength between a mica schist and a dry granite at a temperature of ca. $530{ }^{\circ} \mathrm{C}$ depending weakly on strain rate. Based on the cooling rates estimated from our data, strength inversion between metapelitic country rocks and magmatic bodies might have occurred as late as $60 \mathrm{Myr}$ after emplacement of the magmatic bodies. The magmatic bodies were therefore the most deformable part of the middle crust during several tens of million years and, considering their large volume, likely accommodated most of the strain imposed by both plate tectonics and gravity. Upon cooling and crystallization of the magmas, the strength 553 of the magmatic rocks became higher than the strength of the metasedimentary country rocks and the late pulses of deformation must have been accommodated mostly in metasediments.

The viscosity increase during cooling in a hot orogen may also lead to a progressive 556 decrease of the contribution of gravity-driven forces to regional deformation so that the strain 557 regime becomes dependent on far-field forces only. Strengthening of the middle crust may 558 also have allowed more effective transmission of tectonic forces toward the external domains 559 of the orogen, which are, in the present case, the remobilized eastern border of the São 560 Francisco craton. 


\subsection{Tectonic evolution of the Araçuaí belt}

The slow cooling rates estimated in this study and their possible rheological consequences require reconsidering the tectonic evolution of the Araçuaí belt. As stated above, a characteristic of this orogenic segment is that strain was almost evenly distributed across the tectonic units described previously and occurred under high temperature conditions in the presence of syntectonic magmas. However, detailed mapping revealed that the tectonic fabric is variable across the belt. In the CPU and EAU in particular, the foliation and lineation form a complex pattern supporting a 3D deformation (Mondou et al., 2012; Cavalcante et al., 2013). Even if domains with different tectonic fabrics display consistent HT conditions of deformation and similar $\mathrm{U}-\mathrm{Pb}$ ages of synkinematic magmas, the question of their contemporaneity remains open, since the present study substantiates that HT conditions were maintained during several tens of Myr. In partially molten rocks a new deformation event tends to erase evidence of any previous one. Fast diffusion, allowing for easy grain boundary migration, may have the same effect in HT metamorphic rocks. Under such conditions, it is difficult to establish a reliable chronology since classical techniques of structural analysis are therefore less efficient than in faster cooling orogenic belts.

Interestingly, despite the homogeneity of rock types, equilibrium temperatures, and systematic deformation in the magmatic state throughout the whole EAU, geochronological data denote a diachronous tectonothermal evolution within this unit. There is a correlation between the southeastward decrease in zircon ages evidenced by Cavalcante et al. (2018) and the variation in ${ }^{40} \mathrm{Ar} /{ }^{39} \mathrm{Ar}$ biotite ages across the EAU. Samples with the oldest $\mathrm{U}-\mathrm{Pb}$ ages were the first ones to reach the closure temperature of biotite and samples with the youngest $\mathrm{U}-\mathrm{Pb}$ ages also yield the youngest ${ }^{40} \mathrm{Ar} /{ }^{39} \mathrm{Ar}$ biotite ages (Figure 11). Only the ${ }^{40} \mathrm{Ar} /{ }^{39} \mathrm{Ar}$ age of biotite from the anatectic granite AR-535 does not follow this tendency, displaying a younger than expected biotite ${ }^{40} \mathrm{Ar} /{ }^{39} \mathrm{Ar}$ age. This might be due to the vicinity of a large massif of charnockite emplaced at $\sim 520 \mathrm{Ma}$. The presence of this hot magmatic body may have reduced the cooling rate in the surrounding rocks during its solidification. There is no evidence of a correlation between $\mathrm{U}-\mathrm{Pb}$ and $\mathrm{Ar} / \mathrm{Ar}$ ages in the WMU and CPU, suggesting that the EAU underwent a specific thermotectonic evolution.

The variations in $\mathrm{U}-\mathrm{Pb}$ and $\mathrm{Ar} / \mathrm{Ar}$ ages support that, although not far from each other, some parts of the EAU started to crystallize and cooled down well before other parts. This 592 might be due to diachronic migration of granites generated in the anatectic middle crust. 593 However, considering the complex strain pattern mapped across the EAU (Cavalcante et al., 2013), the variation in thermal evolution in the EAU is in good agreement with a "channel- 
595 flow like" deformation during which, due to gravity forces, some parts of the anatectic core of 596 the belt were thrust upwards before or more efficiently than other parts (Cavalcante et al. 597 2018). The western EAU anatexites, in an initially shallower position, crystallized zircon and 598 reached the closure temperature of biotite before the initially deeper eastern EAU. The 599 regional variation in ages may also mean that the transcurrent fabric mapped in the eastern 600 EAU (Cavalcante et al., 2013; Figure 2) has been formed after the gently-dipping foliations of 601 the western part of the EAU, even if strain was, in both cases, accommodated by magmatic 602 flow in the anatexites.

603 The "channel-flow like" interpretation for the deformation of the EAU is in agreement 604 with the large-scale structure of the belt and with the crosscutting relationships of the contacts 605 between the different units (Figure 12), which suggest diachronic deformations under supra606 solidus temperature across the belt. The anatexites of the EAU cover discordantly the other 607 allochthonous units. In the northernmost part of the Araçuaí belt, they are directly atop the 608 para-autochthonous HT metasediments of the São Francisco craton (Figure 12a), while in the central part of the Araçuaí belt, the EAU is thrust over the subvertical contact between the western CPU and the higher temperature intermediate kinzigitic unit (Figure 12b). This

611 supports earlier thrusting of the intermediate kinzigitic unit over the CPU, then verticalization 612 of the contact and, finally, thrusting of the anatexites of the EAU onto the steeply-dipping 613 structures of the central and intermediate units. No evidence of significant solid-state 614 deformation associated with thrusting of the EAU over the other units has ever been observed 615 in the various EAU anatexites, which are solely characterized by a strong magmatic fabric. 616 This suggests that these events, although diachronic, occurred before full solidification of the 617 magmatic bodies in the different units and that, at all times, deformation was concentrated in 618 the partially molten (or crystallized) rocks.

\section{Conclusions}

21 new ${ }^{40} \mathrm{Ar} /{ }^{39} \mathrm{Ar}$ ages of amphibole, muscovite and biotite from 16 samples collected in 621 the central (CPU) and eastern (EAU) units of the Araçuaí belt, together with ${ }^{40} \mathrm{Ar} /{ }^{39} \mathrm{Ar}$ and U$622 \mathrm{~Pb}$ ages and P-T data previously published by our group (Vauchez et al., 2007; Petitgirard et 623 al., 2009; Mondou et al., 2012, Cavalcante et al., 2013, 2014, 2018) provides constrains on 624 the thermal history of the middle crust in the central part of the Araçuaí hot orogen. U-Pb 625 zircon ages support that by $\sim 600 \mathrm{Ma}$ the middle to lower crust, heated to temperatures of $626 \sim 800^{\circ} \mathrm{C}$, was already partially molten and that production of anatectic magmas persisted until $627 \sim 570 \mathrm{Ma}$ at least (Cavalcante et al., 2018). Most of the granodioritic/tonalitic magmatism of 
628 the CPU, as well as the synkinematic leucogranites within the mylonitic metasediments of the

629 WMU, has been emplaced during this period (Nalini et al., 2000a,b; Noce et al., 2000;

630 Petitgirard et al, 2009; Mondou et al., 2012; Gonçalves et al., 2014).

Altogether these data point to a protracted orogenic evolution marked by:

- Initiation of crustal thickening and heating of the middle crust at about $630 \mathrm{Ma}$,

- Heating of the middle crust to $\geq 800{ }^{\circ} \mathrm{C}$ and initiation of pervasive partial melting at $\sim 600 \mathrm{Ma}$,

- Partial melting remained active until at least $\sim 570 \mathrm{Ma}$; it affected the middle and lower crust and also the mantle,

- Slow cooling (3-5 $\left.{ }^{\circ} \mathrm{C} / \mathrm{Ma}\right)$ of the middle crust, which reached temperatures of $\sim 500{ }^{\circ} \mathrm{C}$ at $510-500 \mathrm{Ma}$ and of $\sim 300{ }^{\circ} \mathrm{C}$ at $\sim 480 \mathrm{Ma}$.

- Magmatic rocks maintained high melt fractions for several tens of Myr (>40 Myr) during which they accommodated most of the imposed deformation by magmatic flow. A rough estimate suggests that they reached the solidus temperature $\left(\sim 630^{\circ} \mathrm{C}\right)$ at $\sim 545-555 \mathrm{Ma}$.

- The anatexites of the EAU underwent a diachronic evolution: those from the northwestern part crystallized and cooled down earlier than those from the southeastern part. However, estimated cooling rates across the EAU are similar. This diachronic evolution is consistent with a "channel flow like" tectonic model compatible with the 3D deformation of anatexites substantiated by Cavalcante et al. $(2013,2018)$.

Such a protracted thermal evolution had major effects on the rheology of the orogenic crust, on the strain repartition across the belt, and thus on the tectonic evolution of the Araçuaí belt. During progressive heating of the orogenic crust (prograde metamorphism), deformation was already active and crustal thickening was accommodated in the metasedimentary sequence, but the microstructures recording these early stages of deformation are impossible to differentiate from those formed at the peak of metamorphism in presence of melt and during subsequent deformation under almost stable temperature conditions. Initiation of partial melting at $\sim 600 \mathrm{Ma}$ and syntectonic injection of large volumes of granodioritic/tonalitic magmas between 590 and 570 Ma strongly decreased the viscosity of the middle crust, allowing gravity-induced deformation to combine with far-field compressive forces to produce a 3D deformation regime (Cavalcante et al., 2013). This may explain that northwestwards, the tectonic flow recorded in the middle crust rotate from 
661 dominantly eastward onto the São Francisco craton to northward onto the Salvador craton 662 (e.g., Uhlein et al., 1998).

663 Similar ${ }^{40} \mathrm{Ar} /{ }^{39} \mathrm{Ar}$ cooling ages are obtained for biotite in both the Araçuaí belt in Eastern 664 Brazil and the West-Congo belt in Angola (Monié et al., 2012) despite the large differences in 665 the age of the orogenic climax and in tectonic evolution. This suggests that the late thermal 666 evolution in the Araçuaí-Ribeira orogeny is shared by the West-Congo - Cabo Frio belt 667 during the final stages of continental amalgamation. This might explain the late emplacement 668 of some atypical magmatic bodies (syenites, charnockites) in the Araçuaí belt.

Acknowledgements: We are indebted to Andréa Tommasi for her critical reading and 671 commenting of the successive versions of this manuscript. We warmly acknowledge Olivier 672 Vanderhaegue and an anonymous reviewer for their detailed reviews and their suggestions to 673 improve our manuscript. We also thank Carolina Cavalcante and Sylvain Petitgirard for their 674 important contribution to the study of the eastern anatectic and western mylonitic units, 675 respectively. This study benefited from funding by CAPES-COFECUB project Te 588/07 and 676 by FAPESP through grant 2005/56372-7. M.H.B.M. Hollanda thanks to CNPq for her 677 research grant. 
679

680

681

682

683

684

685

686

687

688

689

690

691

692

693

694

695

696

697

698

699

700

701

702

703

704

705

706

707

708

Ackerson, M.R., Mysen, B.O., Tailby, N.D. and Watson, E.B., 2018. Low-temperature crystallization of granites and the implications for crustal magmatism. Nature 559, 94-97.

Almeida, F.F.M., 1977. O Cráton do São Francisco. Revista Brasileira de Geociências 7, 349364.

Assumpção, M., Bianchi, M., Juliá, J., Dias, F.L., Sand França, G., Nascimento, R., Drouet, S., Pavão, C.G., Albuquerque, D.F. and Lopes, A.E.V., 2013. Crustal thickness map of Brazil: Data compilation and main features. Journal of South American Earth Sciences 43, 74-85.

Assumpção, M., Heintz, M., Vauchez, A. and Silva, M.E., 2006. Upper mantle anisotropy in SE and Central Brazil from SKS splitting: Evidence of asthenospheric flow around a cratonic keel. Earth and Planetary Science Letters 250, 224-240.

Beaumont, C., Jamieson, R. and Nguyen, M., 2010. Models of large, hot orogens containing a collage of reworked and accreted terranes. Canadian Journal of Earth Sciences 47, 485515.

Bento dos Santos, T.M., Munhá, J.M., Tassinari, C.C.G., Fonseca, P.E. and Dias Neto, C., 2010. Thermochronology of central Ribeira Fold Belt, SE Brazil: Petrological and geochronological evidence for long-term high temperature maintenance during Western Gondwana amalgamation. Precambrian Research 180, 285-298.

Bento dos Santos, T.M., Tassinari, C.C.G. and Fonseca, P.E., 2014. Garnet-biotite diffusion mechanisms in complex high-grade orogenic belts: Understanding and constraining petrological cooling rates in granulites from Ribeira Fold Belt (SE Brazil). Journal of South American Earth Sciences 56, 128-138.

Brandon, M.T., Roden-Tice, M.K. and Garver, J.I., 1998. Late Cenozoic exhumation of the Cascadia accretionary wedge in the Olympic Mountains, northwest Washington State. Geological Society of America Bulletin 110, 985-1009.

Braun, J., van der Beek, P. and Batt, G., 2006. Quantitative Thermochronology: Numerical Methods for the Interpretation of thermochronological data. Cambridge University Press, New York, 272 pp. 
Cavalcante, G.C.G., Egydio-Silva, M., Vauchez, A., Camps, P. and Oliveira, E., 2013. Strain distribution across a partially molten middle crust: Insights from the AMS mapping of the Carlos Chagas Anatexite, Araçuaí belt (East Brazil). Journal of Structural Geology 55, 79-100.

Cavalcante, G.C.G., Vauchez, A., Merlet, C., Egydio-Silva, M., Bezerra de Holanda, M.H. and Boyer, B., 2014. Thermal conditions during deformation of partially molten crust from TitaniQ geothermometry: rheological implications for the anatectic domain of the Araçuaí belt, eastern Brazil. Solid Earth 5, 1223-1242.

Clark, C., Fitzsimons, I.C.W., Healy, D. and Harley, S.L., 2011. How Does the Continental Crust Get Really Hot? Elements 7, 235.

Clark, C., Healy, D., Johnson, T., Collins, A.S., Taylor, R.J., Santosh, M. and Timms, N.E., 2015. Hot orogens and supercontinent amalgamation: A Gondwanan example from southern India. Gondwana Research 28, 1310-1328.

Cordani, U.G., Ramos, V.A., Fraga, L.M., Cegarra, M., Delgado, I., de Souza, K.G., Gomes, F.E.M. and Schobbenhaus, C., 2016. Tectonic Map of South America at 1/5 900000. CGMW-CPRM-SEGEMAR.

Cunningham, W.D., Marshak, S. and Alkmin, F.F., 1996. Structural style of basin inversion at mid-crustal levels: two transects in the internal zone of the Brasiliano Araçuaí belt, Minas Gerais, Brazil. Precambrian Research 77, 1-15.

Dahl, P.S., 1996. The effects of composition on retentivity of argon and oxygen in hornblende and related amphiboles: A field-tested empirical model. Geochimica et Cosmochimica Acta 60, 3687-3700.

Dodson, M.H., 1973. Closure temperature in cooling geochronological and petrological systems. Contributions to Mineralogy and Petrology 40, 259-274.

Egydio-Silva, M., Vauchez, A., Bascou, J. and Hippertt, J., 2002. High-temperature deformation in the Neoproterozoic transpressional Ribeira belt, southeast Brazil. Tectonophysics 352, 203-224.

Egydio-Silva, M., Vauchez, A., Raposo, M.I.B., Bascou, J. and Uhlein, A., 2005. Deformation regime variations in an arcuate transpressional orogen (Ribeira belt, SE Brazil) imaged by anisotropy of magnetic susceptibility in granulites. Journal of Structural Geology 27, 1750-1764. 
Egydio-Silva, M., Vauchez, A., Fossen, H., Gonçalves Cavalcante, G.C. and Xavier, B.C., 2018. Connecting the Araçuaí and Ribeira belts (SE - Brazil): Progressive transition from contractional to transpressive strain regime during the Brasiliano orogeny. Journal of South American Earth Sciences 86, 127-139.

England, P.C. and Thompson, A., 1986. Some thermal and tectonic models for crustal melting in continental collision zones. In: M.P. Coward and A.C. Ries (Editors), Collision Tectonics. Geol.Soc.Spec.Pub., pp. 83-94.

Gonçalves, L., Farina, F., Lana, C., Pedrosa-Soares, A.C., Alkmim, F. and Nalini Jr, H.A., 2014. New U-Pb ages and lithochemical attributes of the Ediacaran Rio Doce magmatic arc, Araçuaí confined orogen, southeastern Brazil. Journal of South American Earth Sciences 52, 129-148.

Guo, Z. and Wilson, M., 2012. The Himalayan leucogranites: Constraints on the nature of their crustal source region and geodynamic setting. Gondwana Research 22, 360-376.

Harley, S.L., 2004. Extending our understanding of Ultrahigh temperature crustal metamorphism. Journal of Mineralogical and Petrological Sciences 99, 140-158.

Harley, S.L., Thompson, P., Hensen, B.J. and Buick, I.S., 2002. Cordierite as a sensor of fluid conditions in high-grade metamorphism and crustal anatexis. Journal of Metamorphic Geology 20, 71-86.

Harris, N., Vance, D. and Ayres, M., 2000. From sediment to granite: timescales of anatexis in the upper crust. Chemical Geology 162, 155-167.

Harrison, T.M., Célérier, J., Aikman, A.B., Hermann, J. and Heizler, M.T., 2009. Diffusion of 40Ar in muscovite. Geochimica et Cosmochimica Acta 73, 1039-1051.

Harrison, T.M., Duncan, I. and McDougall, I., 1985. Diffusion of 40Ar in biotite: Temperature, pressure and compositional effects. Geochimica et Cosmochimica Acta 49, 2461-2468.

Hasui, Y., Carneiro, C.D.R. and Coimbra, A.M., 1975. The Ribeira folded belt. Revista Brasileira de Geociências 5, 257-266.

Heintz, M., Vauchez, A., Assumpção, M., Barruol, G. and Egydio-Silva, M., 2003. Shear Wave Splitting in SE Brazil : an Effect of Active or Frozen Upper Mantle Flow, or both? Earth and Planetary Science Letters 211, 79-95.

Högdahl, K., Majka, J., Sjöström, H., Nilsson, K.P., Claesson, S. and Konečný, P., 2012. Reactive monazite and robust zircon growth in diatexites and leucogranites from a hot, 
slowly cooled orogen: implications for the Palaeoproterozoic tectonic evolution of the central Fennoscandian Shield, Sweden. Contributions to Mineralogy and Petrology 163, 167-188.

Holdaway, M.J., Mukhopadhyay, B. and Dutrow, B.L., 1995. Thermodynamic properties of stoichiometric staurolite $\mathrm{H} 2 \mathrm{Fe} 4 \mathrm{Al} 18 \mathrm{Si} 8 \mathrm{O} 48$ and $\mathrm{H} 6 \mathrm{Fe} 2 \mathrm{Al} 18 \mathrm{Si} 8 \mathrm{O} 48$, American Mineralogist, pp. 520.

Huerta, A.D., Royden, L.H. and Hodges, K.V., 1998. The thermal structure of collisional orogens as a response to accretion, erosion, and radiogenic heating. Journal of Geophysical Research B: Solid Earth 103, 15287-15302.

Jamieson, R.A., Unsworth, M.J., Harris, N.B.W., Rosenberg, C.L. and Schulmann, K., 2011. Crustal Melting and the Flow of Mountains. Elements 7, 253-260.

Janots, E., Engi, M., Rubatto, D., Berger, A., Gregory, C. and Rahn, M., 2009. Metamorphic rates in collisional orogeny from in situ allanite and monazite dating. Geology 37, 11-14.

Le Breton, N. and Thompson, A.B., 1988. Fluid-absent (dehydration) melting of biotite in metapelites in the early stages of crustal anatexis. Contributions to Mineralogy and Petrology 99, 226-237.

McKenzie, D., Jackson, J. and Priestley, K., 2005. Thermal structure of oceanic and continental lithosphere. Earth and Planetary Science Letters 233, 337.

McDougall, I. and Harrison, T.M., 1999. Geochronology and Thermochronology by the ${ }^{40} \mathrm{Ar} /{ }^{39} \mathrm{Ar}$ Method, 2nd edition. Oxford University Press, New York, 269 pp.

Melo, M.G., Stevens, G., Lana, C., Pedrosa-Soares, A.C., Frei, D., Alkmim, F.F. and Alkmin, L.A., 2017. Two cryptic anatectic events within a syn-collisional granitoid from the Araçuaí orogen (southeastern Brazil): Evidence from the polymetamorphic Carlos Chagas batholith. Lithos 277, 51-71.

Michaut, C. and Jaupart, C., 2007. Secular cooling and thermal structure of continental lithosphere. Earth and Planetary Science Letters 257, 83-96.

Michaut, C. and Jaupart, C., 2011. Two models for the formation of magma reservoirs by small increments. Tectonophysics 500, 34-49.

Möller, A., Mezger, K. and Schenk, V., 2000. U-Pb dating of metamorphic minerals: PanAfrican metamorphism and prolonged slow cooling of high pressure granulites in Tanzania, East Africa. Precambrian Research 104, 123-146. 
803

804

805

806

807

808

809

810

811

812

813

814

815

816

817

818

819

820

821

822

823

824

825

826

827

828

829

830

831

832

833

834

Mondou, M., Egydio-Silva, M., Vauchez, A., Raposo, M.I.B., Bruguier, O. and Oliveira, A.F., 2012. Complex, 3D strain patterns in a synkinematic tonalite batholith from the Araçuaí Neoproterozoic orogen (Eastern Brazil): Evidence from combined magnetic and isotopic chronology studies. Journal of Structural Geology 39, 158-179.

Monié, P., Bosch, D., Bruguier, O., Vauchez, A., Rolland, Y., Nsungani, P. and Buta Neto, A., 2012. The Late Neoproterozoic/Early Palaeozoic evolution of the West Congo Belt of NW Angola: geochronological (U-Pb and Ar-Ar) and petrostructural constraints. Terra Nova 24, 238-247.

Morães, R., Nicollet, C., Barbosa, J.S.F., Fuck, R.A. and Sampaio, A.R., 2015. Applications and limitations of thermobarometry in migmatites and granulites using as an example rocks of the Araçuaí Orogen in southern Bahia, including a discussion on the tectonic meaning of the current results. Brazilian Journal of Geology 45, 517-539.

Morisset, C.-E., Scoates, J.S., Weis, D. and Friedman, R.M., 2009. U-Pb and 40Ar/39Ar geochronology of the Saint-Urbain and Lac Allard (Havre-Saint-Pierre) anorthosites and their associated Fe-Ti oxide ores, Québec: Evidence for emplacement and slow cooling during the collisional Ottawan orogeny in the Grenville Province. Precambrian Research $174,95-116$.

Nabelek, P.I. and Liu, M., 2004. Petrologic and thermal constraints on the origin of leucogranites in collisional orogens. Transactions of the Royal Society of Edinburgh: Earth Sciences 95, 73-85.

Nabelek, P.I., Whittington, A.G. and Hofmeister, A.M., 2010. Strain heating as a mechanism for partial melting and ultrahigh temperature metamorphism in convergent orogens: Implications of temperature-dependent thermal diffusivity and rheology. Journal of Geophysical Research 115, B12417.

Nalini, H.A., Bilal, E. and Correia Neves, J.M., 2000a. Syn-collisional peraluminous magmatism in the Rio Doce region: mineralogy, geochemistry and isotopic data of the neoproterozoic Urucum suite (eastern Minas Gerais state, Brazil). Revista Brasileira de Geociências 30, 120-125.

Nalini, H.A., Bilal, E., Paquette, J.-L., Pin, C. and Machado, R., 2000b. Géochronologie U-Pb et géochimie isotopique $\mathrm{Sr}-\mathrm{Nd}$ des granitoïdes néoprotérozoïques des suites Galiléia et Urucum, vallée du Rio Doce, Sud-Est du Brésil. Comptes Rendus de l'Académie des Sciences - Series IIA - Earth and Planetary Science 331, 459-466. 
Nalini, H.A., Machado, R. and Bilal, E., 2015. Petrogênese e tectônica da suíte granítica Urucum, Vale do Rio Doce (Minas Gerais - Brasil): um exemplo de magmatismo sin- a tardi-colisional associado a zonas de cisalhamento direcionais de alto ângulo. Brazilian Journal of Geology 45, 127-141.

Narduzzi, F., Farina, F., Stevens, G., Lana, C. and Nalini, H.A., 2017. Magmatic garnet in the Cordilleran-type Galiléia granitoids of the Araçuaí belt (Brazil): Evidence for crystallization in the lower crust. Lithos 282, 82-97.

Nelson, K.D., Zhao, W., Brown, L.D., Kuo, J., Che, J., Liu, X., Klemperer, S.L., Makovsky, Y., Meissner, R., Mechie, J., Kind, R., Wenzel, F., Ni, J., Nabelek, J., Chen, L., Tan, H., Wei, W., Jones, A.G., Booker, J., Unsworth, M., Kidd, W.S.F., Hauck, M., Alsdorf, D., Ross, A., Cogan, M., Wu, C., Sandvol, E.A. and Edwards, M., 1996. Partially molten middle crust beneath southern Tibet; synthesis of Project INDEPTH results. Science 274, 1684-1688.

Neves, S.P., Tommasi, A. and Vauchez, A., 2008. Intraplate continental deformation: Influence of a heat-producing layer in the lithospheric mantle. Earth and Planetary Science Letters.

Noce, C.M., Macambira, M.J.B. and Pedrosa Soares, A.C., 2000. Chronology of neoproterozoic-cambrian granitic magmatism in the Araçuaí belt, eastern Brazil, based on single zircon evaporation dating. Revista Brasileira de Geociências 30, 20-29.

Oliveira, M.-J.R., Pinto, C.P., Féboli, W.L. and Alves dos Santos, R., 2000. Projeto Leste Relatorio mapa integrado 1:500.000 - Geologia estrutural e tectônica, CPRM - COMIG, Belo Horizonte.

Pattison, D.R.M., Chacko, T., Farquhar, J. and McFarlane, C.R.M., 2003. Temperatures of Granulite-facies Metamorphism: Constraints from Experimental Phase Equilibria and Thermobarometry Corrected for Retrograde Exchange. Journal of Petrology 44, 867-900.

Pedrosa-Soares, A.C., Noce, C.M., Alkmim, F.F.d., Silva, L.C.d., Babinski, M., Cordani, U. and Castañeda, C., 2007. Orógeno Araçuaí: síntese do conhecimento 30 anos após Almeida 1977. Geonomos 15, 1-16.

Petitgirard, S., Vauchez, A., Egydio-Silva, M., Bruguier, O., Camps, P., Monié, P., Babinski, M. and Mondou, M., 2009. Conflicting structural and geochronological data from the Ibituruna quartz-syenite (SE Brazil): Effect of protracted "hot" orogeny and slow cooling rate? Tectonophysics $477,174-196$. 
Peucat, J.J., Ménot, R.P., Monnier, O. and Fanning, C.M., 1999. The Terre Adélie basement in the East-Antarctica Shield: geological and isotopic evidence for a major 1.7Ga thermal event; comparison with the Gawler Craton in South Australia. Precambrian Research 94, 205-224.

Reiners, P.W. and Brandon, M.T., 2006. Using thermochronology to understand orogenic erosion. Annual Review of Earth and Planetary Sciences 34, 419-466.

Richter, F., Lana, C., Stevens, G., Buick, I., Pedrosa-Soares, A.C., Alkmim, F.F. and Cutts, K., 2016. Sedimentation, metamorphism and granite generation in a back-arc region: Records from the Ediacaran Nova Venécia Complex (Araçuaí Orogen, Southeastern Brazil). Precambrian Research 272, 78-100.

Rosenberg, C.L. and Handy, M.R., 2005. Experimental deformation of partially melted granite revisited; implications for the continental crust. Journal of Metamorphic Geology 23, 19-28.

Rosenberg, C.L., Medvedev, S. and Handy, M.R., 2007. On the effects of melting on continental deformation and faulting. In: M. Handy, G. Hirth and N. Hovius (Editors), Tectonic Faults: Agents of Change on a Dynamic Earth. Dahlem Workshop Report, MIT Press, pp. 357-402.

Schmitt, R.S., Trouw, R.A.J., Van Schmus, W.R. and Pimentel, M.M., 2004. Late amalgamation in the central part of West Gondwana: new geochronological data and the characterization of a Cambrian collisional orogeny in the Ribeira Belt (SE Brazil). Precambrian Research 133, 29-61.

Siga Jr, O., Cordani, U.G., Basei, M.A.S., Teixeira, W., Kawashita, K. and Van Schmus, W.R., 1987. Contribuição ao estudo geológico e geocronológico da porção nordeste de Minas Gerais, Anais. IV Simpósio de Geologia de Minas Gerais, pp. 29-44.

Silva, L.C., Armstrong, R., Noce, C.M., Carneiro, M.A., Pimentel, M.M., Pedrosa-Soares, A.C., Leite, C.A., Vieira, V.S., Silva, M.A., Paes, V.J.C. and Cardoso Filho, J.M., 2002. Reavaliação da evolução geológica em terrenos pré-cambrianos brasileiros com base em novos dados U-Pb Shrimp, parte II: Orógeno Araçuaí, cinturão mineiro e cráton São Francisco meridional. Revista Brasileira de Geociências 32, 513-528.

Silva, L.C., McNaughton, N.J., Armstrong, R., Hartmann, L.A. and Fletcher, I.R., 2005. The Neoproterozoic Mantiqueira Province and its African connections; a zircon-based U/Pb 
geochronologic subdivision for the Brasiliano/Pan-African systems of orogens. Precambrian Research 136, 203-240.

Trompette, R., Uhlein, A., da Silva, M.E. and Karmann, I., 1992. The Brasiliano São Francisco craton revisited (central Brazil). Journal of South American Earth Sciences 6, 49-57.

Turlin, F., Deruy, C., Eglinger, A., Vanderhaeghe, O., André - Mayer, A.S., Poujol, M., Moukhsil, A. and Solgadi, F., 2018. A 70 Ma record of suprasolidus conditions in the large, hot, long - duration Grenville Orogen. Terra Nova 30, 233-243.

Uhlein, A., Egydio-Silva, M., Bouchez, J.L. and Vauchez, A., 1998. The Rubim Pluton (Minas Gerais, Brazil): a petrostructural and magnetic fabric study. Journal of South American Earth Sciences 11, 179-189.

Uhlein, A., Trompette, R.R., Egydio-Silva, M. and Vauchez, A., 2007. A glaciação sturtiana ( 750 ma), a estrutura do rifte Macaúbas-Santo Onofre e a estratigrafia do grupo Macaúbas, faixa Araçuaí. Geonomos 15-1, 106.

Vanderhaeghe, O., 2009. Migmatites, granites and orogeny: Flow modes of partially-molten rocks and magmas associated with melt/solid segregation in orogenic belts. Tectonophysics 477, 119-134.

Vanderhaeghe, O., Medvedev, S., Fullsack, P., Beaumont, C. and Jamieson, R.A., 2003. Evolution of orogenic wedges and continental plateaux: insights from crustal thermalmechanical models overlying subducting mantle lithosphere. Geophysical Journal International 153, 27-51.

Vanderhaeghe, O. and Teyssier, C., 2001a. Crustal-scale rheological transitions during lateorogenic collapse. Tectonophysics 335, 211-228.

Vanderhaeghe, O. and Teyssier, C., 2001b. Partial melting and flow of orogens. Tectonophysics 342, 451-472.

Vauchez, A., Tommasi, A. and Egydio-Silva, M., 1994. Self-indentation of continental lithosphere. Geology 22, 967-970.

Vauchez, A., Egydio-Silva, M., Babinski, M., Tommasi, A., Uhlein, A. and Liu, D., 2007. Deformation of a pervasively molten middle-crust: Insights from the neoproterozoic Araçuaí-Ribeira orogen (SE Brazil). Terra Nova 19, 278-286.

Vauchez, A., Tommasi, A. and Mainprice, D., 2012. Faults (shear zones) in the Earth's mantle. Tectonophysics 558-559, 1-27. 
930 Vielzeuf, D. and Holloway, J.R., 1988. Experimental determination of the fluid-absent 931 melting relations in the pelitic system. Contributions to Mineralogy and Petrology 98, $932 \quad 257-276$.

933 Weinberg, R.F. and Hasalová, P., 2015. Water-fluxed melting of the continental crust: A 934 review. Lithos 212, 158-188.

935 Whittington, A.G., Hofmeister, A.M. and Nabelek, P.I., 2009. Temperature-dependent 936 thermal diffusivity of the Earth/'s crust and implications for magmatism. Nature 458, $937 \quad 319-321$.

938 Zeck, H.P., Monié, P., Villa, I.M. and Hansen, B.T., 1992. Very high rates of cooling and 939 uplift in the Alpine belt of the Betic Cordilleras, southern Spain. Geology 20, 79-82.

940 Zhang, H., Harris, N., Parrish, R., Kelley, S., Zhang, L., Rogers, N., Argles, T. and King, J., 941 2004. Causes and consequences of protracted melting of the mid-crust exposed in the 942 North Himalayan antiform. Earth and Planetary Science Letters 228, 195-212. 


\begin{tabular}{|c|c|c|c|c|c|c|c|c|}
\hline \multirow{2}{*}{ Sample number and type } & \multirow{2}{*}{$\begin{array}{c}\begin{array}{c}\mathbf{U} / \mathbf{P b} M y r \\
\left(*={ }^{207} \mathrm{~Pb} /{ }^{206} \mathrm{~Pb}\right)\end{array} \\
\boldsymbol{Z r} \boldsymbol{r}\end{array}$} & \multicolumn{3}{|c|}{${ }^{40} \mathrm{Ar} /{ }^{39} \mathrm{Ar} M y r$} & \multicolumn{3}{|c|}{ Closing $\mathbf{T}{ }^{\circ} \mathrm{C}$} & \multirow{2}{*}{$\begin{array}{c}\text { Cooling } \\
\text { rate }{ }^{\circ} \mathrm{C} / \mathrm{My}\end{array}$} \\
\hline & & $A m$ & $B t$ & $M s$ & $A m$ & $B t$ & $M s$ & \\
\hline western mylonitic unit & \multicolumn{4}{|c|}{ All data from (1) } & & & & \\
\hline AR-684 leucocratic melt & $577 \pm 9$ & & & & & & & \\
\hline AR-935 leucocratic melt & $578 \pm 3^{*}$ & & & & & & & \\
\hline AR-562 Mylonite & & $501 \pm 5$ & $474 \pm 5$ & & $488 \pm 7$ & $310 \pm 11$ & & $\sim 3 / 8$ \\
\hline AR-86 leucocratic melt & & & $468 \pm 4$ & & & $318 \pm 12$ & & \\
\hline AR-414 Ibituruna syenite & $530 \pm 1$ & $505 \pm 5$ & & & $485 \pm 6$ & & & \\
\hline $\begin{array}{l}\text { Contact zone } \\
\text { Derribadinha }\end{array}$ & All data from (2) & & This work & & & & & \\
\hline AR-264 Tonalite & $581 \pm 4$ & & & & & & & \\
\hline AR-590 Tonalite & & $549 \pm 6$ & $532 \pm 5$ & & $513 \pm 7$ & $288 \pm 9$ & & $7 / 13$ \\
\hline AR-940 leucocratic melt & $587 \pm 5$ & & & & & & & \\
\hline AR-87 leucocratic melt & $579 \pm 8$ & & & & & & & \\
\hline AR-1057 Tonalite & $583 \pm 4 *$ & $542 \pm 8$ & $508 \pm 5$ & & $521 \pm 8$ & $293 \pm 8$ & & $5.6 / 6.6$ \\
\hline Central plutonic unit & All data from (2) & & This work & & & & & \\
\hline AR-1009 SV To/Gd & & $501 \pm 9$ & $490 \pm 5$ & & $526 \pm 6$ & $321 \pm 9$ & & \\
\hline AR-800 SV To/Gd & $582 \pm 6^{*}$ & & $485 \pm 5$ & & & $320 \pm 10$ & & 4.4 \\
\hline AR-968 SV To/Gd & $585 \pm 7$ & & & & & & & \\
\hline AR-957 Wolf leucogranite & $585 \pm 4$ & & $492 \pm 6$ & & & $326 \pm 5$ & & 4.6 \\
\hline AR-787 Galiléia To/Gd & $582 \pm 6$ & & & & & & & \\
\hline AR-705 Galiléia To/Gd & $579 \pm 4$ & & $475 \pm 4$ & & & $311 \pm 9$ & & 4.4 \\
\hline AR-815 Galiléia To/Gd & $583 \pm 4$ & & & & & & & \\
\hline AR-717 Galiléia To/Gd & $581 \pm 4 *$ & $500 \pm 5$ & $481 \pm 5$ & & $517 \pm 4$ & $311 \pm 9$ & & $2.9 / 12$ \\
\hline AR-747 Galiléia To/Gd & & & $482 \pm 4$ & & & $325 \pm 6$ & & \\
\hline AR-722 orthogneiss & $2103 \pm 11$ & & $484 \pm 5$ & & & $307 \pm 5$ & & \\
\hline AR-648 Palmital granite & & & $484 \pm 5$ & $488 \pm 5$ & & $306 \pm 6$ & $416 \pm 4$ & M-B:27 \\
\hline Eastern anatectic unit & $\begin{array}{c}\text { All data from (3) } \\
\text { except AR548 }\end{array}$ & & This work & & & & & \\
\hline AR-408 Diatexite & $597 \pm 8$ & & & & & & & \\
\hline AR-455 Anatectic granite & $594 \pm 4$ & & & & & & & \\
\hline AR-1133 Anatectic granite & $597 \pm 3$ & & $486 \pm 4$ & & & $307 \pm 5$ & & 4.4 \\
\hline AR-1145 Diatexite & $593 \pm 3$ & & $477 \pm 4$ & & & $328 \pm 3$ & & 4.1 \\
\hline AR-1315 Anatectic granite & $597 \pm 4$ & & & & & & & \\
\hline AR-664 Anatectic granite & $589 \pm 6$ & & $474 \pm 4$ & & & $307 \pm 5$ & & 4.1 \\
\hline AR- 1349 metatexite & $583 \pm 5$ & & $476 \pm 4$ & & & $323 \pm 3$ & & 4.3 \\
\hline AR-1358 Anatectic granite & $585 \pm 4$ & & & & & & & \\
\hline AR-535 Anatectic granite & $575 \pm 3$ & & $459 \pm 4$ & & & $338 \pm 7$ & & 3.3 \\
\hline AR-1119 Diatexite & $578 \pm 4$ & & & & & & & \\
\hline AR-1332 Anatectic granite & $572 \pm 9$ & & & & & & & \\
\hline AR-548 Anatectic granite & $575 \pm 4(4)$ & & $72 \pm 4(1)$ & & & $315 \pm 5$ & & 3.9 \\
\hline AR-1370 Anatectic granite & $572 \pm 4$ & & $469 \pm 4$ & & & $316 \pm 4$ & & 3.9 \\
\hline
\end{tabular}

Table 1: Summary of U-Pb and ${ }^{40} \mathrm{Ar} /{ }^{39} \mathrm{Ar}$ ages obtained from rocks collected in the Central Araçuaí belt. Samples are organized from West to East. (1) is for ages published in Petitgirard et al. (2009), (2) for those published in Mondou et al., (2012), (3) for those 
published in Cavalcante et al., 2018 and (4) for those published in Vauchez et al., 2007. The last column shows individual cooling rates calculated for samples for which $\mathrm{U}-\mathrm{Pb}$ and ${ }^{40} \mathrm{Ar} /{ }^{39} \mathrm{Ar}$ ages of amphibole and/or biotite have been obtained, and for which an initial temperature of the country-rock may be inferred (for sample AR-562 and AR-590 an age of $578 \mathrm{Ma}$ and $582 \mathrm{Ma}$ respectively has been assumed taking into account their vicinity and similarity with dated samples). Cooling rates are indicated as: above closing $\mathrm{T}$ of amphibole/ between amphibole and biotite closing T. For sample AR-648, MB is for cooling rate between muscovite and biotite closing $\mathrm{T}$. 


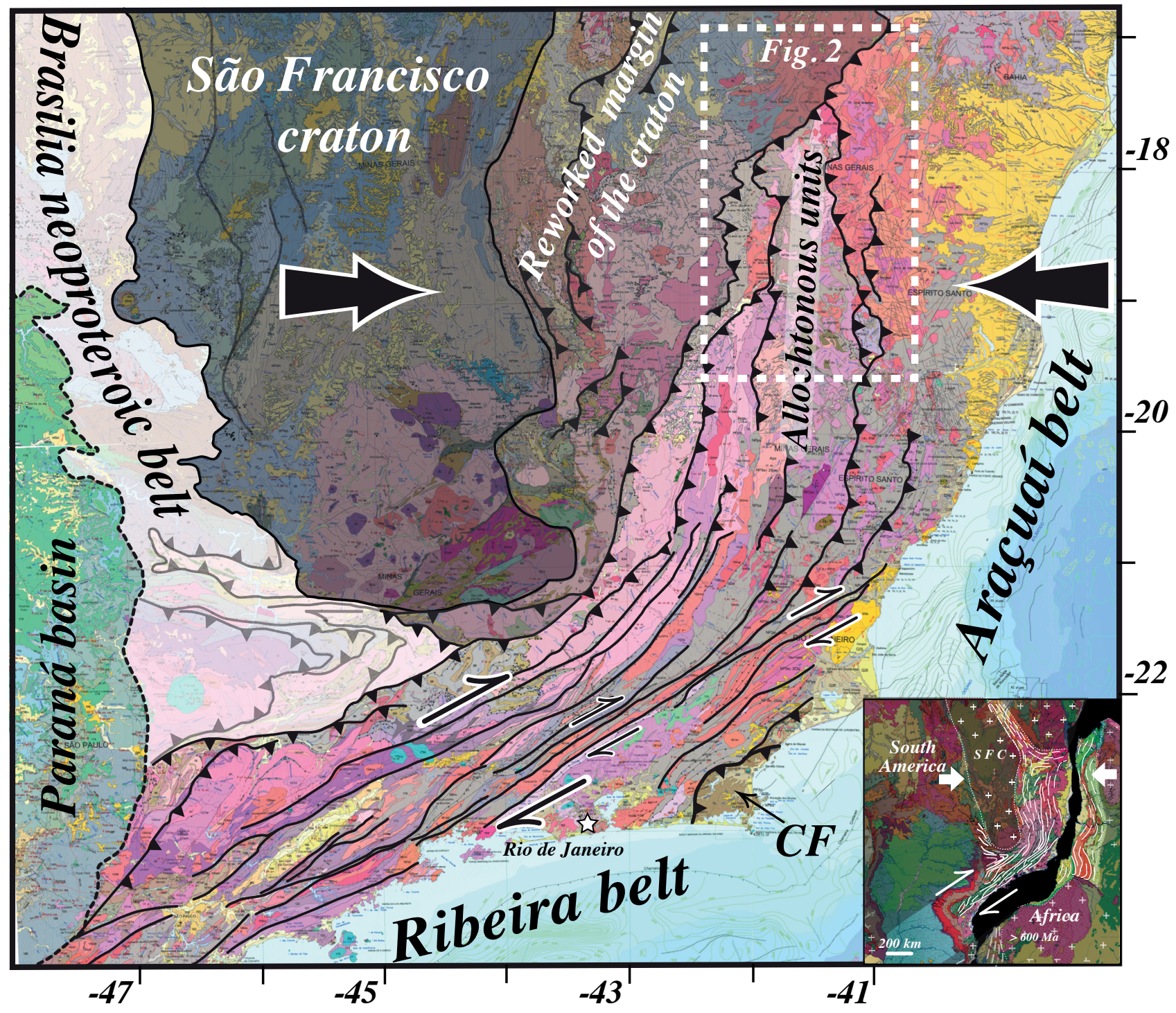

Figure 1: Schematic map of the neoproterozoic tectonic belts in eastern Brazil. The Brasilia belt is docked against the western and southwestern boundaries of the São Francisco (SF) craton. The Araçuaí and Ribeira belts formed along the eastern and southeastern boundary of the craton. The transition between these two orogenic segments, marked by a clear change in tectonic regime from contractional to tranpressional, is correlated with the southern termination of the craton. The eastern part of the São Francisco craton was strongly remobilized during the formation of the Araçuaí belt. Deformation in the Cabo Frio tectonic domain (CF) is younger than in the Araçuaí-Ribeira belt and likely represents the westernmost part of the early Cambrian Angola-Congo orogen. The underlying tectonic map is from (Cordani et al., 2016). The area delimited by doted white lines shows the location of Figure 2. Insert at the lower right corner is a reconstitution of the Ribeira-Araçuaí and Congo orogens before the South Atlantic opening (Vauchez et al., 2007). 


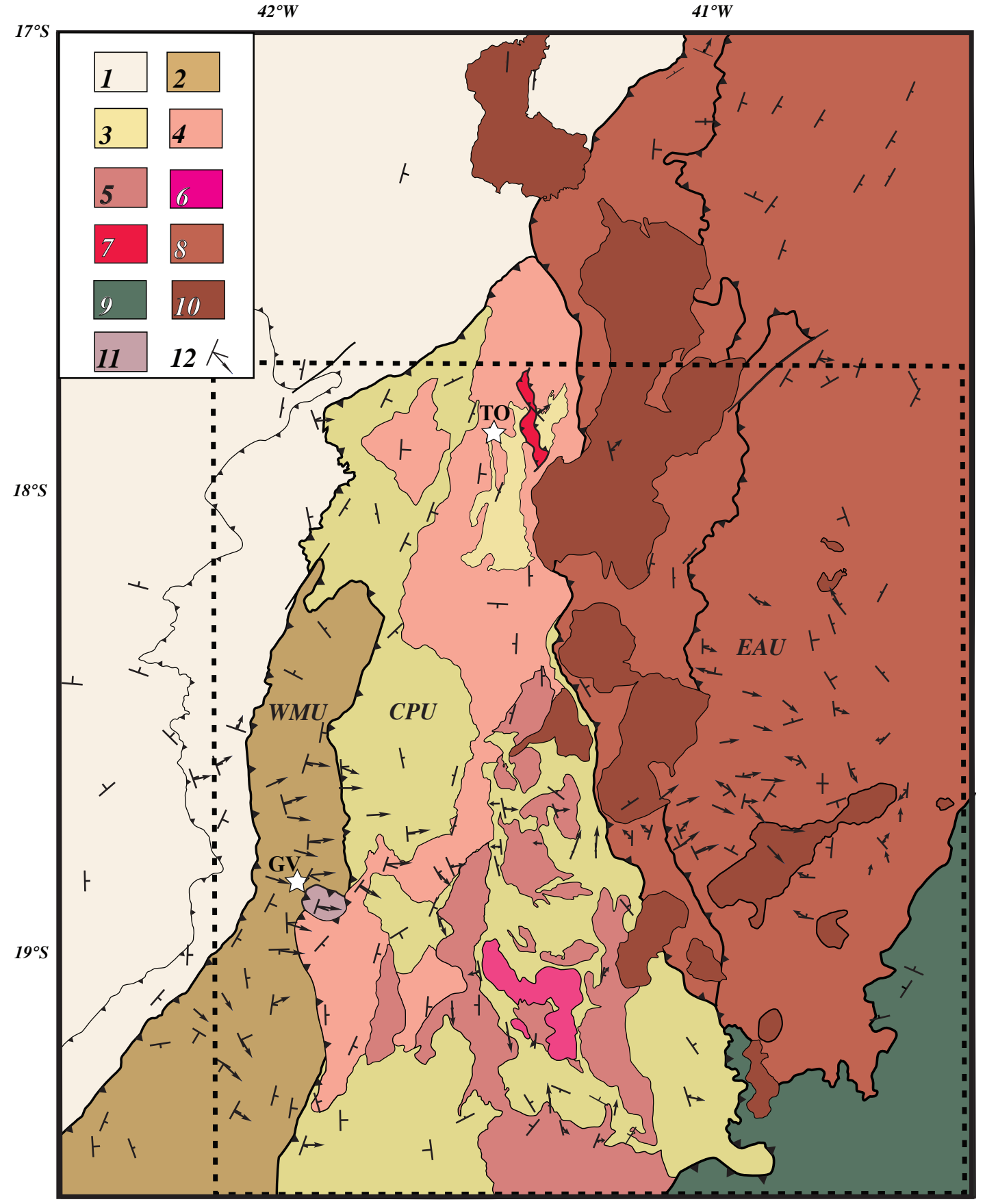

Figure 2: Simplified map of the central Araçuaí belt modified from Vauchez et al., 2007 showing (1) the para-autochthonous cover of the São Francisco cratons and the three allochthonous units: the western mylonitic unit (WMU, 2), the Central Plutonic Unit (CPU, 3-7) and the Eastern Anatectic Unit (EAU, 8-9). In the CPU, (3) is for metasediments, (4) for the "São Vitor" tonalite/granodiorite, (5) for the "Galileia" tonalite/granodiorite, (6) for the "Palmital" aluminous granite, (7) for the "Wolff" leucogranite. In the EAU: (8) anatexites and (9) kinzigites. (10) is the late "Padre Paraíso" charnockite. (11) foliation and lineation either measured in the field or inferred from AMS (Petitgirard et al., 2009; Mondou et al., 2012; Cavalcante et al., 2013). 

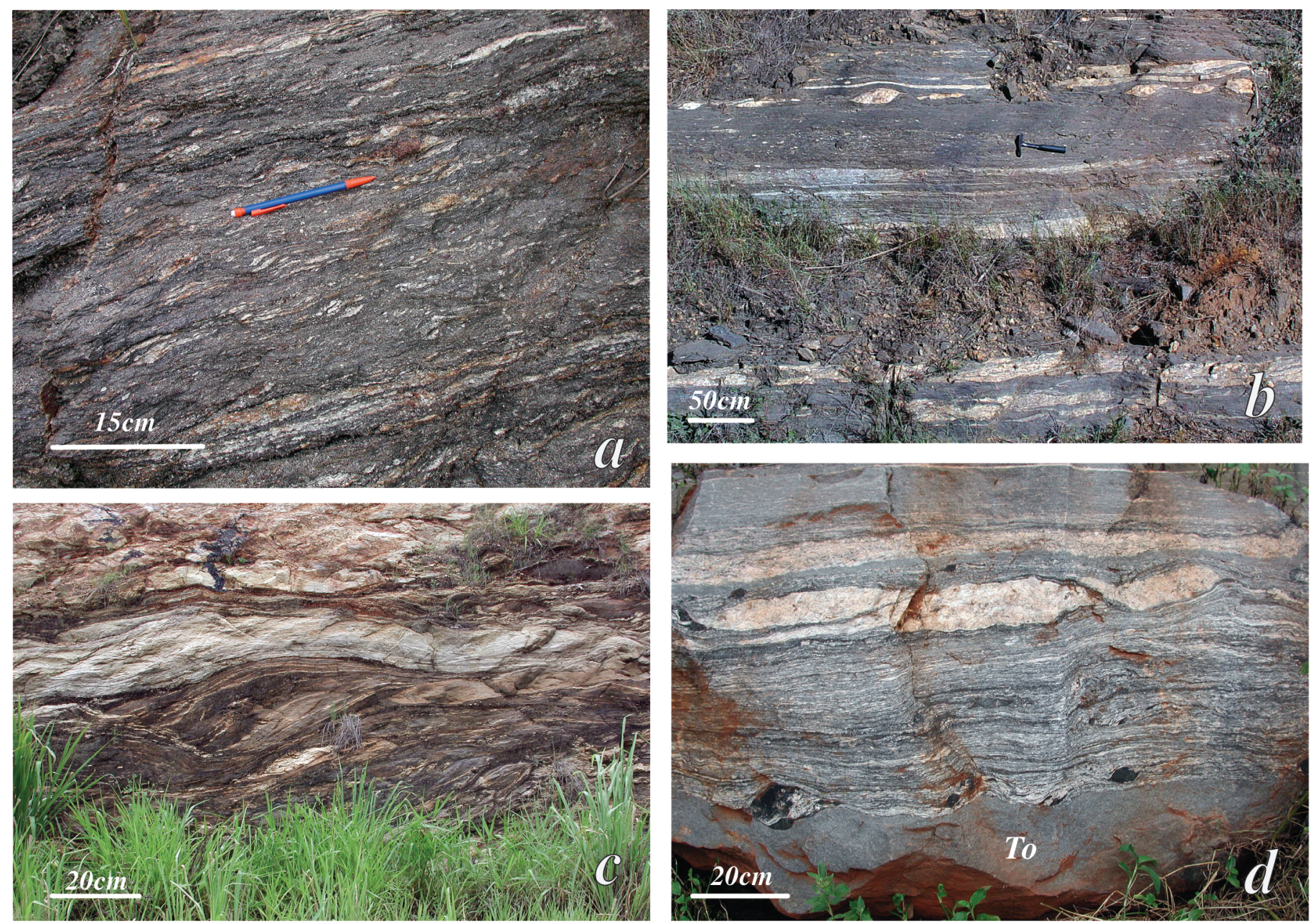

Figure 3: Typical outcrops of the Western Mylonitic Unit (a-c) and of its boundary with the Central Plutonic Unit (d). For the four pictures West is on the right. a-c show metasediments injected by leucocratic granite and shear criteria that indicate top-to-west sense of shear. In (a) lenses are leucogranite. (d) shows intercalations of leucogranite, migmatitic metasediments, tonalite (To) free of solid-state deformation and several asymmetric black lenses resulting from the disruption of an amphibolite layer. 


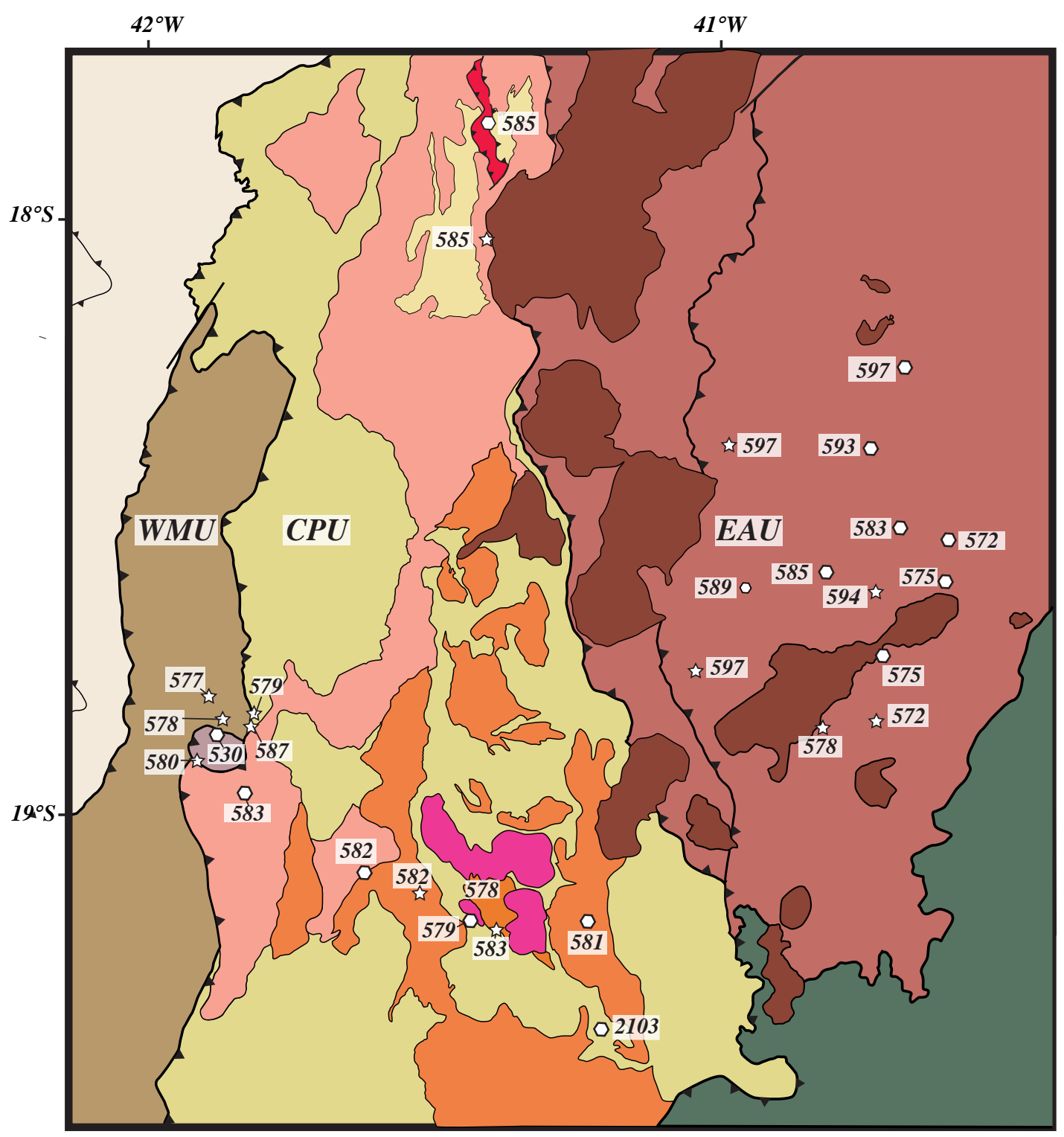

Figure 4: Location and $\mathrm{U}-\mathrm{Pb}$ ages (Ma) of zircons used in this study. Results (and references) are summarized in table 1. 

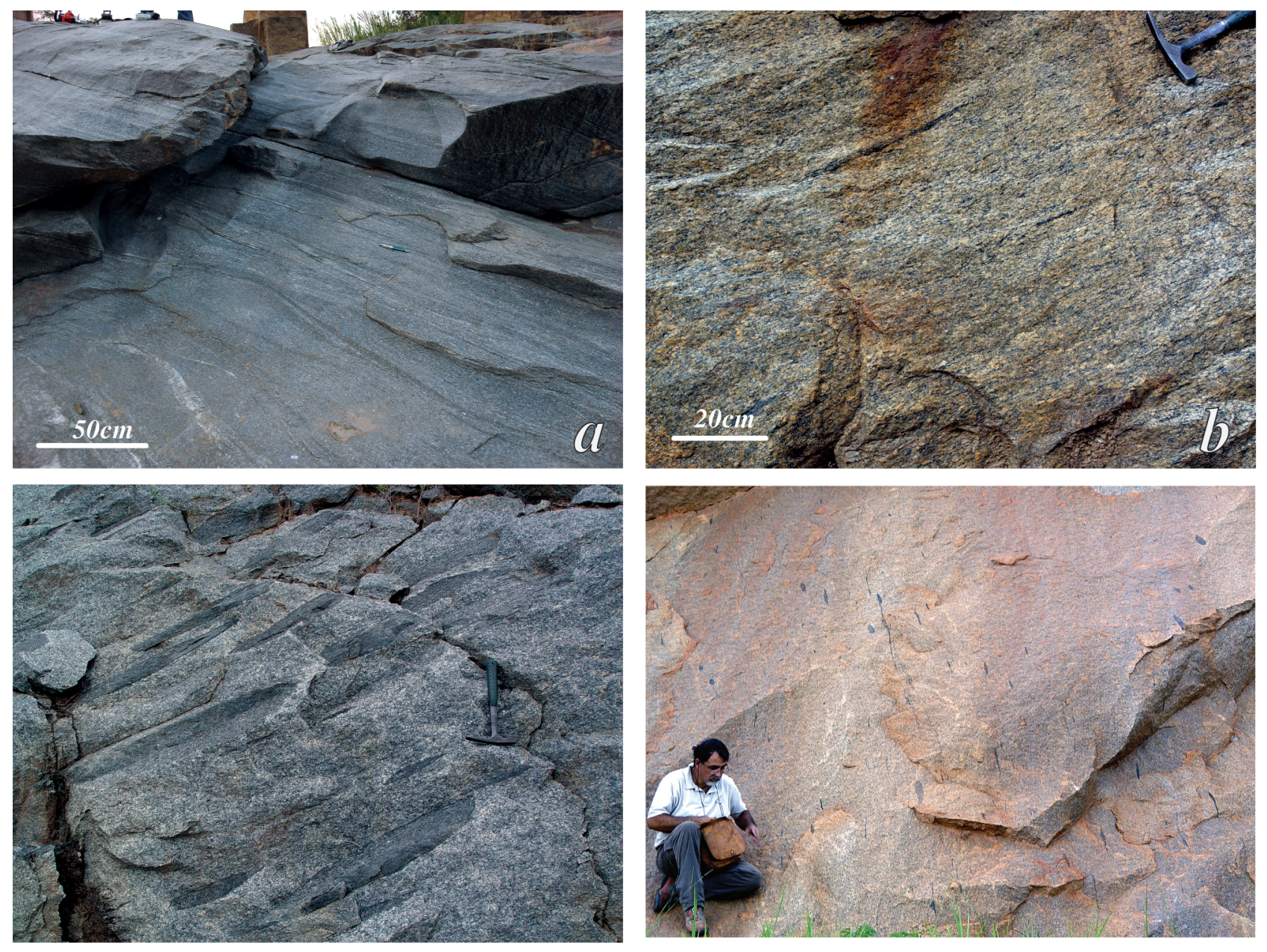

Figure 5: Pictures of outcrops typical of the Central Plutonic Unit. Tonalites/Granodiorites showing a well-developed magmatic foliation, gently-dipping in the western CPU (a-b) and that progressively becomes subvertical eastward (c-d). In (c) the subvertical magmatic foliation is underlined by elongated dioritic lenses and in (d) by lenses and discontinuous layers of biotite rich granite. 

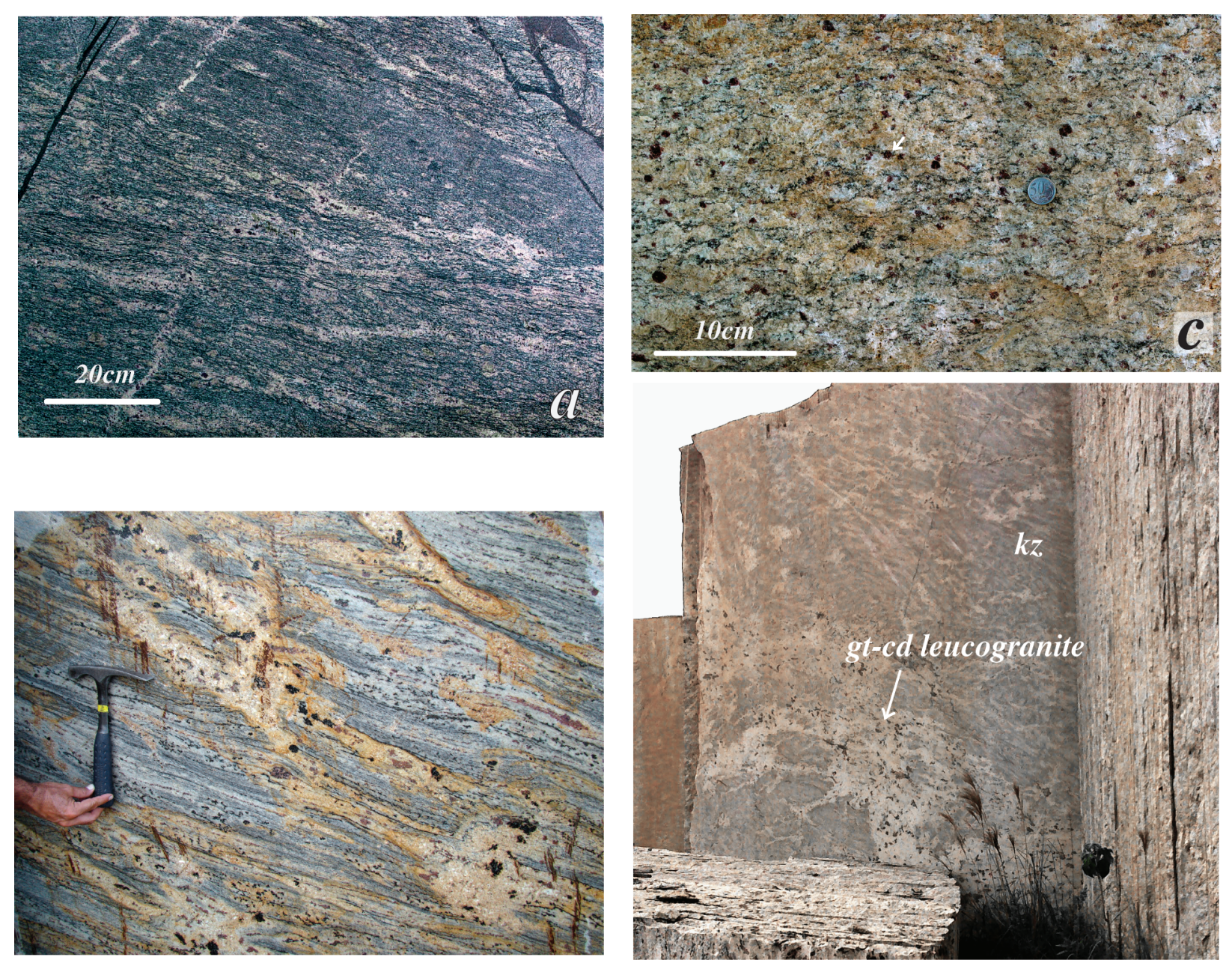

Figure 6: Pictures of outcrops typical of the Eastern Anatectic Unit: metatexites (a), diatexites (b) and garnet-rich leucocratic granite (c), all displaying a well-developed foliation, which is magmatic in the leucosome and solid-state in the restitic parts (when present). (d) shows the anatectic kinzigites $(\mathrm{kz})$ at the eastern boundary of the EAU, in which leucogranitic melt focus and forms lenses and veins. Dark lenses in the leucogranite contains garnet + biotite \pm cordierite. 


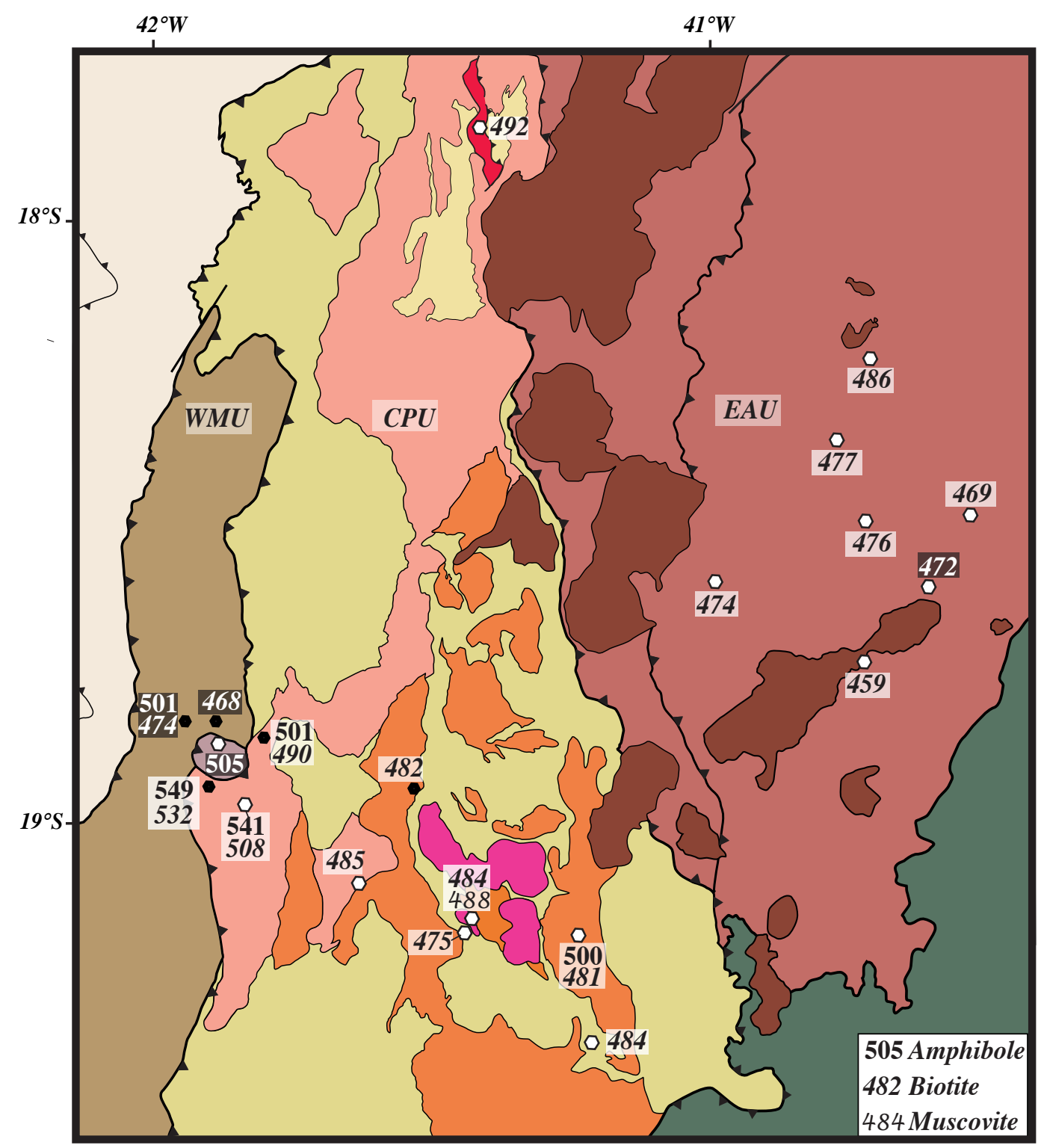

Figure 7 : Location and ${ }^{40} \mathrm{Ar} /{ }^{39} \mathrm{Ar}$ ages of amphibole, biotite and muscovite used in this study. Numbers in black are ages obtained in this study and those in white are previously published ${ }^{40} \mathrm{Ar} /{ }^{39} \mathrm{Ar}$ ages (4 samples). Diagrams for newly dated samples are shown on Figures 8 and 9. Analytical data are available in supplementary material \#3 and \#4. 

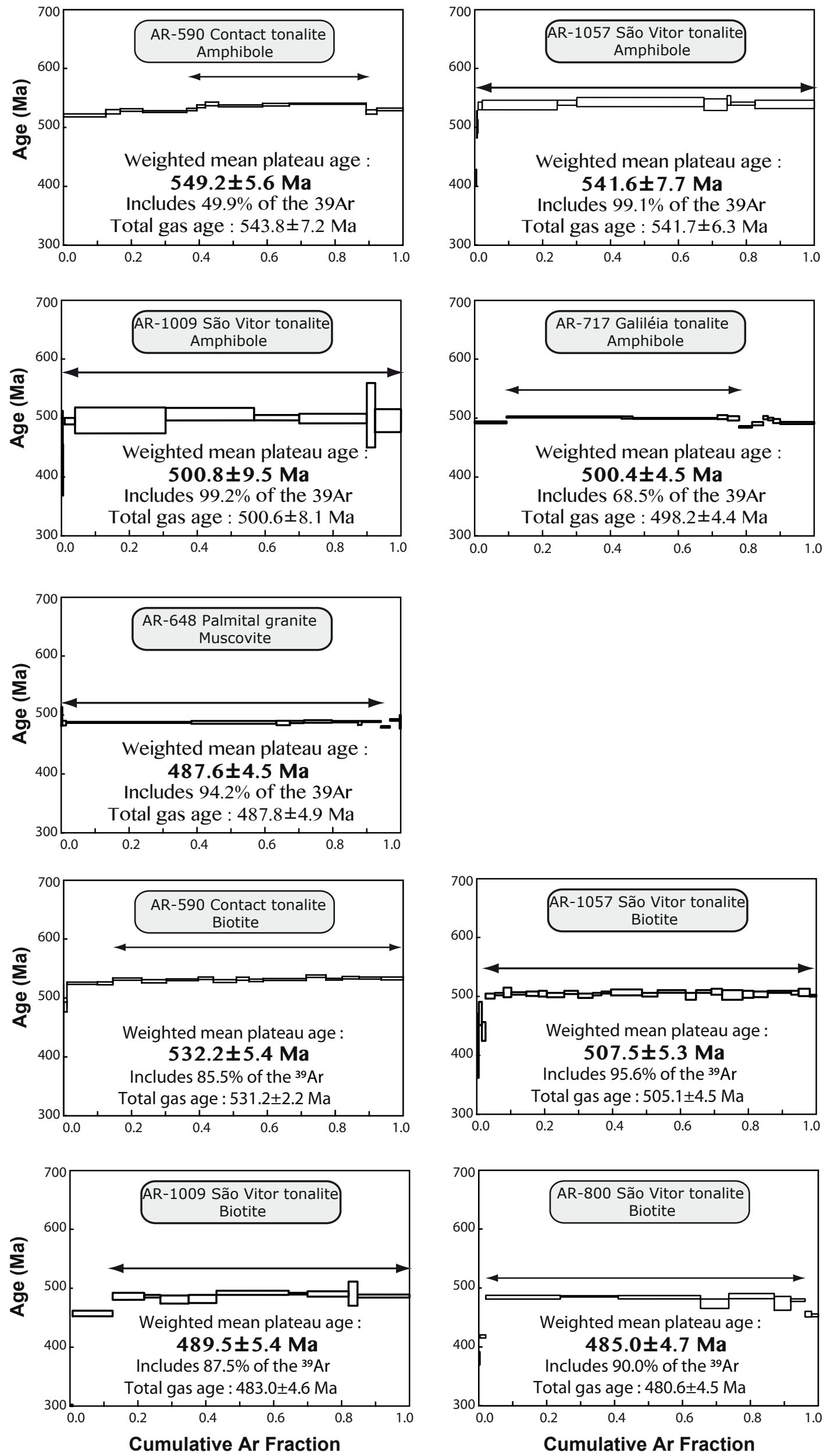

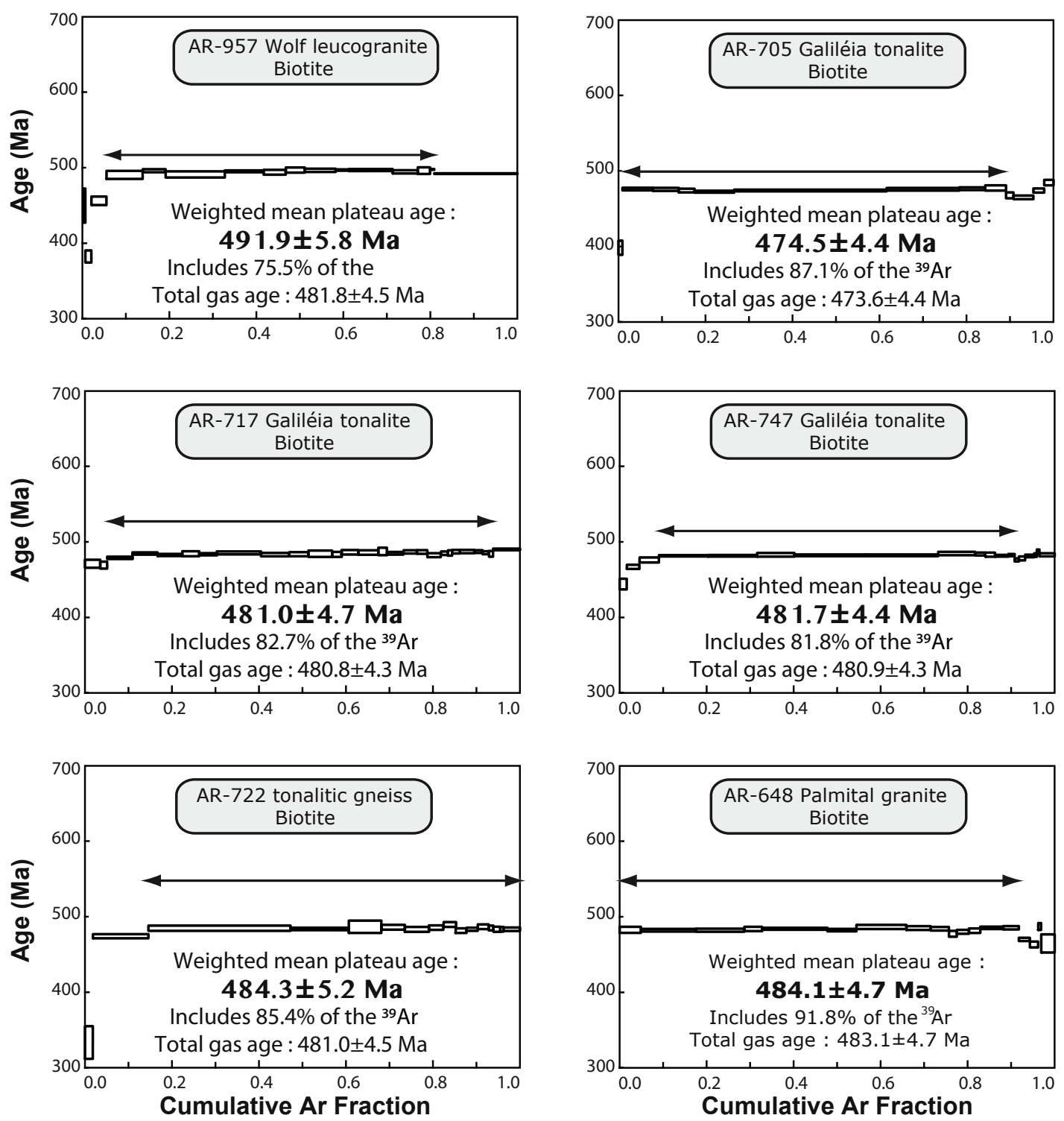

Figure $8:{ }^{40} \mathrm{Ar} /{ }^{39} \mathrm{Ar}$ diagrams for amphibole, muscovite and biotite from samples collected in the Central Plutonic Unit. Diagrams are organized by mineral and for samples from West to East. Analytical data and methodology are available in supplementary material \#3. 

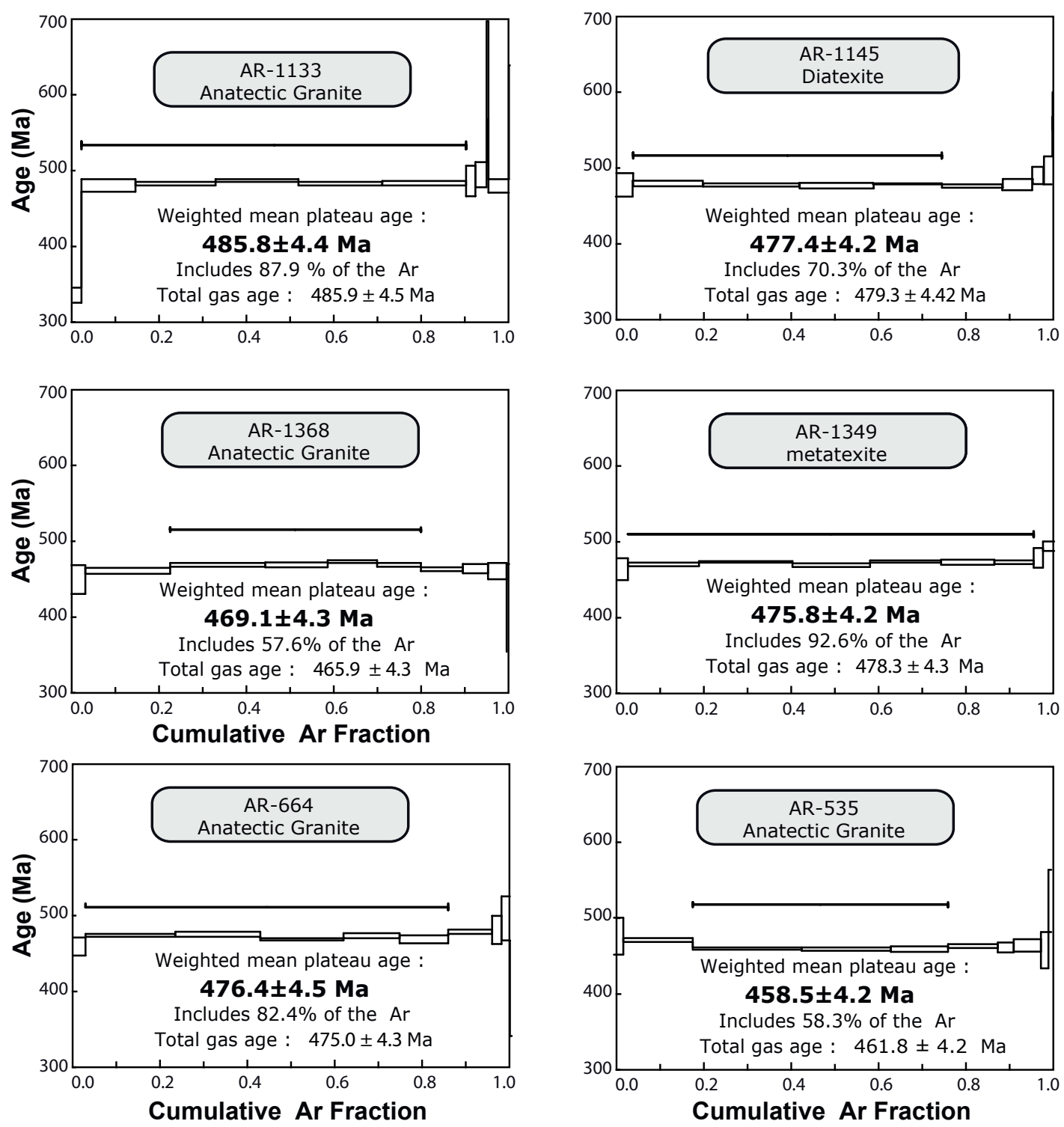

Figure 9: ${ }^{40} \mathrm{Ar} /{ }^{39} \mathrm{Ar}$ diagrams for biotite from samples collected in the Eastern Anatectic Unit. Diagrams are displayed for samples from North to South. Analytical data and methodology are available in supplementary data \#4 . 


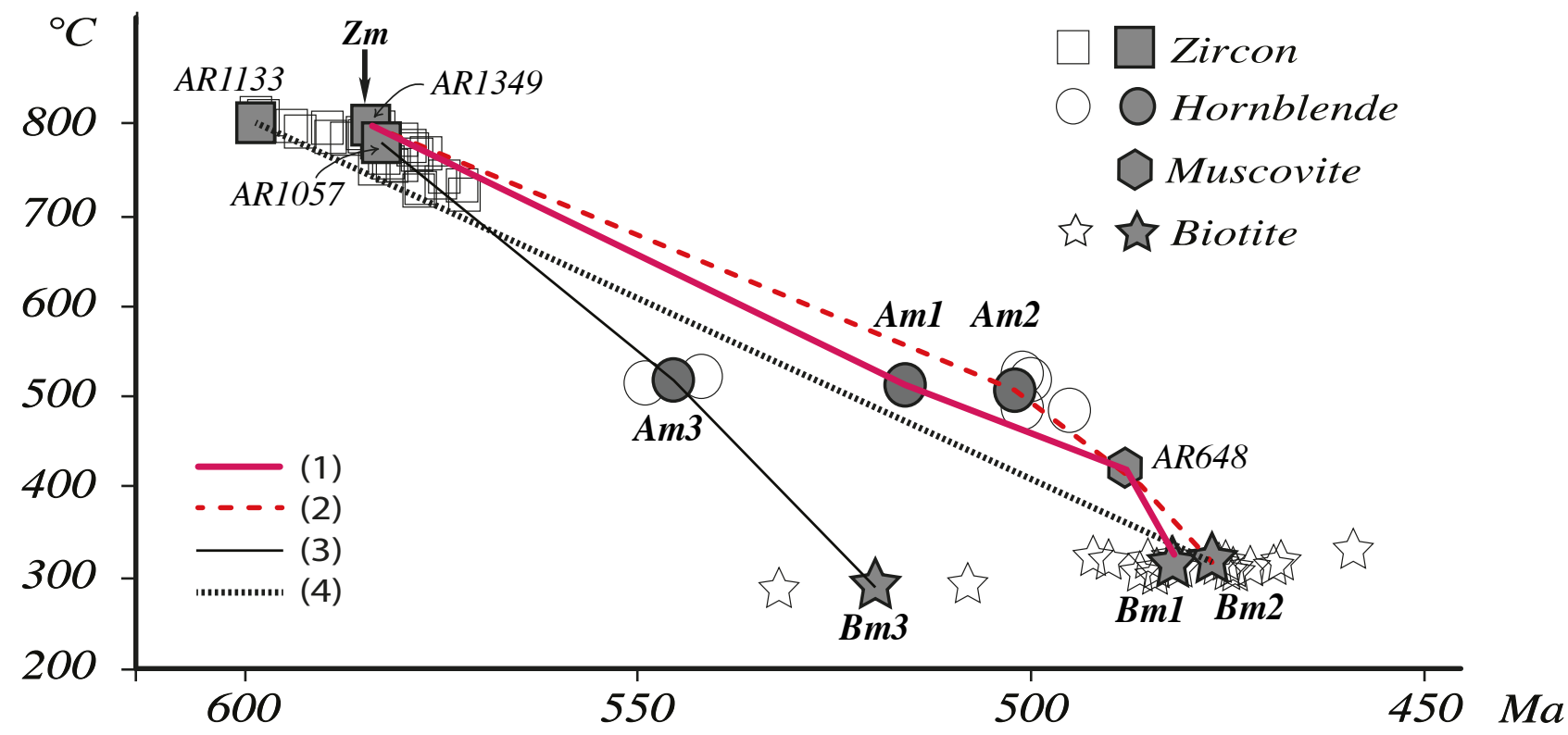

Figure 10: Figure 10: Diagram summarizing data and inferred thermochronological evolutions for the studied domain of the Araçuaí belt. Open symbols represents the whole set of data taken into account in this study. Symbols filled in grey represent either data for specific samples (zircons, muscovite) or average values computed for amphibole and biotite. Temperatures for zircons data have been roughly estimated from $(\mathrm{a})$ the peak temperature $\left(800^{\circ} \mathrm{C}\right)$ and the oldest age $(597 \mathrm{Ma})$ of the Eastern Anatectic Unit, (b) The $\mathrm{Zn}$-in rutile temperature $\left(780-790^{\circ} \mathrm{C}\right)$ obtained for sample AR-1349 (583 Ma), (c) equilibrium temperatures $\left(\sim 750^{\circ} \mathrm{C}\right)$ and ages (577-578 Ma) obtained for samples from the Western Mylonitic Unit, and (d) Ti-in-zircon temperature obtained for several samples from the EAU. $\mathrm{Zm}$ is average $\mathrm{U}-\mathrm{Pb}$ age of zircons from synkinematic magmatic/anatectic rocks, Am are average ${ }^{40} \mathrm{Ar} /{ }^{39} \mathrm{Ar}$ ages of amphiboles with $\mathrm{Am} 1$ for all dated samples and $\mathrm{Am} 2$ and $\mathrm{Am} 3$ without and for the two oldest samples, respectively. Similarly, $\mathrm{Bm}$ are average ${ }^{40} \mathrm{Ar} /{ }^{39} \mathrm{Ar}$ ages of biotites with $\mathrm{Bm} 1$ for all dated samples and $\mathrm{Bm} 2$ and $\mathrm{Bm} 3$ without and for the two oldest samples, respectively. Line (1) represents the thermochronological evolution based on average values for all dated samples, (2) excludes the two oldest amphiboles and biotites, (3) is the cooling evolution based on the mean ages of the two oldest amphiboles and biotites, and (4) links the oldest zircons ages of the Eastern Anatectic unit to average age of biotites. 


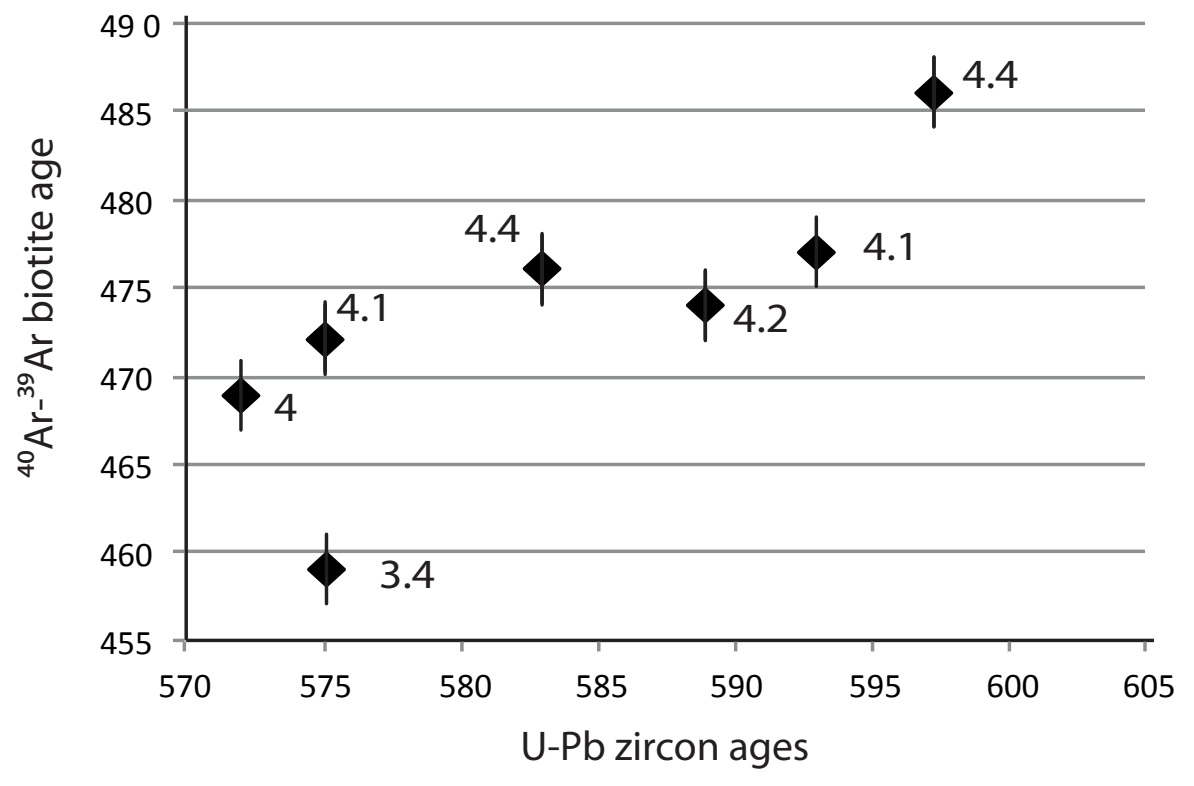

Figure 11: U-Pb zircon ages versus ${ }^{40} \mathrm{Ar} /{ }^{39} \mathrm{Ar}$ biotite ages in the Eastern Anatectic Unit. Numbers are for the cooling rate calculated for each sample (Table 1). This figure shows a tendency of the age of closure of the ${ }^{40} \mathrm{Ar} /{ }^{39} \mathrm{Ar}$ system in biotite to be correlated with zircon crystallization ages. Samples showing earlier crystallization of zircon also show earlier closure of the Ar/Ar system in biotite. This suggests a diachronous thermal evolution across the EAU. 

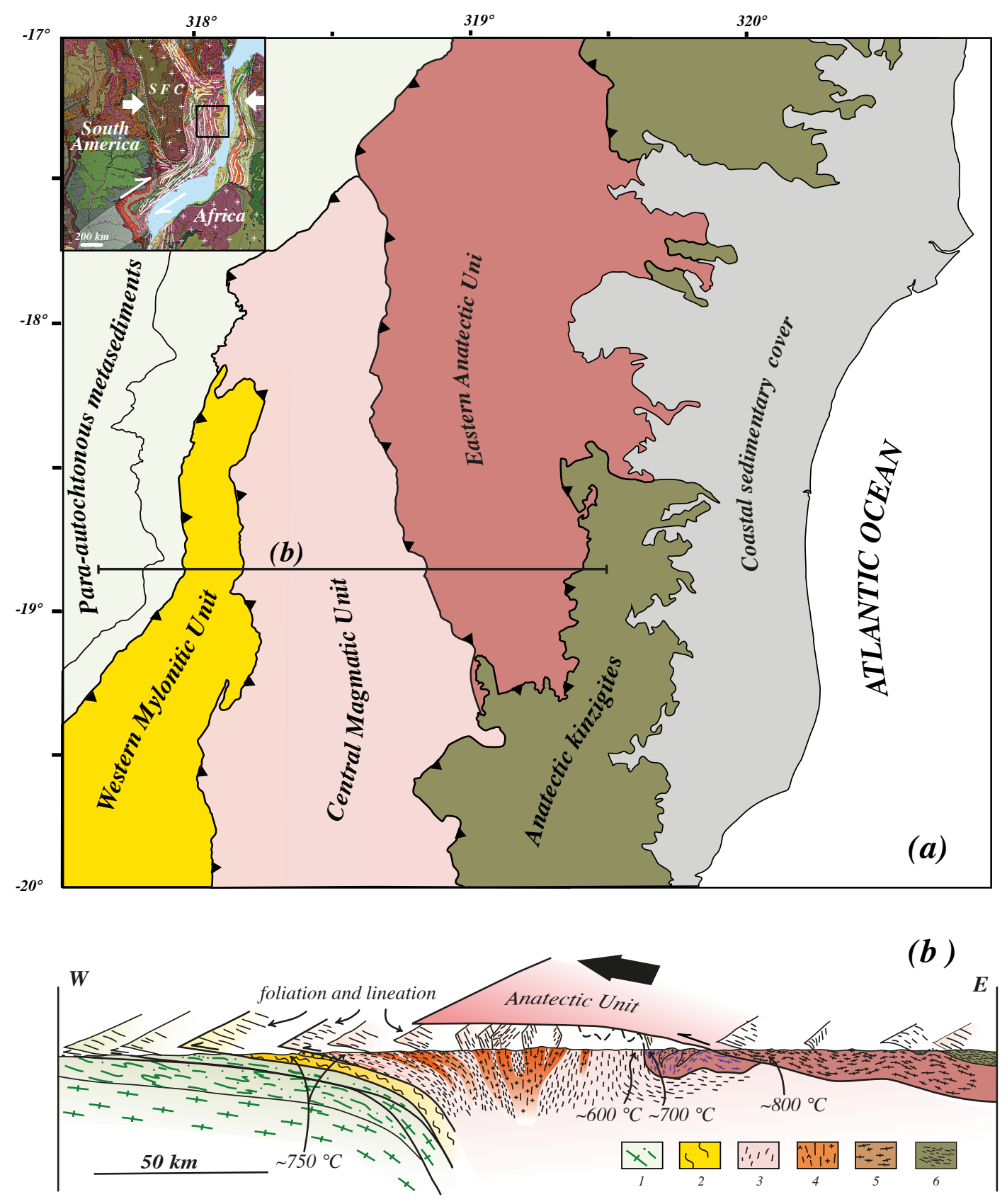

Figure 12: Schematic map and cross-section showing the Eastern Anatectic Unit thrust upon the Central and Western Units and even, in the northernmost part of the map, directly onto the paraautochthonous metasedimentary cover of the São Francisco craton. The cross-section also shows that the gently dipping basal contact of the Eastern unit crosscuts steeply dipping tectonic contacts and foliation in the eastern part of the CPU, suggesting that the tectonic emplacement of the EAU is later than the formation of this subvertical fabric, although it occurred before the anatexites reached solid-state. 


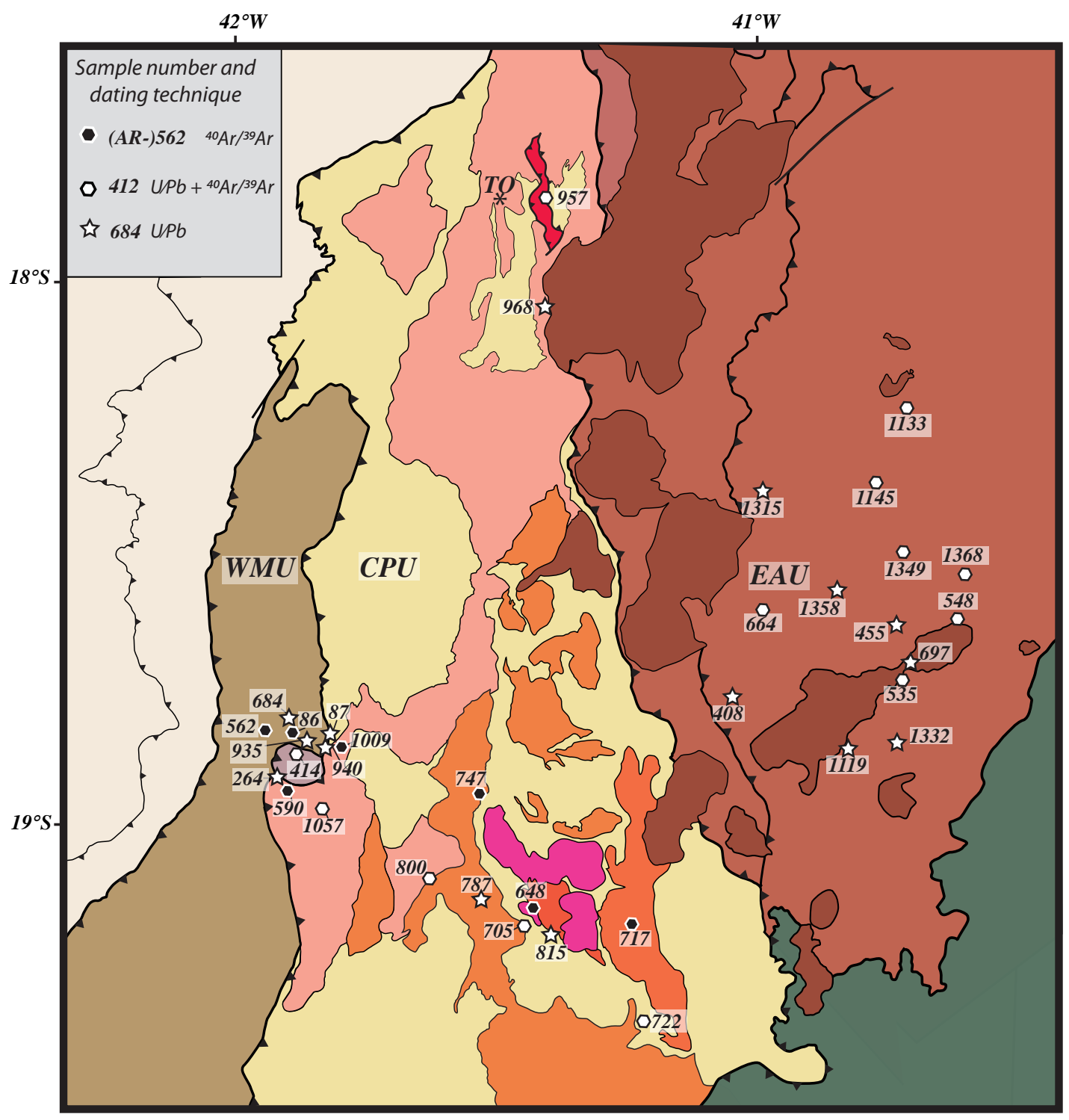

Supplementary material \#1: Location of samples from which zircons and/or amphibole, biotite and muscovite have been dated. Results (and references for data already published) are summarized in Table 1, Figure 4 for zircons and Figure 7 for ${ }^{40} \mathrm{Ar} /{ }^{39} \mathrm{Ar}$ ages. In the main text, sample numbers are preceded by AR- (for instance 562 is AR-562). Legends of the map as in Figure 2. 
Supplementary material \#2:

${ }^{40} \mathrm{Ar} /{ }^{39} \mathrm{Ar}$ data and diagram for sample AR-414 (Petitgirard et al., 2009).

Amphibole from this sample (Ibituruna syenite) did not yield a plateau age but a total gas age of $495.4 \pm 4.3 \mathrm{Ma}$ that should be considered as a minimum age for its closure for argon. Apparent ages slightly increase with increasing degassing temperatures up to apparent ages in the range 500-510 Ma corresponding to almost constant ${ }^{37} \mathrm{Ar} /{ }^{39} \mathrm{Ar}$ $(\mathrm{Ca} / \mathrm{K})$ and ${ }^{38} \mathrm{Ar} /{ }^{39} \mathrm{Ar}(\mathrm{Cl} / \mathrm{K})$ compositions. We thus preferred taking into account the integrated age of $505 \pm 5 \mathrm{Ma}$ for the amphibole from this sample.

\begin{tabular}{|c|c|c|c|c|c|c|c|c|c|}
\hline \multicolumn{4}{|c|}{ AR414 Ibituruna Syenite Amphibole } & \multicolumn{4}{|c|}{ Data from Petitgirard et al.. 2009} & \multirow[b]{2}{*}{ Age (Ma) } & \multirow[b]{2}{*}{$\begin{array}{c} \pm 1 \mathrm{SD} \\
\text { (Ma) }\end{array}$} \\
\hline Step & ${ }^{40} \mathrm{Ar} /{ }^{39} \mathrm{Ar}$ & ${ }^{38} \mathrm{Ar} /{ }^{39} \mathrm{Ar}$ & ${ }^{37} \mathrm{Ar} /{ }^{39} \mathrm{Ar}$ & $\begin{array}{c}{ }^{36} \mathrm{Ar} /{ }^{39} \mathrm{Ar} \\
\text { (E-3) }\end{array}$ & $\begin{array}{c}\mathbf{F}^{39} \mathrm{Ar} \\
\text { released }\end{array}$ & $\%^{40} \mathrm{Ar} *$ & ${ }^{40 * / 39} \mathrm{Ar}_{\mathrm{K}}$ & & \\
\hline 1 & 51.133 & 0.085 & 0.2841 & 133.399 & 0.99 & 22.90 & 11.71 & 186.1 & 2.2 \\
\hline 2 & 44.631 & 0.074 & 0.1807 & 93.225 & 1.49 & 38.26 & 17.08 & 265.4 & 2.2 \\
\hline 3 & 41.129 & 0.048 & 0.0574 & 30.448 & 3.08 & 78.08 & 32.12 & 470.5 & 0.6 \\
\hline 4 & 34.864 & 0.040 & 0.0072 & 3.000 & 15.41 & 97.40 & 33.96 & 494.1 & 0.2 \\
\hline 5 & 33.716 & 0.053 & 0.1632 & 0.863 & 30.92 & 99.21 & 33.45 & 487.6 & 0.3 \\
\hline 6 & 34.722 & 0.115 & 0.9239 & 1.309 & 54.47 & 98.99 & 34.39 & 499.6 & 0.4 \\
\hline 7 & 34.715 & 0.189 & 1.8392 & 0.875 & 77.15 & 99.52 & 34.59 & 502.1 & 0.2 \\
\hline 8 & 35.299 & 0.218 & 2.2291 & 1.184 & 91.93 & 99.33 & 35.11 & 508.7 & 0.2 \\
\hline 9 & 35.967 & 0.224 & 2.5280 & 3.007 & 94.47 & 97.90 & 35.27 & 510.7 & 0.4 \\
\hline 10 & 35.832 & 0.247 & 2.7335 & 2.467 & 98.33 & 98.37 & 35.31 & 511.2 & 0.3 \\
\hline 11 & 37.297 & 0.250 & 2.6180 & 13.641 & 98.63 & 89.56 & 33.46 & 487.7 & 1.7 \\
\hline 12 & 41.118 & 0.249 & 2.6689 & 22.207 & 100.00 & 84.38 & 34.76 & 504.3 & 1.1 \\
\hline
\end{tabular}

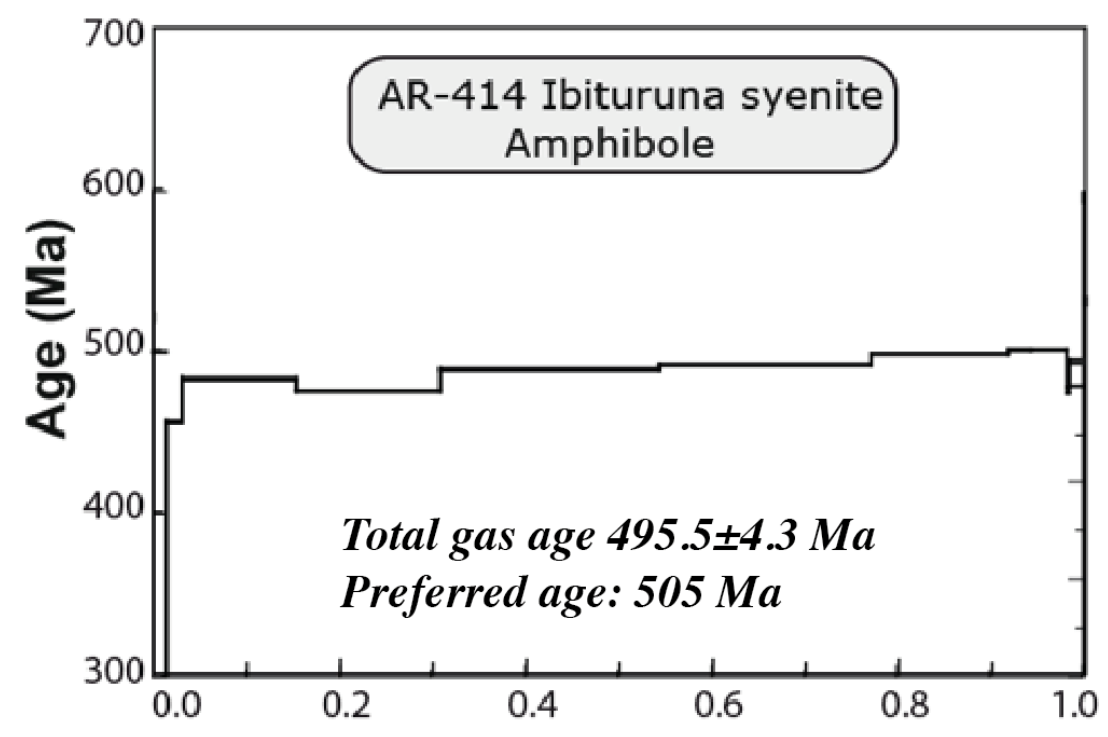

Petitgirard, S., Vauchez, A., Egydio-Silva, M., Bruguier, O., Camps, P., Monié, P., Babinski, M. and Mondou, M., 2009. Conflicting structural and geochronological data from the Ibituruna quartz-syenite (SE Brazil): Effect of protracted "hot" orogeny and slow cooling rate? Tectonophysics 477, 174-196. 
Supplementary material \#3:

\section{Ar-Ar results for samples from the Central Plutonic Unit}

\section{Method:}

These samples were collected for laser probe single grain ${ }^{40} \mathrm{Ar}^{39} \mathrm{Ar}$ studies at Geosciences Montpellier (Université de Montpellier, France). They were hand crushed and cleaned using ethanol and distilled water. Single grains of amphibole and mica about $500 \mu \mathrm{m}$ in diameter were handpicked under binocular microscope and ultrasonically cleaned in acetone and distilled water. The grains were then packaged in aluminium foils and irradiated along with several flux monitors of MMhb-1 hornblende and TCR2-sanidine at McMaster Reactor (Canada) with an integrated power of $60 \mathrm{MWH} . \mathrm{K}_{2} \mathrm{SO}_{4}$ and $\mathrm{CaF}_{2}$ salts were also irradiated to determine the correction factors for interference reactions from $\mathrm{K}$ and $\mathrm{Ca} .{ }^{40} \mathrm{Ar}-{ }^{39} \mathrm{Ar}$ laser degassing was carried out at Geosciences Montpellier (France) using a 50W CO 2 laser. The gas cleaning was achieved in a low volume UHV gas purification system including a cold trap and two Ti/Zr getters. Argon isotope measurements were performed on a MAP215-50 noble gas mass spectrometer directly connected to the UHV purification system. Blank analyses were performed every three runs to eliminate the background contribution on the gas released from the sample itself. Individual grains were stepwise heated by increasing the laser beam intensity in successive increments until the final fusion. A plateau age is defined by three or more contiguous heating steps comprising $50 \%$ or more of the ${ }^{39} \mathrm{Ar}_{\mathrm{K}}$ released and overlapping at the two-sigma confidence level. Because of the high radiogenic content of the dated minerals and the clustering of data points near the ${ }^{39} \mathrm{Ar}-{ }^{40} \mathrm{Ar}$ abscissa, ${ }^{36} \mathrm{Ar}-{ }^{40} \mathrm{Ar}$ versus ${ }^{39} \mathrm{Ar}-$ ${ }^{40} \mathrm{Ar}$ correlation plots do not provide meaningful information about the age and initial ${ }^{36} \mathrm{Ar}-{ }^{40} \mathrm{Ar}$ values.

\section{Results:}

\begin{tabular}{|c|c|c|c|c|c|c|c|c|c|}
\hline Step & ${ }^{40} \mathrm{Ar} /{ }^{39} \mathrm{Ar}$ & ${ }^{38} \mathrm{Ar} /{ }^{39} \mathrm{Ar}$ & ${ }^{37} \mathrm{Ar} /{ }^{39} \mathrm{Ar}$ & $\begin{array}{c}{ }^{36} \mathrm{Ar} /{ }^{39} \mathrm{Ar} \\
(\mathrm{E}-3)\end{array}$ & $\begin{array}{c}\mathbf{F}^{39} \mathrm{Ar} \\
\text { released }\end{array}$ & $\%^{40} \mathrm{Ar}^{*}$ & ${ }^{40 * / 39} \mathrm{Ar}_{\mathrm{K}}$ & Age (Ma) & $\begin{array}{c} \pm 1 \text { SD } \\
\text { (Ma) }\end{array}$ \\
\hline \multicolumn{10}{|c|}{ AR-590 Derribadinha tonalite Amphibole } \\
\hline 1 & 1190.597 & 0.088 & 0.00163 & 115.344 & 0.01 & 97.14 & 1156.5 & 4440.84 & 959.0 \\
\hline 2 & 525.881 & 0.414 & 37.06841 & 395.543 & 0.05 & 78.30 & 421.95 & 2871.623 & 139.9 \\
\hline 3 & 40.087 & 0.055 & 0.07051 & 11.151 & 12.52 & 91.75 & 36.78 & 529.416 & 2.8 \\
\hline 4 & 38.401 & 0.053 & 0.00000 & 3.618 & 16.75 & 97.17 & 37.32 & 536.056 & 3.8 \\
\hline 5 & 38.749 & 0.053 & 0.00000 & 3.893 & 23.39 & 96.99 & 37.58 & 539.361 & 2.4 \\
\hline 6 & 37.889 & 0.054 & 0.00000 & 1.733 & 36.33 & 98.61 & 37.36 & 536.607 & 1.5 \\
\hline 7 & 38.485 & 0.05 & 0.00000 & 2.784 & 39.29 & 97.82 & 37.65 & 540.157 & 2.3 \\
\hline 8 & 39.338 & 0.052 & 0.88118 & 4.345 & 41.82 & 96.86 & 38.13 & 546.099 & 2.4 \\
\hline 9 & 40.045 & 0.053 & 0.22236 & 5.34 & 45.71 & 96.06 & 38.47 & 550.377 & 3.4 \\
\hline 10 & 38.602 & 0.197 & 9.80187 & 4.637 & 58.67 & 98.32 & 38.2 & 546.953 & 1.8 \\
\hline 11 & 38.792 & 0.22 & 8.05135 & 4.118 & 66.52 & 98.38 & 38.36 & 549.036 & 2.3 \\
\hline 12 & 38.736 & 0.234 & 8.42765 & 3.584 & 89.15 & 98.86 & 38.5 & 550.762 & 1.2 \\
\hline 13 & 37.921 & 0.149 & 4.41234 & 3.567 & 92.30 & 98.05 & 37.29 & 535.727 & 3.7 \\
\hline
\end{tabular}




\begin{tabular}{|c|c|c|c|c|c|c|c|c|c|}
\hline 14 & 38.258 & 0.119 & 3.12708 & 2.99 & 100.00 & 98.26 & 37.67 & 540.452 & 2.3 \\
\hline \multicolumn{10}{|c|}{ AR-590 Derribadinha tonalite Biotite } \\
\hline 1 & 260.267 & 0.279 & 0.85808 & 821.286 & 0.12 & 6.77 & 17.64 & 273.22 & 249.9 \\
\hline 2 & 47.308 & 0.078 & 0.30582 & 47.638 & 0.99 & 70.26 & 33.24 & 484.733 & 8.4 \\
\hline 3 & 37.783 & 0.055 & 0.00454 & 4.487 & 9.95 & 96.45 & 36.44 & 525.151 & 1.9 \\
\hline 4 & 38.096 & 0.056 & 0.02386 & 5.614 & 14.51 & 95.61 & 36.42 & 524.927 & 2.4 \\
\hline 5 & 37.547 & 0.054 & 0.00000 & 1.838 & 23.02 & 98.51 & 36.99 & 531.976 & 1.9 \\
\hline 6 & 36.978 & 0.051 & 0.00894 & 0.905 & 30.26 & 99.24 & 36.70 & 528.325 & 2.8 \\
\hline 7 & 37.316 & 0.052 & 0.00000 & 1.352 & 39.65 & 98.89 & 36.90 & 530.883 & 1.5 \\
\hline 8 & 37.577 & 0.052 & 0.02104 & 1.507 & 44.11 & 98.78 & 37.12 & 533.591 & 2.0 \\
\hline 9 & 37.213 & 0.052 & 0.00000 & 1.592 & 50.89 & 98.69 & 36.73 & 528.715 & 2.5 \\
\hline 10 & 37.553 & 0.053 & 0.01094 & 1.671 & 54.61 & 98.65 & 37.04 & 532.675 & 2.6 \\
\hline 11 & 37.395 & 0.054 & 0.00957 & 1.835 & 58.77 & 98.51 & 36.84 & 530.104 & 2.1 \\
\hline 12 & 37.339 & 0.054 & 0.00419 & 1.298 & 71.42 & 98.93 & 36.94 & 531.374 & 1.7 \\
\hline 13 & 38.200 & 0.054 & 0.02762 & 2.665 & 77.27 & 97.90 & 37.40 & 537.086 & 2.2 \\
\hline 14 & 37.479 & 0.053 & 0.00051 & 1.614 & 82.08 & 98.69 & 36.99 & 531.947 & 1.5 \\
\hline 15 & 37.740 & 0.053 & 0.00000 & 1.817 & 87.03 & 98.54 & 37.19 & 534.458 & 2.2 \\
\hline 16 & 37.682 & 0.054 & 0.01606 & 1.812 & 93.55 & 98.54 & 37.13 & 533.775 & 1.7 \\
\hline 17 & 37.827 & 0.052 & 0.00000 & 2.458 & 100.00 & 98.04 & 37.09 & 533.182 & 2.3 \\
\hline \multicolumn{4}{|c|}{ AR-1057 São Vitor tonalite Amphibole } & $=0.009621$ & & & & & \\
\hline 1 & 1318.154 & 5.167 & 0.01591 & 4055.33 & 0.01 & 9.09 & 119.79 & 1383.1 & 7131.5 \\
\hline 2 & 137.46 & 1.089 & 0.00341 & 248.554 & 0.06 & 46.56 & 64 & 865.6 & 1790.6 \\
\hline 3 & 87.653 & 1.146 & 0.00438 & 857.07 & 0.10 & -188.96 & -165.63 & 0.0 & 0.0 \\
\hline 4 & 73.132 & 0.824 & 0.00216 & 49.913 & 0.19 & 79.81 & 58.37 & 804.0 & 1148.4 \\
\hline 5 & 26.992 & 0.121 & 0.00062 & 0.002 & 0.47 & 99.94 & 26.98 & 416.3 & 14.2 \\
\hline 6 & 33.716 & 0.136 & 0.00121 & 0.003 & 0.62 & 99.95 & 33.7 & 506.6 & 23.1 \\
\hline 7 & 33.403 & 0 & 0.00064 & 0.002 & 0.90 & 99.95 & 33.39 & 502.5 & 11.7 \\
\hline 8 & 36.065 & 0.038 & 0.00015 & 0 & 2.13 & 99.96 & 36.05 & 537.2 & 6.9 \\
\hline 9 & 36.223 & 0.103 & 0.00001 & 0 & 24.26 & 99.96 & 36.21 & 539.2 & 8.1 \\
\hline 10 & 36.476 & 0.083 & 0.00003 & 0 & 29.92 & 99.96 & 36.46 & 542.5 & 4.1 \\
\hline 11 & 36.61 & 0.11 & 0.00000 & 0 & 67.39 & 99.96 & 36.59 & 544.2 & 7.7 \\
\hline 12 & 36.231 & 0.073 & 0.00003 & 0 & 74.18 & 99.96 & 36.22 & 539.3 & 10.1 \\
\hline 13 & 36.788 & 0.053 & 0.00014 & 0 & 75.42 & 99.96 & 36.77 & 546.5 & 8.0 \\
\hline 14 & 36.393 & 0.09 & 0.00003 & 0 & 82.57 & 99.96 & 36.38 & 541.4 & 2.8 \\
\hline 15 & 36.267 & 0.055 & 0.00001 & 0 & 100.00 & 99.96 & 36.25 & 539.8 & 6.7 \\
\hline \multicolumn{4}{|c|}{ AR-1057 São Vitor tonalite Biotite } & \multicolumn{6}{|c|}{$\mathrm{J}=0.009621$} \\
\hline 1 & 110.008 & 0.856 & 51.77421 & 633.621 & 0.02 & -66.68 & -75.92 & 0.0 & 0.0 \\
\hline 2 & 55.347 & 0.118 & 42.76951 & 156.805 & 0.05 & 22.05 & 12.55 & 205.7 & 635.9 \\
\hline 3 & 19.962 & 0 & 27.29096 & 4.961 & 0.12 & 99.92 & 20.9 & 330.5 & 253.3 \\
\hline 4 & 30.371 & 0.041 & 1.20390 & 11.343 & 0.44 & 89.21 & 27.12 & 418.2 & 54.5 \\
\hline 5 & 32.03 & 0.03 & 0.00003 & 2.986 & 1.30 & 97.2 & 31.13 & 472.7 & 20.0 \\
\hline 6 & 34.103 & 0.024 & 5.91843 & 19.592 & 2.40 & 84.28 & 28.85 & 442.0 & 16.0 \\
\hline 7 & 33.375 & 0.021 & 0.00001 & 0 & 5.04 & 99.95 & 33.36 & 502.2 & 4.0 \\
\hline 8 & 33.621 & 0.021 & 0.00001 & 0 & 7.65 & 99.95 & 33.61 & 505.4 & 2.4 \\
\hline 9 & 33.872 & 0.022 & 0.00001 & 0.173 & 10.01 & 99.8 & 33.81 & 508.0 & 8.0 \\
\hline 10 & 33.672 & 0.019 & 0.00001 & 0 & 14.42 & 99.95 & 33.66 & 506.1 & 2.1 \\
\hline 11 & 33.639 & 0.017 & 0.00001 & 0 & 18.01 & 99.95 & 33.62 & 505.6 & 4.1 \\
\hline 12 & 33.621 & 0.013 & 0.00001 & 0 & 20.48 & 99.95 & 33.61 & 505.4 & 4.8 \\
\hline 13 & 33.401 & 0.025 & 0.68492 & 0 & 25.61 & 99.95 & 33.45 & 503.4 & 3.8 \\
\hline 14 & 33.81 & 0.019 & 0.00001 & 0 & 29.71 & 99.95 & 33.79 & 507.9 & 2.6 \\
\hline
\end{tabular}




\begin{tabular}{|c|c|c|c|c|c|c|c|c|c|}
\hline 15 & 33.405 & 0.016 & 0.15295 & 0 & 33.97 & 99.95 & 33.4 & 502.8 & 3.5 \\
\hline 16 & 33.596 & 0.018 & 0.00995 & 0 & 36.51 & 99.95 & 33.58 & 505.1 & 1.9 \\
\hline 17 & 33.77 & 0.019 & 0.47576 & 0 & 39.37 & 99.95 & 33.8 & 508.0 & 1.9 \\
\hline 18 & 33.827 & 0.028 & 0.09567 & 0 & 48.56 & 99.95 & 33.82 & 508.2 & 5.0 \\
\hline 19 & 33.52 & 0.018 & 0.00001 & 0 & 53.17 & 99.95 & 33.5 & 504.1 & 3.1 \\
\hline 20 & 33.961 & 0.019 & 0.00000 & 0 & 61.48 & 99.95 & 33.95 & 509.9 & 2.6 \\
\hline 21 & 33.56 & 0.021 & 0.00001 & 0.725 & 64.49 & 99.32 & 33.33 & 501.8 & 5.9 \\
\hline 22 & 33.94 & 0.021 & 0.00001 & 0 & 68.98 & 99.95 & 33.92 & 509.6 & 2.6 \\
\hline 23 & 33.895 & 0.019 & 0.00001 & 0 & 72.19 & 99.95 & 33.88 & 509.0 & 4.8 \\
\hline 24 & 33.485 & 0.021 & 0.39021 & 0 & 78.31 & 99.95 & 33.51 & 504.1 & 8.5 \\
\hline 25 & 33.807 & 0.018 & 0.03891 & 0.776 & 81.48 & 99.28 & 33.57 & 504.9 & 6.2 \\
\hline 26 & 33.809 & 0.02 & 0.11646 & 0.905 & 85.65 & 99.19 & 33.54 & 504.5 & 4.8 \\
\hline 27 & 33.911 & 0.02 & 0.00000 & 0 & 92.58 & 99.95 & 33.9 & 509.2 & 1.4 \\
\hline 28 & 33.821 & 0.019 & 0.00001 & 0 & 94.72 & 99.95 & 33.81 & 508.0 & 3.3 \\
\hline 29 & 33.943 & 0.02 & 0.00001 & 0.354 & 98.05 & 99.65 & 33.82 & 508.2 & 5.8 \\
\hline 30 & 33.419 & 0.023 & 0.00001 & 0 & 100.00 & 99.95 & 33.4 & 502.8 & 1.4 \\
\hline \multicolumn{4}{|c|}{ AR-1009 São Vitor tonalite Amphibole } & $\mathrm{J}=0.009621$ & & & & & \\
\hline 1 & 240.903 & 2.011 & 0.00999 & 0.029 & 0.02 & 99.99 & 240.88 & 2163.5 & 187.3 \\
\hline 2 & 110.055 & 0 & 0.00470 & 0.014 & 0.07 & 99.98 & 110.04 & 1302.6 & 104.3 \\
\hline 3 & 31.356 & 0.142 & 0.00148 & 0.004 & 0.21 & 99.95 & 31.34 & 475.4 & 36.4 \\
\hline 4 & 26.766 & 0 & 0.00195 & 0.006 & 0.31 & 99.94 & 26.75 & 413.1 & 43.5 \\
\hline 5 & 13.629 & 0.094 & 0.00048 & 0.001 & 0.75 & 99.88 & 13.61 & 222.0 & 12.5 \\
\hline 6 & 32.837 & 0.098 & 0.00007 & 0 & 3.84 & 99.95 & 32.82 & 495.1 & 5.7 \\
\hline 7 & 32.942 & 0.092 & 0.00001 & 0 & 30.41 & 99.95 & 32.93 & 496.5 & 21.6 \\
\hline 8 & 33.752 & 0.116 & 0.00001 & 0 & 56.55 & 99.95 & 33.74 & 507.1 & 10.3 \\
\hline 9 & 33.243 & 0.104 & 0.00002 & 0 & 69.92 & 99.95 & 33.23 & 500.4 & 4.6 \\
\hline 10 & 33.177 & 0.094 & 0.00001 & 0 & 89.86 & 99.95 & 33.16 & 499.6 & 7.7 \\
\hline 11 & 36.04 & 0.126 & 0.00008 & 8.32 & 92.38 & 93.13 & 33.57 & 504.9 & 54.6 \\
\hline 12 & 35.724 & 0.111 & 0.00749 & 9.601 & 100.00 & 92.02 & 32.87 & 495.7 & 19.3 \\
\hline \multicolumn{4}{|c|}{ AR-1009 São Vitor tonalite Biotite } & $\mathrm{J}=0.009621$ & & & & & \\
\hline 1 & 17.141 & 0.063 & 0.00031 & 48.478 & 0.21 & 16.34 & 2.8 & 48.0 & 246.5 \\
\hline 2 & 19.604 & 0.054 & 2.54802 & 27.182 & 0.64 & 59.92 & 11.77 & 193.5 & 112.0 \\
\hline 3 & 30.648 & 0.027 & 0.23931 & 2.129 & 12.46 & 97.96 & 30.03 & 457.8 & 4.8 \\
\hline 4 & 33.241 & 0.033 & 0.56846 & 3.592 & 21.69 & 96.89 & 32.22 & 487.1 & 5.9 \\
\hline 5 & 32.232 & 0.025 & 0.00002 & 0 & 26.50 & 99.95 & 32.22 & 487.1 & 2.4 \\
\hline 6 & 32.84 & 0.028 & 0.48662 & 3.662 & 34.88 & 96.77 & 31.79 & 481.4 & 6.6 \\
\hline 7 & 32.752 & 0.028 & 0.70427 & 3.193 & 43.07 & 97.23 & 31.86 & 482.4 & 6.6 \\
\hline 8 & 32.715 & 0.028 & 0.20325 & 0.356 & 64.36 & 99.68 & 32.61 & 492.3 & 3.6 \\
\hline 9 & 32.546 & 0.023 & 0.00001 & 0 & 69.86 & 99.95 & 32.53 & 491.2 & 1.3 \\
\hline 10 & 32.668 & 0.024 & 0.08151 & 0.609 & 82.04 & 99.42 & 32.48 & 490.6 & 4.4 \\
\hline 11 & 32.741 & 0.018 & 1.23529 & 1.025 & 84.66 & 99.31 & 32.54 & 491.4 & 20.1 \\
\hline 12 & 32.509 & 0.025 & 0.40070 & 1.045 & 100.00 & 99.09 & 32.22 & 487.2 & 2.5 \\
\hline \multicolumn{4}{|c|}{ AR-800 São Vitor tonalite Biotite } & \multicolumn{6}{|l|}{$\mathrm{J}=0.009621$} \\
\hline 1 & 24.463 & 0.038 & 0.00042 & 0.001 & 0.24 & 99.93 & 24.45 & 381.1 & 11.0 \\
\hline 2 & 27.11 & 0 & 0.00006 & 0 & 1.91 & 99.94 & 27.09 & 417.9 & 2.6 \\
\hline 3 & 31.993 & 0.013 & 0.00000 & 0 & 24.01 & 99.95 & 31.98 & 483.9 & 3.2 \\
\hline 4 & 32.104 & 0.01 & 0.03448 & 0 & 40.98 & 99.95 & 32.09 & 485.4 & 1.0 \\
\hline 5 & 31.991 & 0.01 & 0.32973 & 0.101 & 65.29 & 99.94 & 31.98 & 483.9 & 2.8 \\
\hline 6 & 31.174 & 0.01 & 1.67359 & 0.53 & 73.66 & 99.85 & 31.16 & 473.1 & 7.9 \\
\hline 7 & 32.499 & 0.014 & 0.30455 & 1.315 & 87.06 & 98.83 & 32.12 & 485.9 & 4.3 \\
\hline 8 & 31.573 & 0.015 & 0.92221 & 1.489 & 91.94 & 98.78 & 31.21 & 473.6 & 11.6 \\
\hline 9 & 31.366 & 0.014 & 2.65175 & 0 & 96.19 & 99.95 & 31.6 & 479.0 & 2.1 \\
\hline 10 & 29.342 & 0.012 & 5.49134 & 0 & 97.99 & 99.95 & 29.85 & 455.4 & 4.7 \\
\hline
\end{tabular}




\begin{tabular}{|c|c|c|c|c|c|c|c|c|c|}
\hline 11 & 29.15 & 0.004 & 5.97273 & 0 & 100.00 & 99.95 & 29.7 & 453.4 & 2.3 \\
\hline \multicolumn{4}{|c|}{ AR-705 Galiléia tonalite Biotite } & \multicolumn{6}{|l|}{$\mathrm{J}=0.009143$} \\
\hline 1 & 47.49 & 0.035 & 0.09484 & 69.249 & 0.96 & 56.89 & 27.02 & 398.3 & 9.4 \\
\hline 2 & 34.542 & 0.019 & 0.04145 & 5.079 & 7.90 & 95.62 & 33.03 & 476.1 & 1.7 \\
\hline 3 & 34.124 & 0.019 & 0.03185 & 3.779 & 13.88 & 96.69 & 32.99 & 475.6 & 2.0 \\
\hline 4 & 34.076 & 0.018 & 0.02898 & 4.019 & 17.51 & 96.48 & 32.88 & 474.1 & 2.4 \\
\hline 5 & 35.064 & 0.017 & 0.00153 & 7.771 & 26.51 & 93.41 & 32.75 & 472.6 & 1.3 \\
\hline 6 & 33.221 & 0.017 & 0.00252 & 1.093 & 61.59 & 98.98 & 32.88 & 474.2 & 1.1 \\
\hline 7 & 33.451 & 0.016 & 0.00933 & 1.446 & 78.28 & 98.68 & 33.01 & 475.8 & 1.7 \\
\hline 8 & 33.74 & 0.015 & 0.00433 & 2.203 & 84.24 & 98.03 & 33.07 & 476.6 & 1.8 \\
\hline 9 & 33.62 & 0.015 & 0.04585 & 1.566 & 89.05 & 98.59 & 33.15 & 477.6 & 3.5 \\
\hline 10 & 33.468 & 0.019 & 0.00000 & 3.643 & 90.78 & 96.74 & 32.38 & 467.8 & 3.9 \\
\hline 11 & 33.088 & 0.016 & 0.00000 & 3.046 & 95.39 & 97.23 & 32.17 & 465.2 & 2.4 \\
\hline 12 & 33.857 & 0.021 & 0.01916 & 3.274 & 97.83 & 97.1 & 32.88 & 474.1 & 2.7 \\
\hline 13 & 34.062 & 0.022 & 0.30465 & 1.224 & 100.00 & 98.96 & 33.71 & 484.7 & 3.7 \\
\hline \multicolumn{4}{|c|}{ AR-957 Galiléia tonalite Biotite } & \multicolumn{6}{|l|}{$\mathrm{J}=0.009621$} \\
\hline 1 & 90.921 & 0.123 & 0.00007 & 220.372 & 0.47 & 28.36 & 25.79 & 399.8 & 45.0 \\
\hline 2 & 28.051 & 0.133 & 0.00002 & 38.963 & 1.93 & 58.9 & 16.52 & 266.1 & 16.0 \\
\hline 3 & 26.711 & 0.083 & 0.00001 & 0 & 5.44 & 99.94 & 26.7 & 412.4 & 11.3 \\
\hline 4 & 31.753 & 0.099 & 0.00000 & 0 & 13.66 & 99.95 & 31.74 & 480.7 & 10.7 \\
\hline 5 & 32.575 & 0.081 & 0.00001 & 0 & 19.06 & 99.95 & 32.56 & 491.6 & 4.1 \\
\hline 6 & 31.829 & 0.095 & 0.00000 & 0 & 32.63 & 99.95 & 31.81 & 481.7 & 8.0 \\
\hline 7 & 32.456 & 0.095 & 0.00000 & 0 & 41.55 & 99.95 & 32.44 & 490.1 & 2.4 \\
\hline 8 & 32.39 & 0.087 & 0.74200 & 0.619 & 46.68 & 99.56 & 32.26 & 487.7 & 6.4 \\
\hline 9 & 32.439 & 0.088 & 2.72211 & 0 & 51.05 & 99.95 & 32.69 & 493.3 & 6.8 \\
\hline 10 & 32.654 & 0.063 & 0.00000 & 0 & 58.09 & 99.95 & 32.64 & 492.7 & 4.2 \\
\hline 11 & 32.703 & 0.104 & 0.19190 & 0 & 61.17 & 99.95 & 32.71 & 493.6 & 1.7 \\
\hline 12 & 32.701 & 0.069 & 0.00000 & 0 & 71.31 & 99.95 & 32.69 & 493.3 & 2.6 \\
\hline 13 & 32.35 & 0.1 & 0.00001 & 0 & 77.13 & 99.95 & 32.33 & 488.7 & 4.4 \\
\hline 14 & 32.634 & 0.087 & 1.00316 & 0.444 & 79.83 & 99.78 & 32.58 & 491.9 & 8.7 \\
\hline 15 & 32.839 & 0.062 & 0.00003 & 0 & 80.90 & 99.95 & 32.82 & 495.1 & 1.0 \\
\hline 16 & 31.988 & 0.12 & 0.18118 & 0 & 100.00 & 99.95 & 31.99 & 484.1 & 1.0 \\
\hline \multicolumn{4}{|c|}{ AR-747 Galiléia tonalite Biotite } & \multicolumn{6}{|l|}{$\mathrm{J}=0.009143$} \\
\hline 1 & 57.422 & 0.03 & 0.01364 & 91.03 & 1.61 & 53.13 & 30.51 & 443.9 & 7.1 \\
\hline 2 & 39.955 & 0.022 & 0.02162 & 25.911 & 4.52 & 80.8 & 32.28 & 466.6 & 2.8 \\
\hline 3 & 35.88 & 0.016 & 0.00738 & 9.687 & 9.02 & 91.98 & 33 & 475.7 & 3.3 \\
\hline 4 & 34.273 & 0.015 & 0.00168 & 2.766 & 20.32 & 97.57 & 33.44 & 481.3 & 0.9 \\
\hline 5 & 34.296 & 0.015 & 0.00014 & 2.832 & 31.62 & 97.51 & 33.44 & 481.3 & 1.1 \\
\hline 6 & 33.764 & 0.015 & 0.01223 & 0.697 & 40.13 & 99.35 & 33.54 & 482.6 & 2.4 \\
\hline 7 & 33.859 & 0.015 & 0.00433 & 1.196 & 56.64 & 98.91 & 33.49 & 481.9 & 1.1 \\
\hline 8 & 33.859 & 0.015 & 0.00036 & 1.196 & 73.15 & 98.91 & 33.49 & 481.9 & 1.1 \\
\hline 9 & 34.115 & 0.015 & 0.00573 & 1.423 & 81.64 & 98.72 & 33.68 & 484.3 & 2.2 \\
\hline 10 & 34.308 & 0.015 & 0.00025 & 2.258 & 84.00 & 98.01 & 33.63 & 483.6 & 1.9 \\
\hline 11 & 33.948 & 0.016 & 0.00000 & 1.262 & 86.30 & 98.86 & 33.56 & 482.8 & 2.7 \\
\hline 12 & 34.072 & 0.016 & 0.00000 & 2.071 & 89.38 & 98.16 & 33.44 & 481.3 & 1.2 \\
\hline 13 & 34.353 & 0.016 & 0.00000 & 2.806 & 90.79 & 97.54 & 33.51 & 482.1 & 1.5 \\
\hline 14 & 33.582 & 0.014 & 0.01767 & 1.878 & 91.79 & 98.31 & 33.01 & 475.9 & 2.1 \\
\hline 15 & 33.964 & 0.016 & 0.09576 & 2.674 & 93.24 & 97.65 & 33.17 & 477.8 & 2.6 \\
\hline 16 & 34.171 & 0.015 & 0.04058 & 2.497 & 95.25 & 97.8 & 33.42 & 481.0 & 1.7 \\
\hline 17 & 34.185 & 0.013 & 0.03524 & 2.226 & 95.88 & 98.04 & 33.51 & 482.2 & 2.4 \\
\hline 18 & 35.065 & 0.012 & 0.04808 & 3.948 & 96.45 & 96.64 & 33.89 & 486.9 & 2.7 \\
\hline 19 & 34.571 & 0.016 & 0.37912 & 3.552 & 100.00 & 97 & 33.54 & 482.6 & 2.1 \\
\hline
\end{tabular}




\begin{tabular}{|c|c|c|c|c|c|c|c|c|c|}
\hline \multicolumn{4}{|c|}{ AR-722 Orthogneiss Biotite } & \multicolumn{6}{|l|}{$\mathrm{J}=0.009143$} \\
\hline 1 & 159.363 & 0.099 & 0.00000 & 464.193 & 1.87 & 13.92 & 22.18 & 333.1 & 21.7 \\
\hline 2 & 34.741 & 0.014 & 0.00000 & 6.242 & 14.58 & 94.65 & 32.88 & 474.2 & 2.6 \\
\hline 3 & 34.216 & 0.014 & 0.00000 & 1.643 & 47.17 & 98.54 & 33.72 & 484.7 & 3.5 \\
\hline 4 & 33.938 & 0.014 & 0.01015 & 0.977 & 60.65 & 99.11 & 33.63 & 483.7 & 1.7 \\
\hline 5 & 33.969 & 0.014 & 0.01127 & 0.317 & 68.16 & 99.68 & 33.86 & 486.6 & 8.2 \\
\hline 6 & 34.18 & 0.013 & 0.00113 & 1.167 & 73.52 & 98.95 & 33.82 & 486.1 & 3.3 \\
\hline 7 & 33.726 & 0.016 & 0.00313 & 0.389 & 79.06 & 99.61 & 33.6 & 483.3 & 3.3 \\
\hline 8 & 33.956 & 0.014 & 0.00000 & 0.523 & 82.42 & 99.5 & 33.79 & 485.6 & 3.1 \\
\hline 9 & 34.568 & 0.015 & 0.04584 & 1.497 & 85.25 & 98.68 & 34.11 & 489.8 & 3.2 \\
\hline 10 & 34.858 & 0.01 & 0.04797 & 4.659 & 87.71 & 96.02 & 33.47 & 481.7 & 3.2 \\
\hline 11 & 34.272 & 0.016 & 0.00315 & 2.179 & 90.25 & 98.08 & 33.61 & 483.5 & 2.2 \\
\hline 12 & 34.487 & 0.01 & 0.00000 & 2.001 & 92.79 & 98.24 & 33.88 & 486.8 & 3.1 \\
\hline 13 & 34.305 & 0.008 & 0.04174 & 1.852 & 93.90 & 98.37 & 33.75 & 485.1 & 3.2 \\
\hline 14 & 33.628 & 0.013 & 0.00000 & 0 & 95.50 & 99.95 & 33.61 & 483.5 & 3.4 \\
\hline 15 & 35.277 & 0.016 & 0.00000 & 5.575 & 96.17 & 95.29 & 33.61 & 483.5 & 3.1 \\
\hline 16 & 33.888 & 0.015 & 0.00000 & 0.891 & 100.00 & .18 & 33.61 & 483.4 & 2.4 \\
\hline \multicolumn{4}{|c|}{ AR-717 Galiléia tonalite Amphibole } & \multicolumn{6}{|l|}{$\mathrm{J}=0.009143$} \\
\hline 1 & 34.57 & 0.087 & 2.81088 & 1.655 & 9.34 & 99.15 & 34.34 & 492.6 & 1.7 \\
\hline 2 & 35.003 & 0.1 & 3.03178 & 0.741 & 43.23 & 99.96 & 35.07 & 501.7 & 1.0 \\
\hline 3 & 36.44 & 0.098 & 2.87131 & 5.795 & 46.51 & 95.85 & 34.99 & 500.8 & 1.9 \\
\hline 4 & 34.743 & 0.099 & 3.01849 & 0.501 & 71.53 & 99.96 & 34.87 & 499.3 & 0.8 \\
\hline 5 & 35.207 & 0.097 & 3.19382 & 1.54 & 74.55 & 99.34 & 35.05 & 501.5 & 3.4 \\
\hline 6 & 34.857 & 0.094 & 3.17437 & 0.909 & 77.87 & 99.87 & 34.88 & 499.4 & 3.6 \\
\hline 7 & 33.844 & 0.093 & 3.06684 & 1.285 & 81.76 & 99.51 & 33.75 & 485.1 & 1.4 \\
\hline 8 & 34.243 & 0.096 & 3.08908 & 1.2 & 84.98 & 99.6 & 34.17 & 490.5 & 2.8 \\
\hline 9 & 34.695 & 0.089 & 3.04323 & 0 & 86.34 & 99.96 & 34.98 & 500.6 & 2.8 \\
\hline 10 & 34.46 & 0.087 & 3.50846 & 0 & 87.96 & 99.95 & 34.79 & 498.2 & 2.2 \\
\hline 11 & 34.269 & 0.101 & 4.06140 & 0.423 & 89.99 & 99.95 & 34.52 & 494.9 & 3.4 \\
\hline 12 & 34.294 & 0.086 & 4.88181 & 1.663 & 100.00 & 99.59 & 34.26 & 491.6 & 1.8 \\
\hline \multicolumn{4}{|c|}{ AR-717 Galiléia tonalite Biotite } & \multicolumn{6}{|l|}{$\mathrm{J}=0.009143$} \\
\hline 1 & 69.019 & 0.051 & 0.01228 & 123.733 & 3.52 & 47 & 32.44 & 468.6 & 4.8 \\
\hline 2 & 41.894 & 0.034 & 0.00000 & 32.376 & 5.10 & 77.13 & 32.31 & 467.0 & 4.2 \\
\hline 3 & 39.081 & 0.029 & 0.00000 & 20.501 & 10.99 & 84.46 & 33.01 & 475.8 & 1.4 \\
\hline 4 & 37.388 & 0.03 & 0.00000 & 13.371 & 16.72 & 89.39 & 33.42 & 481.0 & 1.4 \\
\hline 5 & 36.138 & 0.028 & 0.00294 & 9.623 & 22.38 & 92.09 & 33.28 & 479.2 & 1.3 \\
\hline 6 & 36.239 & 0.027 & 0.00000 & 9.562 & 26.30 & 92.16 & 33.4 & 480.7 & 3.0 \\
\hline 7 & 35.741 & 0.027 & 0.01162 & 8.044 & 30.38 & 93.31 & 33.35 & 480.1 & 1.3 \\
\hline 8 & 34.784 & 0.027 & 0.00000 & 4.364 & 40.46 & 96.25 & 33.48 & 481.8 & 1.8 \\
\hline 9 & 34.724 & 0.026 & 0.00451 & 4.722 & 46.91 & 95.94 & 33.31 & 479.7 & 2.1 \\
\hline 10 & 34.831 & 0.024 & 0.00000 & 4.944 & 51.38 & 95.76 & 33.35 & 480.2 & 2.5 \\
\hline 11 & 34.462 & 0.026 & 0.00000 & 3.546 & 56.80 & 96.91 & 33.4 & 480.8 & 3.9 \\
\hline 12 & 34.525 & 0.025 & 0.01044 & 3.976 & 59.00 & 96.55 & 33.34 & 480.0 & 3.0 \\
\hline 13 & 34.477 & 0.025 & 0.00000 & 3.118 & 62.83 & 97.28 & 33.54 & 482.5 & 2.7 \\
\hline 14 & 34.058 & 0.027 & 0.00000 & 1.788 & 67.39 & 98.4 & 33.51 & 482.2 & 2.7 \\
\hline 15 & 34.103 & 0.028 & 0.00000 & 1.581 & 69.44 & 98.58 & 33.62 & 483.6 & 4.6 \\
\hline 16 & 33.701 & 0.026 & 0.00000 & 0.809 & 73.23 & 99.24 & 33.45 & 481.4 & 1.6 \\
\hline 17 & 33.807 & 0.026 & 0.00000 & 0.726 & 76.31 & 99.32 & 33.58 & 483.0 & 2.0 \\
\hline 18 & 34.128 & 0.026 & 0.00000 & 1.843 & 78.69 & 98.36 & 33.57 & 482.9 & 2.2 \\
\hline 19 & 33.742 & 0.023 & 0.00778 & 1.58 & 81.84 & 98.57 & 33.26 & 479.0 & 2.4 \\
\hline 20 & 33.921 & 0.026 & 0.05392 & 1.562 & 83.39 & 98.6 & 33.45 & 481.4 & 2.1 \\
\hline 21 & 34.031 & 0.026 & 0.13242 & 1.878 & 84.41 & 98.35 & 33.47 & 481.7 & 3.2 \\
\hline 22 & 34.255 & 0.027 & 0.07780 & 2.209 & 86.16 & 98.07 & 33.59 & 483.2 & 2.2 \\
\hline 23 & 34.088 & 0.025 & 0.00000 & 1.579 & 89.48 & 98.59 & 33.61 & 483.4 & 2.0 \\
\hline
\end{tabular}




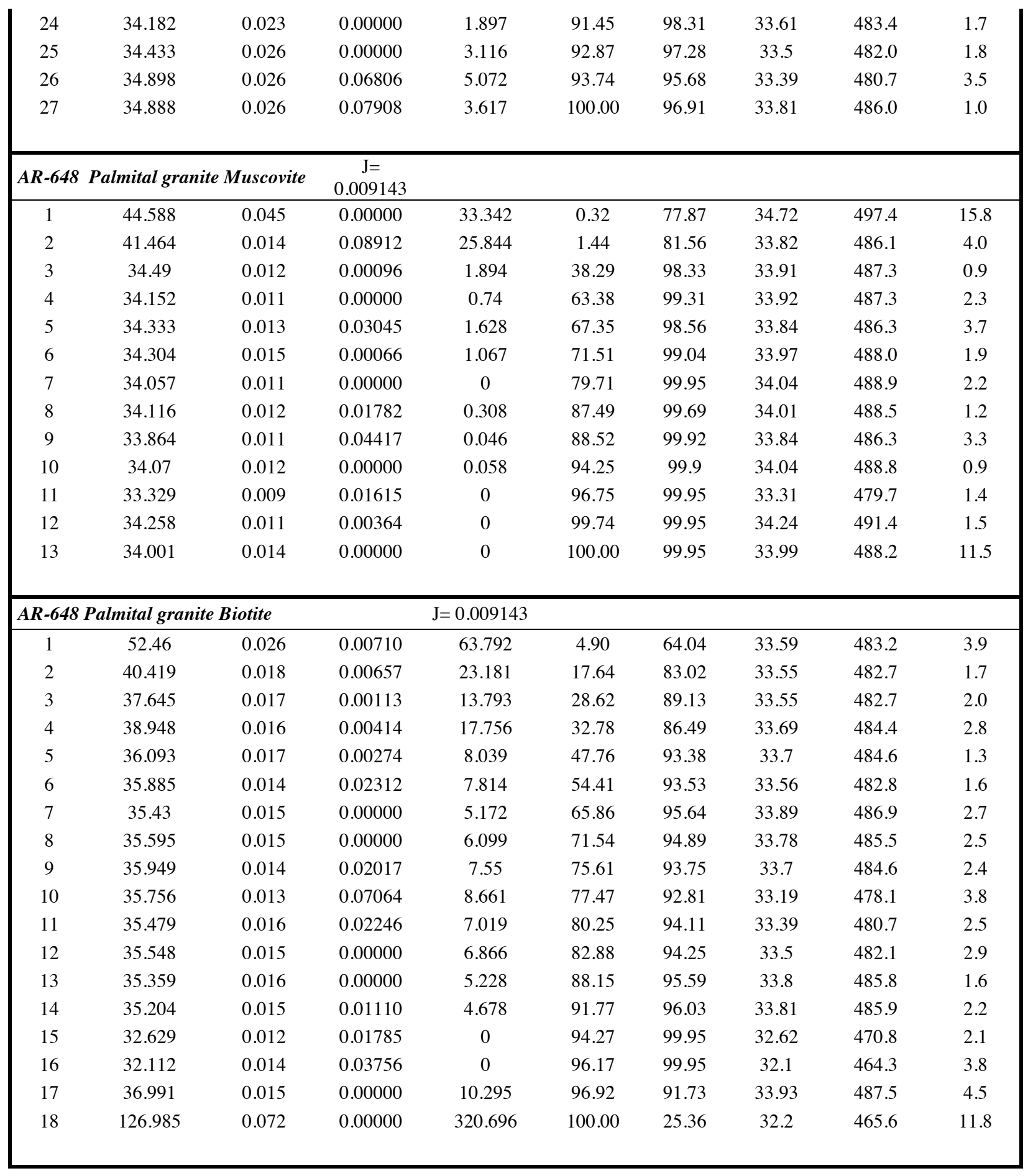




\section{Method:}

Samples from the Eastern Anatectic Unit were processed and analysed at the Geochronological Research Center of the University of São Paulo (Brazil). Separation and concentration consisted of hand crushing of centimetre-scale sample chips using steel pestle and mortar to reduce size to mm-scale, sieving for size fractions of \#250-500, and final magnetic purification through a isodynamic Frantz ${ }^{\circledR}$ separator. Biotite was loaded into a 21-pit aluminum disk along with the Fish Canyon sanidine standard (FCs) arranged in a cross-like geometry. Neutron-flux irradiation was performed in the cadmium lined in-core (CLICIT) facility at the Oregon State University TRIGA reactor for 14 hours. After radioactive cooling (approximately 4 weeks), each sample was loaded on a Cu-disk as multigrain aliquots containing two or three irradiated biotite flakes and progressively step-heated by a solid state $\mathrm{Nd}: \mathrm{YVO}_{4}(532 \mathrm{~nm})$ Verdi $6 \mathrm{~W}$ Coherent laser. Data reduction including correction for nuclear interferences, background (blank) and mass discrimination, as well J-value determination and graphical representation were made using the ArArCALC v2.5.2 software (Koppers, 2012). The ages were calculated relative to the age of $28.01 \pm 0.04$ Ma for the FCs standard (Phillips and Matchan, 2013a; Phillips and Matchan, 2013b), assuming the ${ }^{40} \mathrm{~K}$ decay constant of Steiger and Jäger (Steiger and Jäger, 1977). The J-factor value for this irradiation is $0.00406 \pm 0.00002$.

\section{Results:}

\begin{tabular}{|c|c|c|c|c|c|c|c|c|c|c|c|c|c|}
\hline Step & $\stackrel{{ }^{39} \mathrm{Ar}}{\text { released \% }}$ & ${ }^{40} \mathrm{Ar} /{ }^{39} \mathrm{Ar}$ & $1 \sigma$ & ${ }^{37} \mathrm{Ar} /{ }^{39} \mathrm{Ar}$ & $1 \sigma$ & ${ }^{36} \mathrm{Ar} /{ }^{39} \mathrm{Ar}$ & $1 \sigma$ & ${ }^{39} \mathrm{Ar}_{\mathrm{K}}(\%)$ & ${ }^{40} \mathrm{Ar} *(\%)$ & ${ }^{40} \mathrm{Ar}^{* / 39} \mathrm{Ar}_{\mathrm{K}}$ & $2 \sigma$ & $\begin{array}{c}\text { Age } \\
\text { (Ma) }\end{array}$ & $2 \sigma$ \\
\hline \multicolumn{14}{|c|}{ AR-535 Anatectic granite biotite } \\
\hline 1 & 2.1 & 75.104 & 0.426 & 0.0949 & 0.0321 & 0.0037 & 0.0071 & 2.09 & 98.53 & 74.00 & 4.30 & 475.06 & 24.30 \\
\hline 2 & 18.0 & 72.939 & 0.018 & 0.0183 & 0.0059 & -0.0006 & 0.0007 & 15.81 & 100.23 & 73.11 & 0.45 & 470.01 & 2.54 \\
\hline 3 & 42.8 & 71.218 & 0.091 & 0.0171 & 0.0022 & 0.0003 & 0.0003 & 24.87 & 99.88 & 71.13 & 0.26 & 458.80 & 1.49 \\
\hline 4 & 63.1 & 71.345 & 0.044 & 0.0118 & 0.0033 & 0.0012 & 0.0006 & 20.45 & 99.50 & 70.99 & 0.39 & 457.97 & 2.23 \\
\hline 5 & 76.3 & 71.988 & 0.118 & 0.0203 & 0.0057 & 0.0033 & 0.0010 & 13.12 & 98.65 & 71.02 & 0.64 & 458.14 & 3.67 \\
\hline 6 & 87.6 & 71.965 & 0.087 & 0.0785 & 0.0042 & 0.0008 & 0.0007 & 11.28 & 99.70 & 71.75 & 0.48 & 462.30 & 2.72 \\
\hline 7 & 91.2 & 73.069 & 0.295 & -0.1005 & 0.0072 & 0.0055 & 0.0016 & 3.70 & 97.75 & 71.42 & 1.11 & 460.44 & 6.30 \\
\hline 8 & 97.5 & 72.664 & 0.144 & -0.0329 & 0.0081 & 0.0027 & 0.0023 & 6.25 & 98.90 & 71.86 & 1.40 & 462.94 & 7.98 \\
\hline 9 & 99.1 & 75.197 & 0.942 & -0.0306 & 0.0213 & 0.0148 & 0.0063 & 1.67 & 94.14 & 70.79 & 4.17 & 456.83 & 23.78 \\
\hline 10 & 100.0 & 82.607 & 0.533 & -0.1886 & 0.0588 & 0.0009 & 0.0122 & 0.77 & 99.67 & 82.32 & 7.39 & 521.44 & 40.64 \\
\hline \multicolumn{14}{|c|}{ AR-664 Anatectic granite biotite } \\
\hline 1 & 2.8 & 74.623 & 0.162 & 0.0167 & 0.0195 & 0.0100 & 0.0034 & 2.74 & 95.98 & 71.63 & 2.04 & 461.60 & 11.59 \\
\hline 2 & 23.2 & 73.705 & 0.100 & 0.0305 & 0.0007 & -0.0020 & 0.0005 & 20.57 & 100.81 & 74.30 & 0.35 & 476.74 & 1.97 \\
\hline 3 & 42.6 & 74.270 & 0.041 & -0.0067 & 0.0049 & -0.0007 & 0.0009 & 19.21 & 100.27 & 74.47 & 0.54 & 477.71 & 3.03 \\
\hline 4 & 61.5 & 73.577 & 0.084 & 0.0019 & 0.0048 & 0.0008 & 0.0003 & 19.04 & 99.68 & 73.34 & 0.23 & 471.35 & 1.30 \\
\hline 5 & 74.3 & 73.410 & 0.062 & 0.0058 & 0.0020 & -0.0025 & 0.0010 & 12.68 & 101.02 & 74.16 & 0.64 & 475.97 & 3.60 \\
\hline 6 & 85.2 & 73.691 & 0.098 & -0.0301 & 0.0032 & 0.0012 & 0.0016 & 11.24 & 99.51 & 73.33 & 0.96 & 471.26 & 5.41 \\
\hline 7 & 95.4 & 74.157 & 0.092 & 0.0581 & 0.0035 & -0.0031 & 0.0009 & 9.94 & 101.24 & 75.08 & 0.58 & 481.15 & 3.24 \\
\hline 8 & 97.3 & 73.385 & 0.774 & -0.0296 & 0.0281 & -0.0071 & 0.0049 & 2.05 & 102.88 & 75.50 & 3.35 & 483.48 & 18.83 \\
\hline 9 & 99.6 & 78.937 & 0.837 & -0.1303 & 0.0543 & 0.0023 & 0.0083 & 2.10 & 99.12 & 78.23 & 5.23 & 498.79 & 29.13 \\
\hline 10 & 100.0 & 68.647 & 0.102 & -0.1451 & 0.0947 & 0.0889 & 0.0156 & 0.44 & 61.33 & 42.09 & 9.31 & 285.31 & 58.38 \\
\hline \multicolumn{14}{|c|}{ AR1133 Anatectic granite biotite } \\
\hline 1 & 2.0 & 68.546 & 0.747 & -0.0401 & 0.0538 & 0.0601 & 0.0021 & 1.85 & 73.83 & 50.60 & 1.62 & 337.89 & 9.85 \\
\hline 2 & 14.1 & 76.158 & 0.025 & -0.0042 & 0.0058 & 0.0021 & 0.0024 & 12.37 & 99.16 & 75.52 & 1.42 & 483.60 & 7.99 \\
\hline 3 & 32.7 & 75.626 & 0.023 & -0.0028 & 0.0024 & -0.0009 & 0.0007 & 18.45 & 100.34 & 75.88 & 0.43 & 485.65 & 2.41 \\
\hline 4 & 51.4 & 75.885 & 0.092 & -0.0048 & 0.0024 & -0.0025 & 0.0003 & 18.80 & 101.00 & 76.64 & 0.28 & 489.91 & 1.56 \\
\hline 5 & 71.8 & 75.560 & 0.031 & -0.0080 & 0.0008 & -0.0011 & 0.0007 & 19.26 & 100.41 & 75.87 & 0.43 & 485.59 & 2.41 \\
\hline 6 & 89.9 & 76.085 & 0.096 & 0.0030 & 0.0023 & 0.0001 & 0.0007 & 19.18 & 99.95 & 76.05 & 0.48 & 486.58 & 2.67 \\
\hline
\end{tabular}




\begin{tabular}{|c|c|c|c|c|c|c|c|c|c|c|c|c|c|}
\hline 7 & 92.0 & 76.922 & 0.539 & -0.0123 & 0.0164 & 0.0013 & 0.0057 & 2.09 & 99.49 & 76.53 & 3.57 & 489.26 & 20.02 \\
\hline 8 & 94.5 & 77.429 & 0.277 & 0.0212 & 0.0221 & -0.0021 & 0.0049 & 2.56 & 100.79 & 78.04 & 3.01 & 497.74 & 16.76 \\
\hline 9 & 95.1 & 96.414 & 1.689 & -0.0442 & 0.1504 & -0.0416 & 0.0288 & 0.47 & 112.86 & 108.81 & 17.61 & 661.62 & 89.66 \\
\hline 10 & 100.0 & 76.783 & 0.074 & -0.0160 & 0.0135 & 0.0044 & 0.0026 & 4.72 & 98.28 & 75.46 & 1.56 & 483.27 & 8.78 \\
\hline \multicolumn{14}{|c|}{$A R-1145$ Diatexite biotite } \\
\hline 1 & 3.8 & 76.081 & 0.461 & 0.0267 & 0.0152 & 0.0062 & 0.0045 & 3.76 & 97.58 & 74.24 & 2.84 & 476.40 & 15.99 \\
\hline 2 & 19.7 & 74.885 & 0.098 & 0.0021 & 0.0036 & 0.0010 & 0.0008 & 16.04 & 99.61 & 74.59 & 0.49 & 478.38 & 2.78 \\
\hline 3 & 41.7 & 74.068 & 0.056 & 0.0071 & 0.0018 & -0.0005 & 0.0008 & 21.89 & 100.20 & 74.22 & 0.47 & 476.27 & 2.66 \\
\hline 4 & 58.6 & 74.312 & 0.095 & 0.0352 & 0.0001 & 0.0008 & 0.0009 & 16.87 & 99.67 & 74.07 & 0.58 & 475.44 & 3.25 \\
\hline 5 & 74.1 & 74.438 & 0.092 & -0.0017 & 0.0032 & -0.0002 & 0.0002 & 15.51 & 100.06 & 74.49 & 0.22 & 477.79 & 1.23 \\
\hline 6 & 88.0 & 74.188 & 0.079 & -0.0054 & 0.0063 & 0.0006 & 0.0003 & 13.97 & 99.75 & 74.00 & 0.26 & 475.07 & 1.45 \\
\hline 7 & 94.9 & 74.099 & 0.070 & -0.0330 & 0.0026 & -0.0007 & 0.0024 & 6.67 & 100.29 & 74.31 & 1.46 & 476.81 & 8.26 \\
\hline 8 & 97.2 & 78.537 & 0.256 & 0.0831 & 0.0015 & 0.0071 & 0.0031 & 2.62 & 97.31 & 76.43 & 1.91 & 488.71 & 10.68 \\
\hline 9 & 99.1 & 75.991 & 0.233 & -0.0308 & 0.0168 & -0.0055 & 0.0056 & 1.92 & 102.16 & 77.63 & 3.37 & 495.42 & 18.82 \\
\hline 10 & 100.0 & 103.780 & 3.899 & -0.0479 & 0.2651 & -0.0895 & 0.0691 & 0.22 & 125.76 & 130.51 & 42.35 & 768.85 & 203.22 \\
\hline \multicolumn{14}{|c|}{ AR-1349 Metatexite biotite } \\
\hline 1 & 2.6 & 75.148 & 0.048 & 0.0038 & 0.0193 & 0.0088 & 0.0044 & 2.41 & 96.52 & 72.53 & 2.61 & 466.73 & 14.82 \\
\hline 2 & 18.7 & 73.699 & 0.043 & -0.0035 & 0.0039 & 0.0003 & 0.0007 & 16.17 & 99.86 & 73.60 & 0.45 & 472.77 & 2.57 \\
\hline 3 & 40.0 & 74.334 & 0.030 & -0.0001 & 0.0033 & 0.0006 & 0.0003 & 21.43 & 99.77 & 74.16 & 0.18 & 475.97 & 1.04 \\
\hline 4 & 57.9 & 73.908 & 0.031 & 0.0006 & 0.0036 & 0.0015 & 0.0008 & 17.85 & 99.41 & 73.47 & 0.48 & 472.07 & 2.73 \\
\hline 5 & 74.3 & 73.914 & 0.012 & -0.0028 & 0.0015 & -0.0012 & 0.0005 & 16.36 & 100.50 & 74.28 & 0.29 & 476.65 & 1.64 \\
\hline 6 & 86.4 & 74.232 & 0.069 & -0.0049 & 0.0037 & 0.0003 & 0.0009 & 12.17 & 99.87 & 74.13 & 0.58 & 475.81 & 3.27 \\
\hline 7 & 95.2 & 73.989 & 0.040 & 0.0236 & 0.0022 & -0.0006 & 0.0006 & 9.04 & 100.24 & 74.17 & 0.39 & 475.98 & 2.18 \\
\hline 8 & 97.6 & 73.159 & 0.180 & -0.0378 & 0.0181 & -0.0065 & 0.0038 & 2.19 & 102.65 & 75.09 & 2.30 & 481.21 & 12.97 \\
\hline 9 & 100.0 & 78.291 & 0.116 & -0.0526 & 0.0121 & 0.0012 & 0.0018 & 2.37 & 99.52 & 77.91 & 1.12 & 497.00 & 6.22 \\
\hline \multicolumn{14}{|c|}{ AR-1368 Anatectic granite biotite } \\
\hline 1 & 3.1 & 68.182 & 0.009 & -0.0421 & 0.0207 & -0.0045 & 0.0055 & 3.11 & 101.96 & 69.52 & 3.30 & 449.57 & 18.87 \\
\hline 2 & 22.3 & 71.413 & 0.029 & -0.0048 & 0.0052 & -0.0005 & 0.0011 & 19.35 & 100.20 & 71.56 & 0.69 & 461.21 & 3.92 \\
\hline 3 & 44.1 & 72.785 & 0.110 & -0.0071 & 0.0048 & -0.0005 & 0.0006 & 21.88 & 100.21 & 72.94 & 0.41 & 469.04 & 2.35 \\
\hline 4 & 58.8 & 72.960 & 0.067 & -0.0014 & 0.0039 & 0.0001 & 0.0009 & 14.26 & 99.98 & 72.94 & 0.56 & 469.08 & 3.18 \\
\hline 5 & 69.9 & 72.692 & 0.061 & -0.0072 & 0.0089 & -0.0033 & 0.0005 & 11.30 & 101.34 & 73.67 & 0.30 & 473.16 & 1.71 \\
\hline 6 & 79.9 & 73.675 & 0.053 & -0.0049 & 0.0073 & 0.0025 & 0.0007 & 9.95 & 99.00 & 72.94 & 0.40 & 469.06 & 2.29 \\
\hline 7 & 88.5 & 72.897 & 0.099 & 0.0083 & 0.0088 & 0.0034 & 0.0007 & 9.67 & 98.63 & 71.90 & 0.45 & 463.14 & 2.53 \\
\hline 8 & 95.2 & 73.578 & 0.007 & -0.0601 & 0.0050 & 0.0050 & 0.0019 & 5.59 & 97.95 & 72.07 & 1.11 & 464.11 & 6.28 \\
\hline 9 & 99.2 & 71.936 & 0.090 & -0.0225 & 0.0173 & 0.0015 & 0.0032 & 4.26 & 99.39 & 71.49 & 1.92 & 460.85 & 10.90 \\
\hline 10 & 100.0 & 72.199 & 0.996 & -0.1665 & 0.0926 & 0.0304 & 0.0163 & 0.63 & 87.41 & 63.10 & 9.86 & 412.45 & 57.65 \\
\hline
\end{tabular}

Koppers, A., 2012. ArArCALC v252: software for ${ }^{40} \mathrm{Ar} /{ }^{39} \mathrm{Ar}$ geochronology, http://www earthref.org. Phillips, D. and Matchan, E.L., 2013a. Ultra-high precision ${ }^{40} \mathrm{Ar} /{ }^{39} \mathrm{Ar}$ ages for Fish Canyon Tuff and Alder Creek Rhyolite sanidine: new dating standards required? Geochimica and Cosmochimica Acta 121, 229-239.

Steiger, R.H. and Jäger, E., 1977. Subcomission on geochronology: convention on the use of decay constants in geo- and cosmochronology. Earth and Planetary Science Letters 6, 359-362. 